\title{
Nanomaterials for the Removal of Heavy Metals from Wastewater
}

\author{
Jinyue Yang, Baohong Hou *, Jingkang Wang, Beiqian Tian, Jingtao Bi $\mathbb{D}$, Na Wang, Xin Li and \\ Xin Huang *iD
}

National Engineering Research Center of Industrial Crystallization Technology, School of Chemical Engineering and Technology, Tianjin University, Tianjin 300072, China; jyyang@tju.edu.cn (J.Y.); jkwang@tju.edu.cn (J.W.); beiqiantian@tju.edu.cn (B.T.); jingtaob@gmail.com (J.B.); wangna224@tju.edu.cn (N.W.); 2016207425@tju.edu.cn (X.L.)

* Correspondence: houbaohong@tju.edu.cn (B.H.); x_huang@tju.edu.cn (X.H.); Tel.: +86-22-27403200 (X.H.)

Received: 26 January 2019; Accepted: 7 March 2019; Published: 12 March 2019

\begin{abstract}
Removal of contaminants in wastewater, such as heavy metals, has become a severe problem in the world. Numerous technologies have been developed to deal with this problem. As an emerging technology, nanotechnology has been gaining increasing interest and many nanomaterials have been developed to remove heavy metals from polluted water, due to their excellent features resulting from the nanometer effect. In this work, novel nanomaterials, including carbon-based nanomaterials, zero-valent metal, metal-oxide based nanomaterials, and nanocomposites, and their applications for the removal of heavy metal ions from wastewater were systematically reviewed. Their efficiency, limitations, and advantages were compared and discussed. Furthermore, the promising perspective of nanomaterials in environmental applications was also discussed and potential directions for future work were suggested.
\end{abstract}

Keywords: nanomaterials; heavy metal; wastewater; carbon-based nanomaterials; zero-valent metal; metal oxide; nanocomposite

\section{Introduction}

Water is one of the most important natural resources in the world, which is vital for the survival of all living beings and the development of humans. Along with the acceleration of industrialization and urbanization, the consumption of water is increasing rapidly and water scarcity problem has become an important constraint for economic development. In the meantime, water contamination, especially heavy metals pollution inside water, has become a global environmental issue. Heavy metals could be released into water mainly through the mining, electroplating, metallurgy, chemical plants, agriculture and household wastewater etc. Heavy metals such as $\mathrm{Pb}, \mathrm{Zn}, \mathrm{Cu}, \mathrm{Hg}$, etc. could pose a severe threat to human's health because they can be accumulated biologically in the food chain [1]. For example, heavy metals could cause damages to the kidneys, mental and central nervous functions, lungs, and other organs [2-4]. Moreover, heavy metals can also exert adverse effects on the environment and other ecological receptors, as they cannot be degraded by microorganisms once they are released into the environment, on the contrary, they will accumulate through the food chain. Heavy metals are highly toxic [5], most of which are even reported to be carcinogenic [6]. Therefore, the removal of heavy metals from water is of great importance and has drawn tremendous attention. Up till now, numerous technologies have been developed to solve this problem, including chemical precipitation [7], ion exchange [8], adsorption [9], membrane filtration [10], electrochemical treatment [11], and so on. Besides, it is often the case that different techniques are combined for a better removal result $[12,13]$. Among the techniques discussed above, adsorption is one of the most extensively used techniques due 
to its low cost and simple operation. In recent years, porous metal-organic framework (MOF) materials have also shown their great superiority in eliminating hazardous substances from the environment due to their large/tunable porosity, pore functionality, and various pore structures etc. [14]. Ricco et al. has synthesized a magnetic nanocomposite based on aluminum MOF (MIL-53) and the composite exhibited excellent removal capacity towards $\mathrm{Pb}$ (II) with the value of $492.4 \mathrm{mg} \cdot \mathrm{g}^{-1}$ [15]. Nowadays, nanomaterials have also provided a promising approach to removing heavy metals from wastewater.

Over the past decades, nanomaterials have gained a lot of attention. Numerous nanomaterials have been exploited in many fields, including electron devices [16], health care [17], energy [18], etc. The past decades have also witnessed the increasing applications of nanomaterials in the environmental protection field [19]. In general, nanomaterials are materials whose external dimensions are in the nanoscale (usually 1-100 nm) or those who have a nanoscale internal structure/surface [20]. Under the nanoscale, nanomaterials often exhibit some special properties, such as a surface effect, small size effect, quantum effect, and macro quantum tunnel effect [21]. These properties contribute to their extraordinary adsorption capacity and reactivity, both of which are favorable for the removal of heavy metal ions. So far, tremendous studies on nanomaterials have been carried out to investigate their applications on heavy metal water treatment and they have exhibited great potential as a promising alternative to adsorbing heavy metals from wastewater [22,23].

Based on the above background, this work reviews the latest development of nanomaterials which are used to remove heavy metals from wastewater. There have been some reviews regarding the water treatment of nanomaterials. For example, Marija et al. has summarized the graphene oxide nanocomposites for removing heavy metals [24]. Ihsanullah et al. has given a systematic review on the adsorption applications for heavy metals of carbon nanotubes [25]. Different parameters that could influence the adsorption behaviors have been discussed in this review. The current challenges and perspectives of carbon nanotubes were also well illustrated in this review. Hua et al. have summarized nanosized metal oxides for removing heavy metals [26]. However, these reviews were all focused on a single kind of nanomaterial, some of which were also outdated and missed the latest developments of nanomaterials for heavy metal treatment. In other reviews covering different kinds of nanomaterials, such as in the work of Wang et al., some nanomaterials for heavy metal removal including the carbon-based nanomaterials, metal/metal oxides nanoparticles, and polymer-supported adsorbents were simply reviewed [27]. These nanomaterials have shown their great potential for wastewater treatment due to their high adsorption capacity and selectivity, although this review was not that comprehensive. In Lee et al.'s review, metal oxide nanoparticles, carbon nanomaterials, and nanocomposites were discussed [28]. The preparation and characterization methods of these nanomaterials were introduced in this article. Still, the nanomaterials demonstrated in this review were incomprehensive, although this review has given a brief introduction on the measuring techniques of heavy metals. In this work, a systematic and comprehensive overview of the following nanomaterials: Carbon-based nanomaterials, zero-valent metal nanomaterials, metal oxide materials and nanocomposites, are presented. Some updated literatures related to the topic are especially presented here. The perspective of nanomaterials in heavy metal water treatment and the suggestion for future research direction are also discussed.

\section{Adsorption Isotherms and Kinetics}

In order to better illustrate the adsorption behaviors of the following nanomaterials, some models of adsorption isotherms and kinetics are briefly introduced in this chapter.

\subsection{Adsorption Isotherms}

Adsorption isotherms are very helpful for analyzing the adsorption capacities of the adsorbents. When the adsorption equilibrium is established, the relation between the amount of the adsorbates on the adsorbents and the equilibrium concentrations of the adsorbates under constant temperatures is called the adsorption isotherm [29]. There are various kinds of models for determining the adsorption 
isotherms, such as the Langmuir, Freundlich, Dubinin-Radushkevich, and Sips model etc. [30-33]. The Langmuir and Freundlich models are most extensively used and intensively discussed in this chapter.

\subsubsection{Langmuir Model}

According to the Langmuir model, adsorption takes place uniformly on the active sites of the adsorbents, and once the adsorptive sites are occupied by the adsorbates, there will be no more adsorption behaviors on these sites [34]. The Langmuir model supposes that all the adsorption active sites have the same binding energy and each site is only able to bind a single adsorbate [35]. The linear form of the Langmuir model is expressed as [36]:

$$
\frac{C_{e}}{q_{e}}=\frac{1}{b q_{m}}+\frac{C_{e}}{q_{m}}
$$

where $q_{e}$ is the equilibrium adsorption capacity of the adsorbent $\left(\mathrm{mg} \cdot \mathrm{g}^{-1}\right), C_{e}$ is the equilibrium concentration of the adsorbate $\left(\mathrm{mg} \cdot \mathrm{L}^{-1}\right), q_{m}$ is the saturated single layer adsorption capacity $\left(\mathrm{mg} \cdot \mathrm{g}^{-1}\right)$, and $b$ is the adsorption equilibrium constant.

\subsubsection{Freundlich Model}

The Freundlich isotherm model is another empirical equation which can be used to describe the non-ideal sorption behaviors [37]. The Freundlich model was proven to be consistent with the exponential distribution of active centers, characteristic of heterogeneous surfaces [34]. Unlike the Langmuir model, the Freundlich model is based on the multilayer adsorption and its linear form can be expressed as [38]:

$$
\ln q_{e}=\left(\frac{1}{n}\right) \ln C_{e}+\ln K_{F}
$$

where $q_{e}$ is the equilibrium adsorption capacity of the adsorbent $\left(\mathrm{mg} \cdot \mathrm{g}^{-1}\right), C_{e}$ is the equilibrium concentration of the adsorbate $\left(\mathrm{mg} \cdot \mathrm{L}^{-1}\right), K_{F}$ is the Freundlich constant (index of adsorption capacity), and $n$ is also a Freundlich constant (index of adsorption intensity or surface heterogeneity).

\subsubsection{Sips Model}

The Sips isotherm is a hybrid model of the Langmuir and the Freundlich isotherms [33]. The Sips model is used to predict the heterogeneous adsorption systems and can avoid the limitation of the rising adsorbate concentration associated with the Freundlich isotherm model [39,40]. At low adsorbate concentrations, the Sips isotherm effectively reduces to the Freundlich isotherm. While at high adsorbate concentrations, the Sips model predicts a monolayer sorption capacity characteristic of the Langmuir isotherm [41]. The Sips model could be expressed as [42]:

$$
q_{e}=\frac{q_{m}\left(K_{S} C_{e}\right)^{n_{S}}}{1+\left(K_{S} C_{e}\right)^{n_{S}}}
$$

where $q_{e}$ is the equilibrium adsorption capacity of the adsorbent $\left(\mathrm{mg} \cdot \mathrm{g}^{-1}\right), C_{e}$ is the equilibrium concentration of the adsorbate $\left(\mathrm{mg} \cdot \mathrm{L}^{-1}\right), q_{m}$ is the Sips maximum adsorption capacity $\left(\mathrm{mg} \cdot \mathrm{g}^{-1}\right), K_{S}$ $\left(\mathrm{L} \cdot \mathrm{mg}^{-1}\right)$ is the Langmuir equilibrium constant and $n_{S}$ is comparable to the Freundlich heterogeneity factor $n_{F}\left(n_{S}=1 / n_{F}\right)$.

\subsection{Adsorption Kinetics}

The determination of kinetics is vital for the design of adsorption systems and the reaction rate controlling step as the chemical reaction occurs [43]. Adsorption kinetics describe the relations between the amount of adsorbates adsorbed on the adsorbents $\left(q_{t}\right)$ and the contact time $(t)$. The commonly used adsorption kinetics include the pseudo-first-order and pseudo-second-order kinetic 
model. The pseudo-first order model describes the adsorption of liquid-solid phase systems based on the adsorption capacity [44], while the pseudo-second order model is based on the adsorption capacity of the solid phases.

For the pseudo-first order model of Lagrange, it can be generally expressed as follows [45]:

$$
\frac{\mathrm{d} q_{t}}{d t}=K\left(q_{e}-q_{t}\right)
$$

The integral form of this equation is given as follows:

$$
\log \left(q_{e}-q_{t}\right)=\log q_{e}-\frac{k_{1}}{2.303} t
$$

where $q_{e}$ is the equilibrium adsorption capacity of the adsorbent $\left(\mathrm{mg} \cdot \mathrm{g}^{-1}\right), q_{t}$ is the adsorption capacity $\left(\mathrm{mg} \cdot \mathrm{g}^{-1}\right)$ when the contact time is $t, K$ and $k_{1}$ are the rate constants of the pseudo first-order adsorption model.

The pseudo-second-order model can be expressed as follows [43]:

$$
\frac{\mathrm{d} q_{t}}{d t}=k_{2}\left(q_{e}-q_{t}\right)^{2}
$$

The integral form of this equation is given as follows:

$$
\frac{t}{q_{t}}=\frac{1}{k_{2} q_{e}{ }^{2}}+\frac{1}{q_{e}} t
$$

where $q_{e}$ is the equilibrium adsorption capacity of the adsorbent $\left(\mathrm{mg} \cdot \mathrm{g}^{-1}\right), q_{t}$ is the adsorption capacity $\left(\mathrm{mg} \cdot \mathrm{g}^{-1}\right)$ when the contact time is $t, k_{2}$ is the rate constant of the pseudo second-order adsorption model.

\section{Nanomaterials for Removing Heavy Metals}

\subsection{Carbon-Based Nanomaterials}

Carbon-based nanomaterials were initially applied in the electronics industry owing to their extraordinary thermal and electrical properties [46]. Nevertheless, some other exceptional properties they exhibited, such as a large surface area, ease of chemical or physical modification, ability of removing both organic, and inorganic pollutants have made carbon-based nanomaterials potential alternatives for treating wastewater [47]. Here, two major carbon-based nanomaterials are mainly presented-carbon nanotubes-based and graphene-based nanomaterials.

\subsubsection{Carbon Nanotubes}

Carbon nanotubes (CNTs) have been extensively investigated during the last decades and they were reported to exhibit many exceptional properties, including optical, electronic, vibrational, mechanical and thermal properties [48]. There have been numerous reports on their applications for the removal of heavy metals from wastewater [49]. Carbon nanotubes, basically divided into single-walled CNTs (SWCNTs) and multi-walled CNTs (MWCNTs) [50], are one kind of carbon-based materials whose lengths are about hundreds to thousands of nanometers and diameters are about 1-3 nm [51]. Carbon nanotubes have many superiorities in treating heavy metal wastewater, mainly including the large specific surface area, high adsorption capacity, and fast adsorption kinetics [52]. Carbon nanotubes were reported to have excellent adsorption effects towards Mn (VII), Tl (I), Cu (II), $\mathrm{Pb}$ (II), Cr (VI), etc. [53-57]. The possible adsorption active sites of carbon nanotubes are mainly comprised of outside surface, interstitial channels, internal sites, and external groove sites. Figure 1 
has given an illustration of adsorption sites based on the adsorption of single-walled carbon nanotubes (SWNTs) bundles [58].

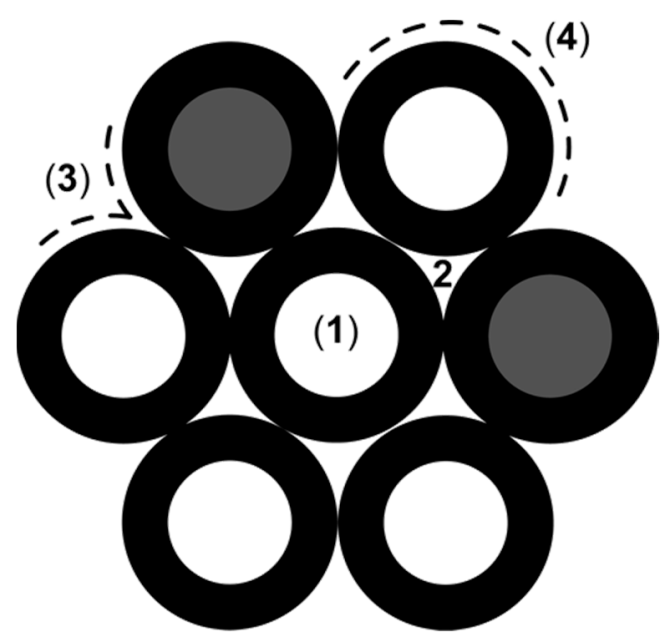

Figure 1. Different adsorption sites on a homogeneous bundle of partially open-ended single-walled carbon nanotubes (SWNTs): (1) Internal, (2) interstitial channel, (3) external groove site, and (4) external surface. Reproduced with permission from [58]. Copyright American Chemical Society, 2006.

To improve the adsorption capacity of CNTs towards heavy metals, functional groups, such as $-\mathrm{COOH},-\mathrm{NH}_{2},-\mathrm{OH}$, etc. are commonly introduced onto the surface of CNTs by means of chemical modification, heat treatment or endohedral filling [59]. For example, it was reported that oxidants such as $\mathrm{KMnO}_{4}, \mathrm{HNO}_{3}, \mathrm{H}_{2} \mathrm{SO}_{4}$, and $\mathrm{NaOCl}$ could improve the adsorption capacity remarkably by modifying the surface of CNTs [60]. Mohamed et al. reported the removal of Hg (II) by employing a functionalized-CNTs absorbent [61]. Allyl triphenyl phosphonium bromide and glycerol, which were used to form deep eutectic solvent (DET), were sonicated with pre-oxidized CNTs to prepare the new functionalized CNTs. The batch adsorption experiment results showed that the optimal condition was $\mathrm{pH}=5.5$ and the contact time was $28 \mathrm{~min}$. The corresponding maximum adsorption capacity for $\mathrm{Hg}$ (II) was determined to be $186.97 \mathrm{mg} \cdot \mathrm{g}^{-1}$ by using the Freundlich isotherm model and the adsorption process followed the pseudo-second-order kinetics. $\mathrm{Xu}$ et al. have given a thorough review on functionalized carbon nanotubes for adsorbing heavy metals from wastewater, covering the preparation, application, and mechanism of modified CNTs [62]. Carbon nanotubes could also be combined with other supports to make better nanocomposites. For example, Zhan et al. prepared a novel magnetic amino-functionalized $\mathrm{Fe}_{3} \mathrm{O}_{4}$ / carboxylic multi-walled CNTs hybrid by using a one-pot solvothermal method [63]. The novel CNTs-based nanocomposite showed an extremely high separation efficiency towards $\mathrm{Cu}$ (II) in batch adsorption tests, which resulted from the synergistic effect between the CNTs and the amino groups. The maximum adsorption capacity towards Cu (II) was calculated to be $30.49 \mathrm{mg} \cdot \mathrm{g}^{-1}$ according to the Langmuir model. Moreover, the adsorbent could be separated from the wastewater with the aid of an external magnetic field.

Although using CNTs to remove heavy metals from wastewater has many advantages, it still has a few drawbacks in many aspects. Firstly, the high costs of CNTs hinder their commercial use. A lot of work needs to be done to develop both effective and cost-saving CNTs. Moreover, it is usually difficult to separate CNTs from wastewater after the adsorption and this would increase the treatment costs and the risk of secondary pollution. Finally, the toxicological study of CNTs is also in high demand [59].

\subsubsection{Graphene Nanomaterials}

Graphene, as the first 2D atomic crystal available to us, is another important carbon-based nanomaterial which can also be used to remove heavy metals from wastewater. It owns many extraordinary properties, such as mechanical strength, stiffness and elasticity, electrical and thermal 
conductivity and so on [64], contributing to its extensive applications in many aspects. Besides, graphene oxide (GO) and reduced graphene oxide (RGO) are two kinds of graphene-based nanomaterials which can also be used to remove heavy metals from wastewater. GO is the oxidation product of graphene and it contains miscellaneous oxygen-containing functional groups, such as hydroxyl, carboxyl, epoxide and carbonyl functional groups, which make it possible to remove heavy metals [65]. RGO, the reduction product of GO, commonly has more defects than the pristine graphene and is more easily to be modified by functional groups, such as $-\mathrm{OH},-\mathrm{COOH}$, etc. [66]. Structure diagrams of some graphene-derived materials are given in Figure 2 [67]. The mechanism for these graphene-based nanomaterials to remove heavy metals lies in their large specific surface areas and some other extraordinary properties, such as ample functional groups, e.g., $-\mathrm{CH}(\mathrm{O}) \mathrm{CH}-,-\mathrm{OH}$, and - $\mathrm{COOH}$ etc., high negative charge density and highly hydrophilic characteristics [68].

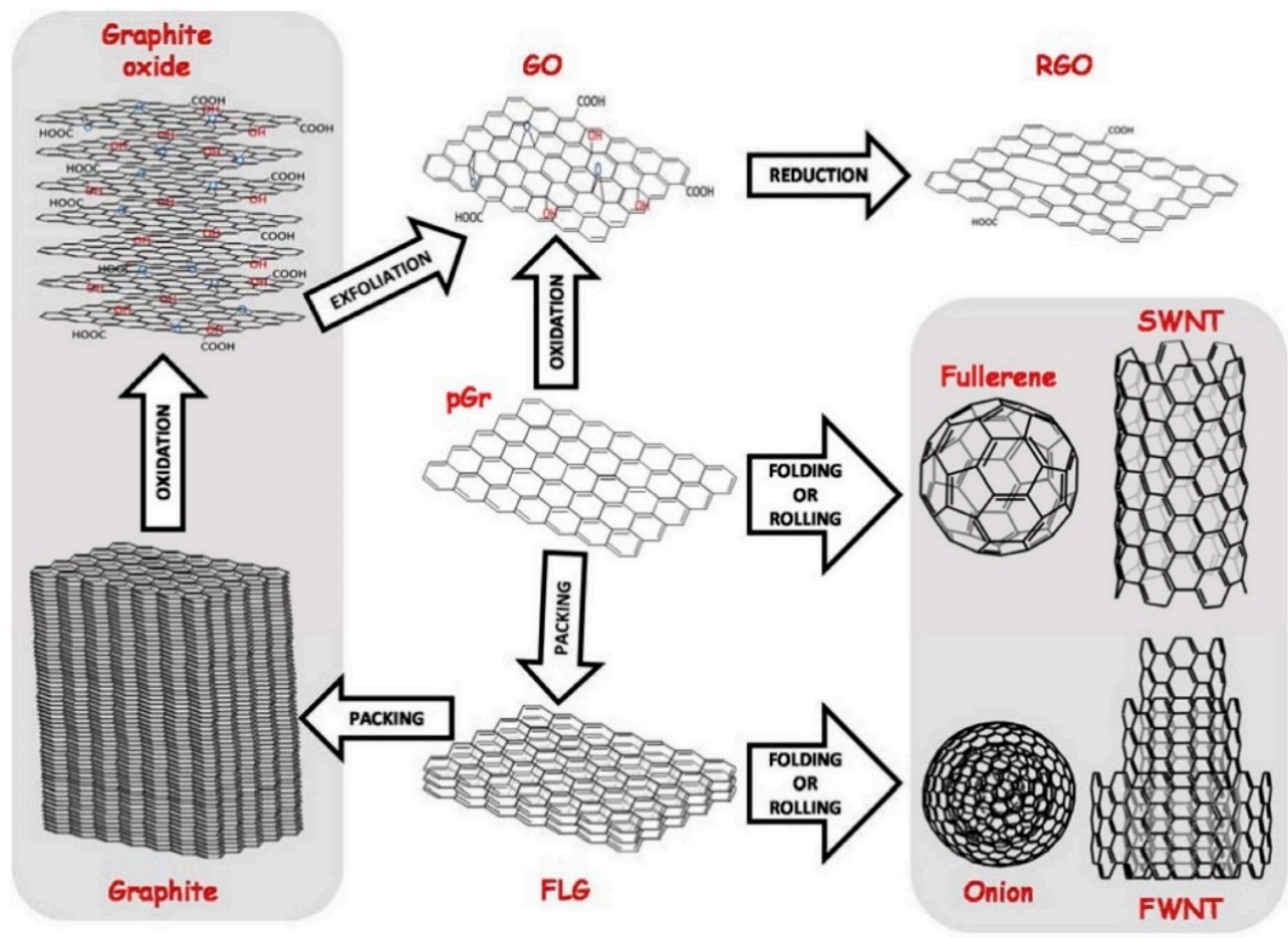

Figure 2. Several materials derived from the two-dimensional structure of graphene. Grey area indicates that these nanoallotropes are not included in graphene-family nanomaterials (GFNs), but constitute separated families. Reproduced with permission from [67]. Copyright Elsevier, 2017.

Graphene and GO/RGO-based materials have been extensively reported to remove heavy metals from wastewater. For example, Wang et al. studied different factors on the adsorption performance of $\mathrm{GO}$ for the removal of heavy metals in batch tests, including $\mathrm{pH}$, the dosage of the adsorbent, contact time, temperature, and coexisting ions [69]. The results showed that the adsorption process fitted the Langmuir isotherm and pseudo-second-order kinetic model well and the maximum adsorption capacity of $\mathrm{Zn}$ (II) was up to $246 \mathrm{mg} \cdot \mathrm{g}^{-1}$, indicating that GO was an effective adsorbent for $\mathrm{Zn}$ (II). Zhao et al. synthesized few-layered graphene oxide nanosheets by using a modified Hummers method and used them to adsorb Cd (II) and Co (II) in water by the batch method [70]. It indicated that the adsorption effect was strongly influenced by $\mathrm{pH}$ and the presence of humic acid in an aqueous solution could reduce the adsorption of $\mathrm{Cd}$ (II) and Co (II). The maximum adsorption capacities of Cd (II) and Co (II) onto GO were 106.3 and $68.2 \mathrm{mg} \cdot \mathrm{g}^{-1}$ respectively. The thermodynamic parameters of this 
adsorption process were also calculated and the results suggested that $\mathrm{Cd}$ (II) and Co (II) adsorptions on GO nanosheets were endothermic and spontaneous.

Moreover, there is an increasing number of reports on the graphene-based nanocomposites which are used to remove heavy metals from water. Some of the graphene-based nanocomposites are summarized in Table 1. As GO is well dispersed in water, it is difficult to separate it from the aqueous solution. Recently, Arshad et al. synthesized a novel graphene-modified absorbent which can solve this problem [71]. First, calcium alginate (CA) beads were embedded into the graphene oxide and then were further reduced by polyethylenimine to increase the adsorption capacity towards heavy metals. The adsorption experiment was carried out batch-wise in a shaker bath. The highest adsorption capacities of this GO-based nanocomposite towards $\mathrm{Pb}$ (II), $\mathrm{Hg}$ (II), and Cd (II) were 602, 374, $181 \mathrm{mg} \cdot \mathrm{g}^{-1}$ respectively according to the Langmuir isotherm, indicating a high superiority material for removing these three ions. The adsorption kinetics were found to follow the pseudo-second-order kinetics and the adsorption thermodynamic parameters indicated that the adsorption process could be attributed to physicochemical adsorption. The functionalized beads reduced by polyethylenimine exhibited a higher adsorption ability compared with the non-functionalized beads as a result of synergetic effect. Moreover, the reusability of the adsorbent was also studied and the results showed that the removal efficiency for $\mathrm{Pb}$ (II) remained at $75-80 \%$ even after five cycles. Vilela et al. built novel graphene oxide-based microbots (GOx-microbots) which could serve as self-propelled systems for capturing, transferring, and removing heavy metals [72]. GO, Ni, and Pt composed the structure of microbots. The results indicated that the mobile GOx-microbots could remove $\mathrm{Pb}$ (II) ten times more efficiently than that of nonmobile GOx-microbots and the concentration of $\mathrm{Pb}$ (II) could be reduced from $1000 \mathrm{ppb}$ down to below $50 \mathrm{ppb}$ in $60 \mathrm{~min}$ after the treatment. The GOx-microbots could also be reused after removing the lead from the surface of the microbots.

Table 1. Graphene-based nanocomposites for heavy metals removal.

\begin{tabular}{|c|c|c|c|c|}
\hline No. & Adsorbent & Adsorbate & $\begin{array}{l}\text { Maximum Adsorption } \\
\text { Capacity }\left(\mathrm{mg} \cdot \mathrm{g}^{-1}\right)\end{array}$ & Refs. \\
\hline 1 & $\begin{array}{l}\text { Functionalized } \\
\text { GOCA beads }\end{array}$ & $\mathrm{Pb}$ (II), $\mathrm{Hg}$ (II) and Cd (II) & 602,374 and 181 & [71] \\
\hline 2 & GO/PAMAMs & $\begin{array}{c}\mathrm{Pb}(\mathrm{II}), \mathrm{Cd}(\mathrm{II}), \mathrm{Cu}(\mathrm{II}) \text { and } \\
\mathrm{Mn} \text { (II) }\end{array}$ & $568.18,253.81,68.68$ and 18.29 & [73] \\
\hline 3 & CS/GO-SH & $\mathrm{Cu}(\mathrm{II}), \mathrm{Pb}$ (II) and Cd (II) & 425,447 and 177 & [74] \\
\hline 4 & MMSP-GO & $\mathrm{Pb}(\mathrm{II})$ and $\mathrm{Cd}(\mathrm{II})$ & 333 and 167 & [75] \\
\hline 5 & PVK-GO & $\mathrm{Pb}(\mathrm{II})$ & 887.98 & [76] \\
\hline 6 & $\mathrm{MnFe}_{2} \mathrm{O}_{4} / \mathrm{GO}$ & $\mathrm{Pb}$ (II), As (III) and As (V) & 673,146 and 207 & [77] \\
\hline 7 & EDTA-mGO & $\mathrm{Pb}$ (II), $\mathrm{Hg}$ (II) and $\mathrm{Cu}(\mathrm{II})$ & $508.4,268.4$ and 301.2 & [78] \\
\hline 8 & GO/L-Trp & $\mathrm{Cu}(\mathrm{II})$ and $\mathrm{Pb}$ (II) & 588 and 222 & [79] \\
\hline 9 & PAH-GO & $\mathrm{Cu}(\mathrm{II})$ & 349.04 & [80] \\
\hline 10 & GO- $\alpha$ CD-PPY NC & $\mathrm{Cr}(\mathrm{VI})$ & 666.67 & [81] \\
\hline 11 & $\mathrm{RGO} / \mathrm{NiO}$ & $\mathrm{Cr}(\mathrm{VI})$ & 198 & [82] \\
\hline 12 & PAS-GO & $\mathrm{U}(\mathrm{VI})$ and Eu (III) & 310.63 and 243.90 & [83] \\
\hline 13 & Chitosan/GO & $\mathrm{Pb}$ (II), $\mathrm{Cu}$ (II) and $\mathrm{Cr}(\mathrm{VI})$ & $461.3,423.8$ and 310.4 & [84] \\
\hline
\end{tabular}

However, most studies on graphene-based nanomaterials are at a preliminary stage of research, and research on the practical application of these materials in industrial wastewater treatment are still lacking, especially for actual wastewater containing multiple pollutants. Besides, the recycle and reuse of graphene-based nanomaterials also demand further investigation from an economic perspective [68].

\subsection{Silica-Based Nanomaterials}

Silica-based nanomaterials are another kind of important nanomaterial for removing heavy metals due to their properties, such as non-toxicity and excellent surface characteristics [85]. Nanosilica can 
be surface modified by groups like $-\mathrm{NH}_{2},-\mathrm{SH}$, etc., or serve as the support of nanocomposites. For example, Kotsyuda et al. synthesized silica nanospheres which were biofunctionalized by 3-aminopropyl and phenyl groups and investigated their removal effects towards $\mathrm{Cu}$ (II) and cationic thiazine dye in static mode [86]. The results indicated that the functionalized silica nanospheres possessed enhanced adsorption capacities towards $\mathrm{Cu}$ (II) and methylene blue compared with the amino functionalized nanosilica. The adsorption capacity of biofunctionalized nanosilica towards methylene blue was almost twice the value of similar amino silica nanoparticles. This modified nanomaterial also exhibited a decent antibacterial activity. Najafi et al. has investigated the removal effects for $\mathrm{Cd}$ (II), $\mathrm{Ni}$ (II), and $\mathrm{Pb}$ (II) in a batch mode by employing three silica-based nanomaterials, including the amino functionalized silica gel $\left(\mathrm{NH}_{2}-\mathrm{SG}\right)$, amino functionalized silica nano hollow sphere ( $\mathrm{NH}_{2}$-SNHS) and non-functionalized silica nano hollow sphere (SNHS) [87]. The result indicated that the adsorption capacities of these three nanomaterials followed the order: $\mathrm{NH}_{2}-\mathrm{SNHS}_{>} \mathrm{NH}_{2}-\mathrm{SG}>$ SNHS and the trend of metal adsorption was $\mathrm{Pb}$ (II) $>\mathrm{Cd}$ (II) $>\mathrm{Ni}$ (II). The maximum adsorption capacities for $\mathrm{Pb}$ (II), Cd (II), and Ni (II) by using $\mathrm{NH}_{2}-\mathrm{SNHS}$ were 96.79, 40.73, and $31.29 \mathrm{mg} \cdot \mathrm{g}^{-1}$ respectively. The adsorption isotherms were found to be correlated with the Langmuir-Freundlich (Sips) isotherm well and the kinetic data fitted the pseudo-second-order well. Besides the surface modification, silica has also been extensively reported to prepare the nanocomposites, among which the magnetic silica materials have received a lot of attention. Pogorilyi et al. has successfully coated the magnetite particles with silica layers by means of the Stöber reaction and showed its application potential in a broad industrial scale [88]. Some of the magnetic silica materials will be discussed in a later chapter. In a study carried out by Mahmoud et al., nanopolyaniline and crosslinked nanopolyaniline were immobilized onto the nanosilica to make nanocomposites, Sil-Phy-NPANI and Sil-Phy-CrossNPANI [85]. The adsorption effects of Sil-Phy-NPANI and Sil-Phy-CrossNPANI towards $\mathrm{Cu}$ (II), Cd (II), $\mathrm{Hg}$ (II), and $\mathrm{Pb}$ (II) were compared by using a batch technique. The highest adsorption capacities of Sil-Phy-NPANI for Cu (II), Cd (II), Hg (II), and Pb (II) were 1700, 800, 600, and $900 \mu \mathrm{mol} \cdot \mathrm{g}^{-1}$ respectively, while the adsorption capacities of Sil-Phy-CrossNPANI for these four ions were $1650,1050,1350$, and $1450 \mu \mathrm{mol} \cdot \mathrm{g}^{-1}$ respectively by calculation from Langmuir isotherm. The results indicated that Sil-Phy-CrossNPANI could serve as an efficient adsorbent for Cd (II), Hg (II), and $\mathrm{Pb}(\mathrm{II})$.

\subsection{Zero-Valent Metal-Based Nanomaterials}

Zero-valent metal nanoparticles have exhibited their potential in water treatment and remediation in recent years. For example, Ag nanoparticles have been used to disinfect wastewater due to their antimicrobial ability [89]. Nanosized zero-valent zinc was reported to have an excellent degradation ability towards dioxins [90]. As for the heavy metal ions treatment, zero-valent iron was most extensively investigated and mainly discussed in this part. Moreover, some other nanosized noble metals were also discussed here.

\subsubsection{Zero-Valent Iron}

Nanoscale zero valent iron (nZVI) is a composite consisting of Fe (0) and ferric oxide coating (Figure 3) [91]. It has received increased attention as a novel adsorbent to treat various kinds of heavy metals, such as $\mathrm{Hg}$ (II), Cr (VI), Cu (II), Ni (II), Cd (II), etc. since it came out [92-94]. Basically, Fe (0) provides the reducing ability while the ferric oxide shell offers the sites of reactive and electrostatic interaction with heavy metals. Besides, the particle size of nZVI is controllable and there are abundant reactive sites on the surface [95]. The high reducing capacity and large specific surface area contribute to the superior performance of nZVI in removing heavy metals from wastewater [96]. 


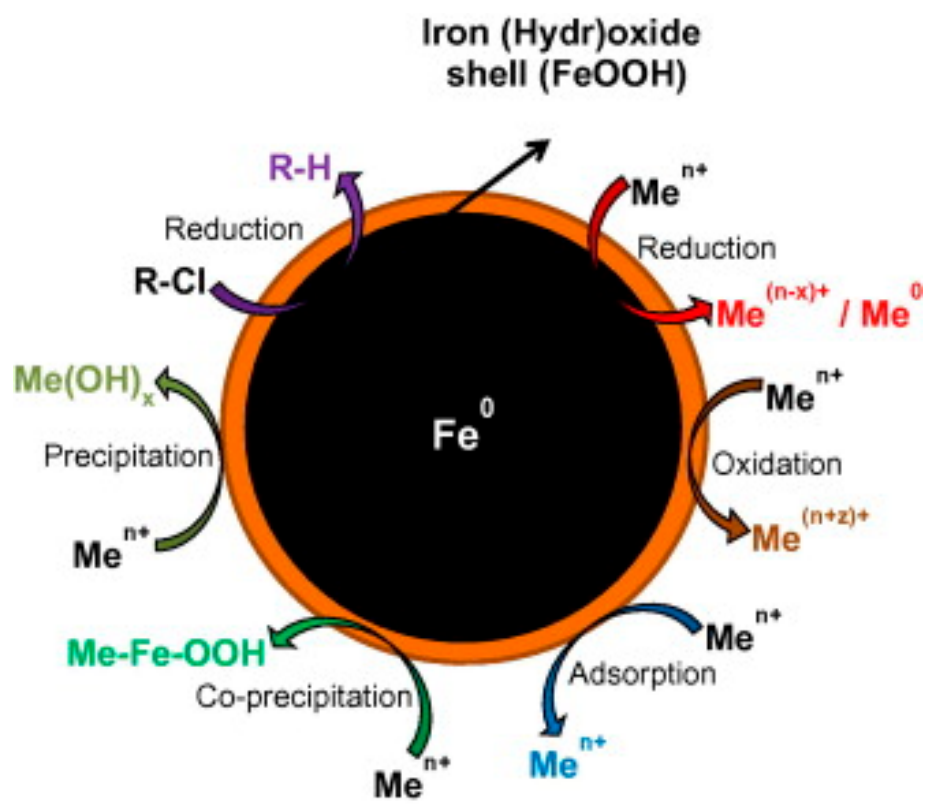

Figure 3. Core-shell structure of nanoscale zero valent iron (nZVI) depicting various mechanisms for the removal of metals and chlorinated compounds. Reproduced with permission from [91]. Copyright Elsevier, 2013.

It is worth noting that the removal mechanism of nZVI for different heavy metals could vary according to the standard potential $\mathrm{E}^{0}$ of the heavy metals [96]. For example, for $\mathrm{Pb}$ (II), whose $\mathrm{E}^{0}$ is slightly more positive than that of Fe (II), the removal mechanism was mainly comprised of reduction and sorption, which can be expressed as follows [97]:

$$
\begin{gathered}
\text { Reduction }: \equiv \mathrm{Fe}^{0}+\mathrm{M}^{2+} \rightarrow \equiv \mathrm{Fe}^{2+}+\mathrm{M}^{0} \\
\text { Sorption }: \equiv \mathrm{FeOOH}+\mathrm{M}^{2+} \rightarrow \equiv \mathrm{FeOOM}^{+}+\mathrm{H}^{+}
\end{gathered}
$$

While for heavy metal ions such as $\mathrm{Cr}(\mathrm{VI})$ whose $\mathrm{E}^{0}$ is much higher than that of Fe (II), the dominated removal mechanisms were reduction and precipitation. The standard potential $\mathrm{E}^{0}$ of some environmentally relevant metals are given in Table 2 [98].

Table 2. Standard electrode potentials at $25{ }^{\circ} \mathrm{C}$ (Reproduced with permission from [98]. Copyright American Chemical Society, 2007).

\begin{tabular}{ccc}
\hline Metal & & $\mathbf{E}^{0}(\mathbf{V})$ \\
\hline Barium $(\mathrm{Ba})$ & $\mathrm{Ba}^{2+}+2 \mathrm{e}^{-} \leftrightarrow \mathrm{Ba}$ & -2.90 \\
Zinc (Zn) & $\mathrm{Zn}^{2+}+2 \mathrm{e}^{-} \leftrightarrow \mathrm{Zn}$ & -0.76 \\
Iron (Fe) & $\mathrm{Fe}^{2+}+2 \mathrm{e}^{-} \leftrightarrow \mathrm{Fe}$ & -0.41 \\
Cadmium $(\mathrm{Cd})$ & $\mathrm{Cd}^{2+}+2 \mathrm{e}^{-} \leftrightarrow \mathrm{Cd}$ & -0.40 \\
Nickel $(\mathrm{Ni})$ & $\mathrm{Ni}^{2+}+2 \mathrm{e}^{-} \leftrightarrow \mathrm{Ni}$ & -0.24 \\
Lead $(\mathrm{Pb})$ & $\mathrm{Pb}^{2+}+2 \mathrm{e}^{-} \leftrightarrow \mathrm{Pb}$ & -0.13 \\
Copper $(\mathrm{Cu})$ & $\mathrm{Cu}^{2+}+2 \mathrm{e}^{-} \leftrightarrow \mathrm{Cu}$ & 0.34 \\
Silver $(\mathrm{Ag})$ & $\mathrm{Ag}^{+}+\mathrm{e}^{-} \leftrightarrow \mathrm{Ag}$ & 0.80 \\
Mercury (Hg) & $\mathrm{Hg}^{2+}+2 \mathrm{e}^{-} \leftrightarrow \mathrm{Hg}$ & 0.86 \\
Chromium $(\mathrm{Cr})$ & $\mathrm{Cr}_{2} \mathrm{O}_{7}^{2-}+14 \mathrm{H}^{+}+6 \mathrm{e}^{-} \leftrightarrow 2 \mathrm{Cr}^{3+}+7 \mathrm{H}_{2} \mathrm{O}$ & 1.36 \\
\hline
\end{tabular}

Although using nZVI to remove heavy metal has many advantages, its shortcomings cannot be neglected. NZVI was reported to be oxidized with oxygen and water in an aqueous solution, slowing down or hindering the reduction process of the heavy metals [99]. nZVI was also reported to aggregate easily, resulting in the decrease of the reaction surface area and mobility [91]. Besides, the 
separation of nZVI from wastewater is difficult. In order to improve the performances of the nZVI, various kinds of modification strategies have been developed, such as surface chemical modification or doping nZVI with other metals (Pd, Cu, Ni, Pt, etc.) [100]. For example, Huang et al. synthesized a novel nZVI-modified material by combing nZVI with sodium dodecyl sulfate (SDS) which is one kind of anionic surfactant and possesses excellent abilities of migration and dispersion [101]. The maximum removal capacity of this novel nZVI material towards Cr (VI) was $253.68 \mathrm{mg} \cdot \mathrm{g}^{-1}$ in a batch adsorption experiment, indicating a promising adsorbent with an improved adsorption capacity and a decreased aggregation. The adsorption process was found to obey the Freundlich model and pseudo-second-order kinetic model well. Different factors such as $\mathrm{pH}$, contact time, dosage, and initial concentration were also investigated and a maximum removal efficiency of $98.919 \%$ could be achieved under optimum conditions. Su et al. investigated the removal of both Cd (II) and nitrate in water in a batch mode by using nZVI and Au-doped nZVI nanoparticles [102]. By using Au-doped $\mathrm{nZVI}$, the nitrite yield ration reduced from nitrate could be decreased significantly compared with the bare nZVI while the removal ration of Cd (II) remained at a high level. This result indicated that the Au-doped nZVI could be employed to treat wastewater containing both Cd (II) and nitrate. In addition to the two modification methods discussed above, nZVI-based nanocomposites are also receiving increasing attention. For example, Zarime et al. prepared a new nZVI-based nanocomposite by using low-cost bentonite to treat $\mathrm{Pb}$ (II), Cu (II), Cd (II), Co (II), Ni (II), and Zn (II) in water [103]. The introduction of bentonite to $\mathrm{nZVI}$ could decrease the aggregation of $\mathrm{nZVI}$ particles and provide the nZVI particles more adsorbing sites for heavy metals. Bentonite-nZVI composite exhibited a higher removal capacity towards these heavy metals compared with the mere bentonite. Not only employed in the laboratory level, there were also reports on the field tests of nZVI to remedy the groundwater in situ (Figure 4) [104].

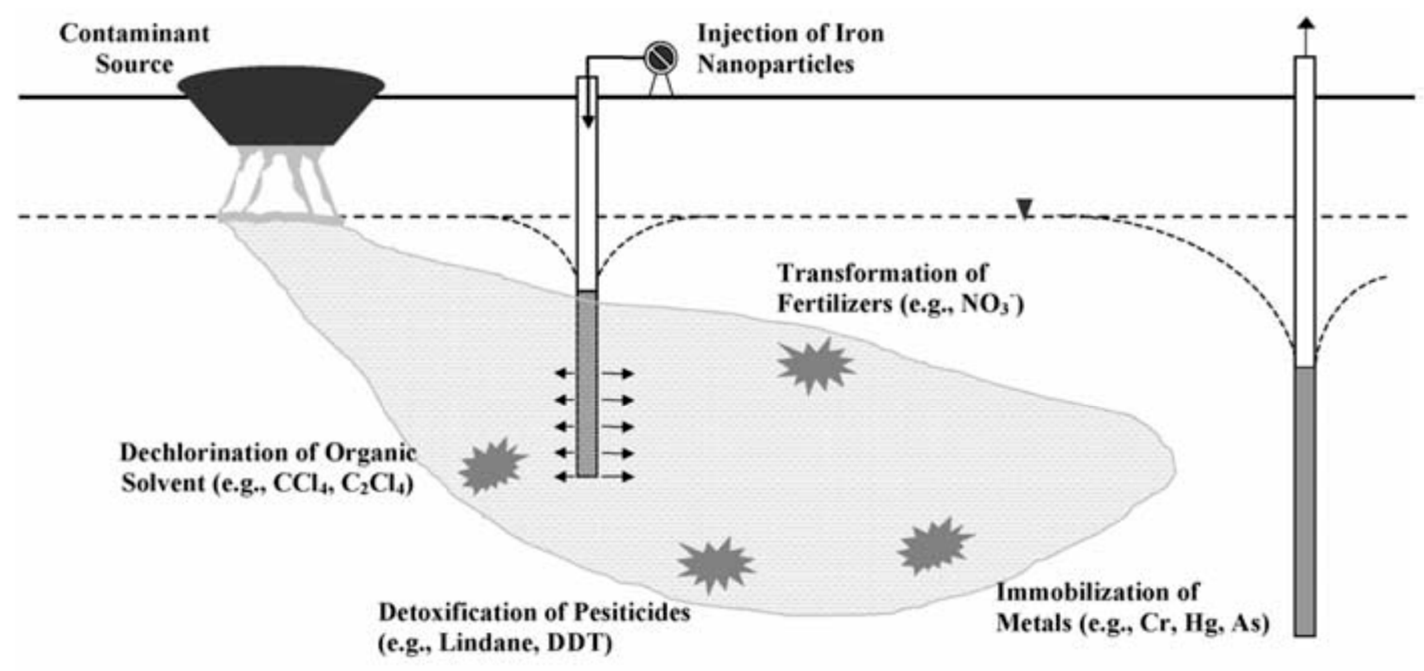

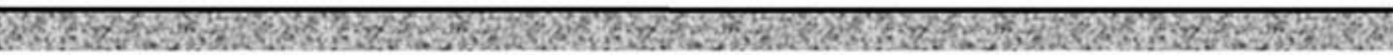

Figure 4. Nanoscale iron particles for in situ remediation. Reproduced with permission from [104]. Copyright Springer Nature, 2003.

\subsubsection{Ag Nanoparticles}

Unlike nZVI, reports on other metallic nanoparticles which could be used to remove heavy metals are not sufficient. There have been several reports about the interaction between Ag nanoparticles and $\mathrm{Hg}$ (II) $[105,106]$. Although the reactivity between $\mathrm{Hg}$ (II) and the bulk silver is not high, Ag nanoparticles can exhibit a higher reactivity because the reduction potential of Ag decreased with the diminution of the particle size [107]. E. Sumesh et al. synthesized a novel silver nanoparticle-based 
adsorbent by coordinating Ag with mercaptosuccinic acid (MSA) [108]. Two different materials were prepared and investigated by varying the ratio of Ag to MSA. The results demonstrated that 1:6 Ag@MSA had a higher removal capacity towards $\mathrm{Hg}$ (II) $\left(800 \mathrm{mg} \cdot \mathrm{g}^{-1}\right)$ compared with the common adsorbents. Furthermore, the authors stated that the cost for removing Hg (II) by employing Ag@MSA was competitive, indicating that Ag@MSA could be used as a promising alternative in the removal of $\mathrm{Hg}$ (II).

\subsubsection{Au Nanoparticles}

The affinity of $\mathrm{Hg}$ towards $\mathrm{Au}$ was generally recognized due to the fact that they could form $\mathrm{AuHg}, \mathrm{AuHg}_{3}$, and $\mathrm{Au}_{3} \mathrm{Hg}$ [109]. Lisha et al. investigated the removal effect towards $\mathrm{Hg}$ (II) by using gold nanoparticles which were supported on aluminum [110]. Both batch and column tests were carried out in this work. $\mathrm{NaBH}_{4}$ was used to reduce $\mathrm{Hg}$ (II) to $\mathrm{Hg}(0)$ and the results showed that the removal capacity of $\mathrm{Au}$ nanoparticles towards $\mathrm{Hg}(0)$ reached up to $4.065 \mathrm{~g} \cdot \mathrm{g}^{-1}$, which was much higher than the ordinary adsorbents. The expense of using this kind of Au nanoparticles to treat $\mathrm{Hg}$ (II) was estimated to be low and the used Au nanoparticles could be recovered efficiently, demonstrating that Au nanoparticles supported on aluminum could be applied to practical wastewater treatment. In another study, Jiménez et al. developed citrate-coated Au nanoparticles which could be used to treat $\mathrm{Hg}$ (II) in water (Figure 5) [111]. The citrate ions served as a weak reducing agent which could reduce $\mathrm{Hg}$ (II) to $\mathrm{Hg}(0)$, thus evading the employment of $\mathrm{NaBH}_{4}$. The removal experiments showed that the concentration of $\mathrm{Hg}$ (II) could be decreased from $65 \mathrm{ppb}$ to $1-5 \mathrm{ppb}$. The final product after the removal was $\mathrm{Au}_{3} \mathrm{Hg}$ alloy which could be treated at a high temperature or pressure later to recover $\mathrm{Au}[112]$.

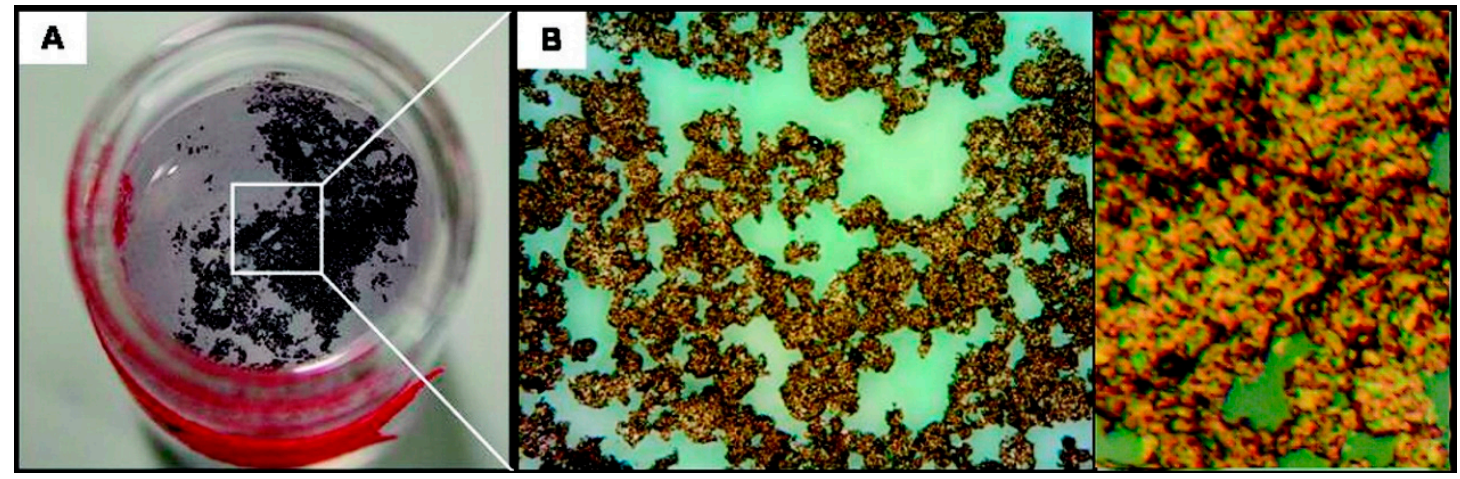

Figure 5. Removal of $\mathrm{Hg}$ from the Ebro River. (A) View of the precipitate resulting from the treatment of $6.5 \mathrm{ppm} \mathrm{Hg}$ (II) with Au NPs (1.7 nM Au NPs, $7.1 \mathrm{ppm} \mathrm{Au}$ ) in Ebro River water (41\% elimination). (B) Optical microscope image of the precipitate taken at $40 \times$ magnification and zoom. Reproduced with permission from [111]. Copyright American Chemical Society, 2012.

\subsection{Metal Oxide-Based Nanomaterials}

Nanosized metal oxides possess many exceptional properties, such as a high removal capacity and selectivity towards heavy metals. Thus, they have great potential as promising adsorbents for heavy metals. Generally speaking, metal oxides-based nanomaterials include nanosized iron oxides, manganese oxides, zinc oxides, titanium oxides, aluminum oxides, magnesium oxides, cerium oxides, and zirconium oxides, etc.

\subsubsection{Iron Oxides-Based Nanomaterials}

Iron oxide-based nanomaterials have received increasing attention in removing heavy metals from wastewater these years [113]. Iron is the fourth most abundant element in the Earth's crust [114]. The abundance of the iron element and the simplicity of synthesizing iron oxides contribute to the wide investigations on iron oxide-based nanomaterials. The most investigated iron oxides are goethite 
$\left(\alpha\right.$-FeOOH), hematite $\left(\alpha-\mathrm{Fe}_{2} \mathrm{O}_{3}\right)$, maghemite $\left(\gamma-\mathrm{Fe}_{2} \mathrm{O}_{3}\right)$, magnetite $\left(\mathrm{Fe}_{3} \mathrm{O}_{4}\right)$, and hydrous iron oxides (HFO) [26], which will be discussed below. For $\alpha-\mathrm{FeOOH}, \alpha-\mathrm{Fe}_{2} \mathrm{O}_{3}, \gamma-\mathrm{Fe}_{2} \mathrm{O}_{3}$, and HFO, the valences of iron are all trivalent, while for $\mathrm{Fe}_{3} \mathrm{O}_{4}$, iron exists both in bivalence and trivalence.

\section{Goethite $(\alpha-\mathrm{FeOOH})$}

Goethite $(\alpha-\mathrm{FeOOH})$, which already exists as a mineral in nature, is proven to be a competitive adsorbent towards heavy metals, thanks to its high adsorption efficiency, environmental safety and low cost [115]. Sun et al. prepared nanoscale $\alpha-\mathrm{FeOOH}$ by using different ferrous and ferric salts and employed it to remove uranium in water [116]. The results indicated that nanoscale $\alpha-\mathrm{FeOOH}$ had a much higher removal capacity towards uranium than that of non-nanoscale $\alpha-\mathrm{FeOOH}$, especially in the $\mathrm{pH}$ ranging from 5.5 to 7.5 . Chen et al. synthesized nanoscale goethite which could serve as both a photocatalyst and adsorbent towards heavy metals by using a coprecipitation method [117]. The batch adsorption experiment results showed that the nanoscale goethite exhibited some photocatalyst activity towards methylene blue solution under the irradiation of UV-light. Meanwhile, this newly-prepared nanoscale goethite also possessed a high adsorption capacity towards $\mathrm{Cu}$ (II) $\left(149.25 \mathrm{mg} \cdot \mathrm{g}^{-1}\right)$. The adsorption data fitted the pseudo-second-order equation and the Langmuir isotherm well. Thermodynamic data indicated that the adsorption process was spontaneous. Khezami et al. synthesized goethite nanocrystalline powders by using the high-energy ball milling method and employed them to treat Cd (II) in batch adsorption experiments [118]. The adsorption effect was greatly influenced by several adsorption factors and the maximum adsorption capacity of $167 \mathrm{mg} \cdot \mathrm{g}^{-1}$ could be obtained when $\mathrm{pH}=7$ and the temperature was $328 \mathrm{~K}\left(55^{\circ} \mathrm{C}\right)$. The adsorption data were in good agreement with both the Langmuir and Freundlich isotherms and the adsorption kinetics obeyed the pseudo-second-order model. The thermodynamics were also estimated and the results indicated that the adsorption process was spontaneous and endothermic. Goethite has also been reported to remove other heavy metals such as V (V), Mn (II), Ni (II), Co (II), Zn (II), Th (II) etc. [119-121].

\section{Hematite $\left(\alpha-\mathrm{Fe}_{2} \mathrm{O}_{3}\right)$}

Hematite $\left(\alpha-\mathrm{Fe}_{2} \mathrm{O}_{3}\right)$ is the most stable iron oxide and is highly resistant to corrosion [122]. Hematite nanoparticles have shown their application potentials in many fields, such as lithium ion batteries [123], environmental indicators [124], and catalysis [125]. What is more, hematite nanoparticles are also proven to be effective adsorbents towards heavy metals [126-128]. Adegoke et al. investigated the effect of morphologies of hematite nanoparticles on the removal of $\mathrm{Cr}$ (VI) [127]. Different morphologies of nano-hematite, including hexagonal, plate-like, nano-cubes, sub-rounded and spherical were synthesized and the removal capacities towards $\mathrm{Cr}$ (VI) were in the range of $6.33-200 \mathrm{mg} \cdot \mathrm{g}^{-1}$. The results indicated that morphologies play a significant role in the adsorption capacities of hematite. Shipley et al. studied the adsorption capacities of nano-hematite towards $\mathrm{Pb}$ (II), Cd (II), Cu (II), and Zn (II) [129]. Different operating factors, including the dosage of adsorbents, temperature, and multiple metal species were investigated. The affinity between the heavy metals and the adsorbent obeyed the following order: $\mathrm{Pb}$ (II) $>\mathrm{Zn}$ (II) $>\mathrm{Cd}$ (II) $>\mathrm{Cu}$ (II). The adsorption data fitted the pseudo-second-order rate model well, which indicates that the adsorption rate on the surface of the adsorbent is the rate-determining step. The thermodynamic data demonstrated that the adsorption for $\mathrm{Pb}$ (II), Cd (II), and Cu (II) was endothermic while that for $\mathrm{Zn}$ (II) was exothermic. The results showed that nano-hematite was an effective adsorbent which could remove multiple heavy metals from water simultaneously. Recently, superparamagnetic hematite nanoparticles were synthesized and used to treat the acid mine drainage (AMD) containing $\mathrm{Al}$ (III), $\mathrm{Mg}$ (II), $\mathrm{Mn}$ (II), $\mathrm{Zn}$ (II), Ni (II) etc. in a batch mode [130]. The results showed that nano-hematite could totally remove $\mathrm{Al}$ (III), $\mathrm{Mg}$ (II), and Mn (II), and could remove over $80 \%$ of Ni (II) and Zn (II). Given that nano-hematite possesses many merits such as non-toxicity, high stability, and an excellent metal adsorption capacity, it is a promising adsorbent to treat wastewater containing heavy metals. 
Maghemite $\left(\gamma-\mathrm{Fe}_{2} \mathrm{O}_{3}\right)$

Maghemite $\left(\gamma-\mathrm{Fe}_{2} \mathrm{O}_{3}\right)$ nanoparticles have been reported extensively to treat heavy metals in wastewater [131-133]. The advantages of maghemite nanoparticles for treating heavy metals lie in many aspects. Maghemite nanoparticles possess a large surface area which contributes to their high adsorption capacity. Besides, maghemite nanoparticles can be separated from wastewater easily after treatment by adding a magnetic field. Moreover, the synthesis of maghemite nanoparticles is simple and they are environment-friendly without producing secondary pollution [134]. Akhbarizadeh et al. synthesized maghemite nanoparticles with the average particle size of $14 \mathrm{~nm}$ by using a single-step method and employed them to treat wastewater containing $\mathrm{Cu}$ (II), $\mathrm{Ni}$ (II), $\mathrm{Mn}$ (II), Cd (II), and $\mathrm{Cr}$ (VI) by batch method [135]. The results showed that the affinity between maghemite nanoparticles and heavy metals were in the following order: $\mathrm{Cu}$ (II) $>\mathrm{Cr}$ (VI) $>\mathrm{Mn}$ (II) $>\mathrm{Ni}$ (II) $>\mathrm{Cd}$ (II). Rajput et al. synthesized superparamagnetic maghemite nanoparticles with a tunable morphology by employing a flame spray pyrolysis method [136]. The synthesized maghemite nanoparticles with a surface area of $79.35 \mathrm{~m}^{2} \cdot \mathrm{g}^{-1}$ were employed to remove $\mathrm{Pb}$ (II) and $\mathrm{Cu}$ (II) in wastewater. The batch adsorption results showed that the maximum Langmuir adsorption capacities were 68.9 and $34.0 \mathrm{mg} \cdot \mathrm{g}^{-1}$ for $\mathrm{Pb}$ (II) and $\mathrm{Cu}$ (II) respectively. Electrostatic interactions were mainly responsible for the metal ions adsorption. The surface of maghemite was covered with $\mathrm{FeOH}$ groups in water which could form positive $\mathrm{Fe}^{-}{ }^{+} \mathrm{OH}_{2}$ or negative $\mathrm{FeO}^{-}$groups with the change of $\mathrm{pH}$. More $\mathrm{Fe}$ (III) $\mathrm{O}^{-}$or $\mathrm{Fe}$ (III) $\mathrm{OH}$ sites formed with the increase of $\mathrm{pH}$, thus improving the adsorption capabilities for $\mathrm{Pb}$ (II) and $\mathrm{Cu}$ (II). While more $\mathrm{Fe}^{-}{ }^{+} \mathrm{OH}_{2}$ sites formed with the decrease of $\mathrm{pH}$, which repelled $\mathrm{Pb}$ (II) and $\mathrm{Cu}$ (II) on the surface and decreased the removal capacity.

In recent years, reports on polymer-modified maghemite nanomaterials, which combine the superiorities of both polymers and maghemite are gaining increasing attention. Madrakian et al. prepared a novel mercaptoethylamino monomer-modified maghemite nanomaterial (MAMNPs) via synthesis process shown in Scheme 1 [137]. The specific surface area of MAMNPs was $92.41 \mathrm{~m}^{2} \cdot \mathrm{g}^{-1}$ and the maximum removal capacities of $\mathrm{Ag}$ (I), $\mathrm{Hg}$ (II), $\mathrm{Pb}$ (II), and Cd (II) were 260.55, 237.60, 118.51, and $91.55 \mathrm{mg} \cdot \mathrm{g}^{-1}$ respectively by using the Sips isotherm. The batch adsorption data could be well represented by the pseudo-second-order kinetic model. Moreover, maghemite nanoparticles have also been reported to be modified by poly (1-vinylimidazole), polyrhodanine, polypyrrole, polyaniline etc. and these polymer-modified maghemite nanoparticles have exhibited good removal capabilities and selectivity towards heavy metal ions [138-140].

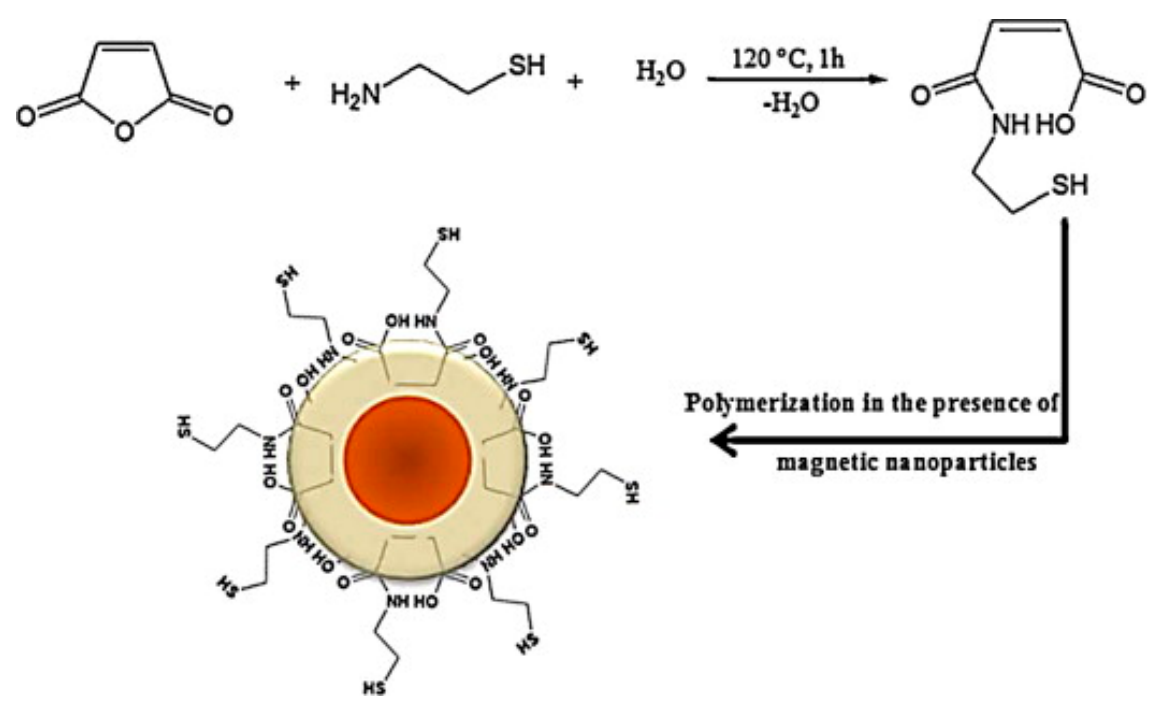

Scheme 1. Schematic representations of mercaptoethylamino monomer modified maghemite nanoparticles (MAMNPs) synthesis. Reproduced with permission from [137]. Copyright Elsevier, 2015. 
Magnetite $\left(\mathrm{Fe}_{3} \mathrm{O}_{4}\right)$

Magnetite $\left(\mathrm{Fe}_{3} \mathrm{O}_{4}\right)$-based nanomaterials are another kind of widely used nanometer adsorbent due to their low cost, simplicity of use, easy availability, and environmental friendliness [141]. Similar to maghemite, magnetite-based nanomaterials could be easily separated from the aqueous solution after treatment by adding a magnetic field (Figure 6). There have been numerous reports on their applications in heavy metals treatment [142-144]. Giraldo et al. synthesized magnetite nanoparticles by using a co-precipitation method and the obtained nanoparticles were used to treat $\mathrm{Pb}$ (II), $\mathrm{Cu}$ (II), $\mathrm{Zn}$ (II), and Mn (II) in a batch mode [145]. The results demonstrated that nanosized magnetite had the best adsorption effect towards $\mathrm{Pb}$ (II) $\left(0.180 \mathrm{mmol} \cdot \mathrm{g}^{-1}\right)$ while the least for $\mathrm{Mn}$ (II) $\left(0.140 \mathrm{mmol} \cdot \mathrm{g}^{-1}\right)$. This difference could result from the diverse electrostatic interactions between the heavy metal ions and the adsorbent sites. The Langmuir isotherm and pseudo-second-order model were found to be correlated with the adsorption data well. It was deduced that the size of hydrated ionic radii may affect the interactions with the negative charged adsorption site. When the hydrated ionic radii increased, the distance to the adsorbing surface would increase and the adsorption would be weaker. Given that $\mathrm{Pb}$ (II) had the lowest hydrated ionic radius and the maximum capability to compete with proton, it was reasonable that it had the highest adsorption capacity.
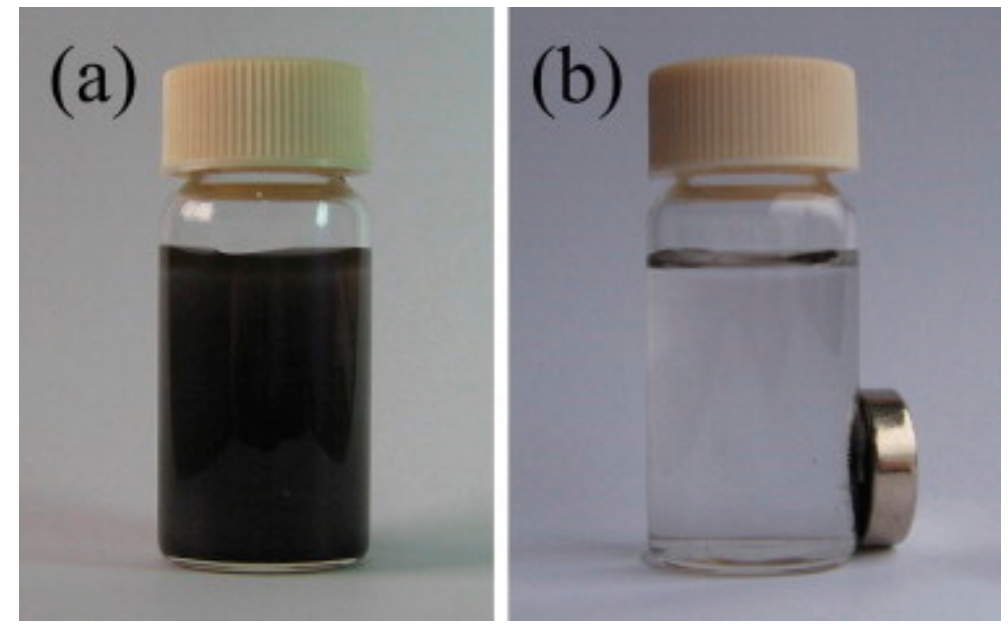

Figure 6. (a) Digital photograph of the $\mathrm{Pb}^{2+}$ solution with dispersed $\mathrm{Fe}_{3} \mathrm{O}_{4} @ \mathrm{SiO}_{2}$ composite microspheres and (b) digital photograph of the $\mathrm{Pb}^{2+}$ solution after magnetic separation using an external magnetic field. Reproduced with permission from [146]. Copyright Elsevier, 2010.

Nevertheless, bare magnetite nanoparticles are easily oxidized with oxygen due to the existence of Fe (II) in their structures, and they also tend to be corroded by acids or bases. Thus, magnetite particles are usually surface-modified by functional groups like $-\mathrm{NH}_{2}$ [147], - $\mathrm{COOH}$ [148], - $\mathrm{SH}$ [149] etc. or coated with a protective shell. Scheme 2 has given a schematic diagram of the core-shell structure based on PI-b-PEG diblock copolymer which encapsulated the single or multiple iron oxide nanoparticles [150]. In this study, $\mathrm{FeO}_{\mathrm{X}}-\mathrm{NPs}$ were coated with PI-DETA first and then encapsulated with different amounts of PI-b-PEG diblock copolymer. Baghani et al. synthesized amino functionalized $\mathrm{Fe}_{3} \mathrm{O}_{4}$ nanoparticles by using a simple one-pot method and investigated their adsorption effects towards $\mathrm{Cr}$ (VI) and Ni (II) [151]. The adsorption experiments were carried out in a batch mode and the maximum adsorption capacities for $\mathrm{Cr}$ (VI) and $\mathrm{Ni}$ (II) were $232.51 \mathrm{mg} \cdot \mathrm{g}^{-1}$ and $222.12 \mathrm{mg} \cdot \mathrm{g}^{-1}$ respectively by calculating from the Langmuir isotherm. The adsorption kinetics followed the pseudo-second-order model and the thermodynamic parameters demonstrated that the adsorption process was endothermic, spontaneous, and entropy favored in nature. The adsorbent after the treatment could be separated from the wastewater in $30 \mathrm{~s}$ by adding a magnetic field. As for the coating strategies to form core-shell structure, silica [152], sodium dodecyl sulphate [153], oleate [154], p-nitro aniline [155], polyethylene glycol [156], chitosan [157], tannic acid [158] etc. have been reported 
to be coated on the magnetite nanoparticles to treat heavy metals in wastewater. For example, Huang et al. synthesized a novel core-shell adsorbent by coating the organodisulfide polymer (PTMT) onto the amino-functionalized magnetite nanoparticles [159]. The newly-synthesized adsorbents showed high adsorption capacities toward high-concentration $\mathrm{Pb}$ (II), $\mathrm{Hg}$ (II) and $\mathrm{Cd}$ (II) in a batch adsorption experiment. When the initial concentrations of these three ions reached $600 \mathrm{mg} \cdot \mathrm{L}^{-1}$, the adsorption capacities of $\mathrm{Pb}$ (II), $\mathrm{Hg}$ (II), and Cd (II) were 533.13, 603.16, and $216.59 \mathrm{mg} \cdot \mathrm{g}^{-1}$, respectively. Moreover, the reusability of this adsorbent was also proven to be excellent. The re-adsorption capacities for $\mathrm{Hg}$ (II) and $\mathrm{Pb}$ (II) remained almost constant even after five cycles of regeneration while the removal capacity for $\mathrm{Cd}$ (II) decreased slightly. The modified magnetite nanomaterials with the core-shell structure have shown their great potential for removing heavy metals due to their excellent uptake capacities towards heavy metals and simplicity to be separated from wastewater by taking the advantages of both magnetite core and the organic or inorganic shells.
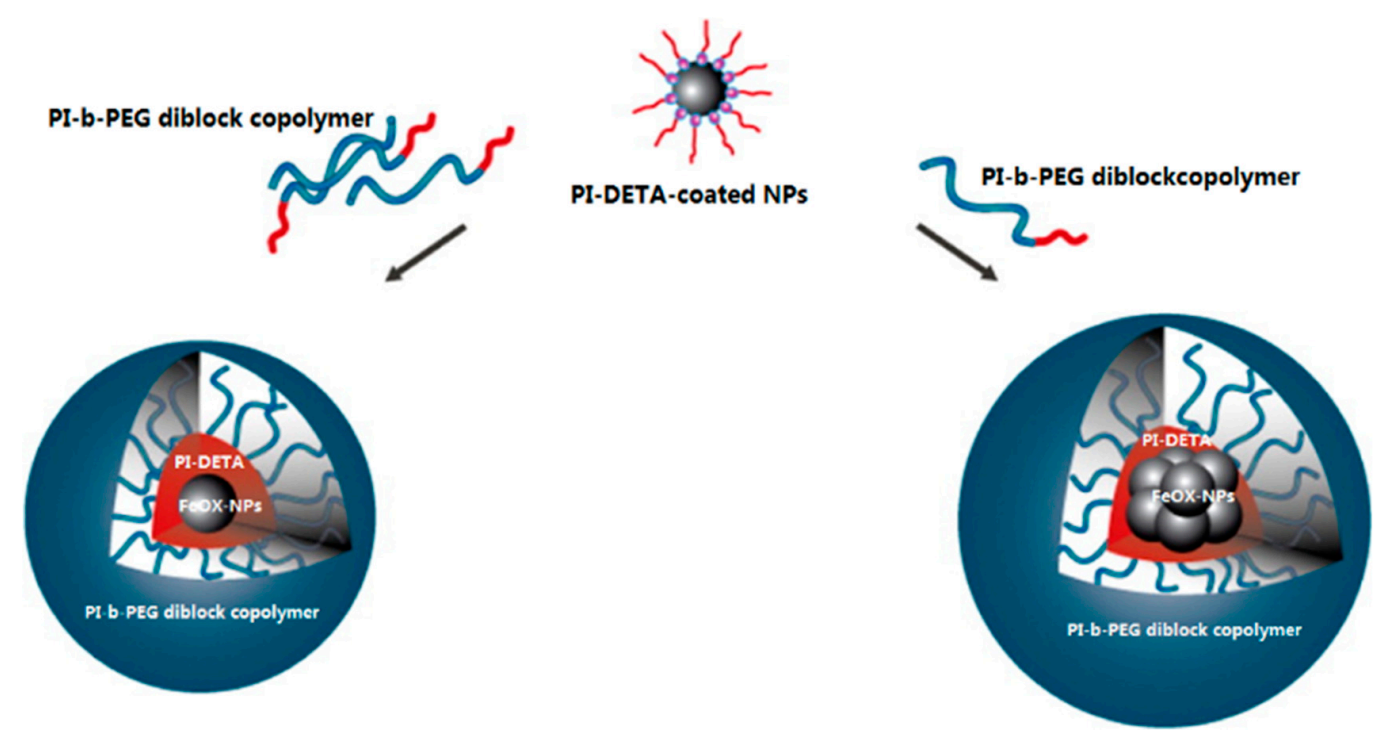

Scheme 2. Schematic Representation of the PI- $b$-PEG Diblock Copolymer Encapsulation of Single or Multiple NPs. Adapted with permission from [150]. Copyright American Chemical Society, 2014.

Hydrous Iron Oxides (HFO)

Hydrous iron oxides (HFO) nanoparticles have shown their great potential for removing heavy metals from wastewater due to their affinity towards heavy metals [160], large surface area [161] and their low cost. The removal mechanism consists of adsorption, ion-exchange and co-precipitation [162]. Though possessing many advantages for treating heavy metals, HFO nanoparticles cannot be used directly in stationary bed or flow-through systems due to their poor mechanical robustness, low hydraulic conductivity, and excessive pressure drop [163]. Thus, HFO are often combined with porous nanomaterials to form composites. For example, a hydrogel-supported HFO nanomaterial HFO-P(TAA/HEA) was prepared and its removal effect towards $\mathrm{Pb}$ (II), Cu (II), Cd (II) and Ni (II) from wastewater was investigated in batch mode [164]. The results showed that the removal order of this hybrid nanomaterial in quaternary system were in the following order: $\mathrm{Pb}$ (II) $>\mathrm{Cu}$ (II) $>\mathrm{Ni}$ (II) $>$ Cd (II). The adsorption capacities for these four ions in quaternary system were $0.432,0.231,0.1616$ and $0.0932 \mathrm{mmol} \cdot \mathrm{g}^{-1}$ respectively and they were all higher than that of mere HFO and mere hydrogel. It's worth noting that the coexistence of $\mathrm{Ca}$ (II) was proved to decrease the adsorption capacities of these four heavy metals which may be caused by competitive adsorption. Moreover, HFO nanoparticles were also reported to be an extremely effective adsorbent towards As with the uptake capacity of $92 \mathrm{mg} \cdot \mathrm{g}^{-1}$ calculated from Langmuir model [165]. In one study carried out by Huo et al. [166], carboxymethyl cellulose (CMC) modified HFO was synthesized to remove As (V) in the water. The results illustrated that the removal mechanism was mainly comprised of precipitation and surface complexation and the 
maximum adsorption capacity was $355 \mathrm{mg} \cdot \mathrm{g}^{-1}$, which was much higher than the capacities reported in previous literatures. Second-order model and dual-mode isotherm model were successfully used to correlate the sorption kinetics and isotherms of adsorption data in this study. Not limited to the laboratory use, this hybrid HFO-CMC nanomaterial was also employed to treat practical wastewater samples from Realgar mine tailings with an initial As (V) concentration of $38.2 \mathrm{mg} \cdot \mathrm{L}^{-1}$. The results indicated that HFO-CMC could remove $90.5 \%$ As $(\mathrm{V})$ and the As (V) concentration after the treatment was far below the standard of World Health Organization (WHO).

\subsubsection{Manganese Oxides-Based Nanomaterials}

Manganese oxides nanoparticles have also been reported to remove heavy metals from wastewater and nanosized manganese dioxide as well as hydrous manganese oxide (HMO) in which Mn is quadrivalve are mainly discussed here [167].

Nanocrystalline manganese oxide was found to have a high surface area which contributes to its good adsorption performance. Also, $\mathrm{M}-\mathrm{O}^{\delta+}$ and $\mathrm{M}-\mathrm{O}^{\delta-}$ units on the surface of manganese oxide would help the sorption of metal ions [168]. Wang et al. synthesized a novel dumbbell-like manganese dioxide/gelatin and investigated its adsorption performances towards $\mathrm{Pb}$ (II) and Cd (II) [169]. The batch adsorption study showed that the maximum adsorption capacities towards $\mathrm{Pb}$ (II) and Cd (II) were 318.7 and $105.1 \mathrm{mg} \cdot \mathrm{g}^{-1}$ respectively by calculating from the Langmuir model. The adsorption kinetic followed the pseudo-second-order model. What's more, this nanocomposite could be exploited to treat real water after being supported on an amino-functionalized PMMA plate. High removal capacity, simple operation and good stability implied that this nanocomposite could be applied to treating heavy metals in real water. Besides, nanoscale manganese dioxide could also be used in the adsorption and oxidation of $\mathrm{Tl}$ (I) in wastewater [170]. This batch adsorption process could be finished in $15 \mathrm{~min}$ and the maximum removal capacity was calculated to be $672 \mathrm{mg} \cdot \mathrm{g}^{-1}$ by using Langmuir model, indicating the potential of nanosized manganese oxides to be used in $\mathrm{Tl}$ treatment. In addition to these metals, manganese oxides-based nanomaterials have also been reported to treat other heavy metals like U, Cd(II), $\mathrm{Cu}(\mathrm{II}), \mathrm{Pb}(\mathrm{II}), \mathrm{Zn}(\mathrm{II}), \mathrm{Hg}(\mathrm{II})$ and so on [171-173].

Hydrous manganese oxide (HMO) is another kind of manganese oxides which have shown its advantages in heavy metals removal considering its high surface area, porous structures, and abundant sites for adsorption [160]. The coordination chemistry also plays a significant role in adsorption of HMO because hydroxyl groups on the HMO surface could coordinate with heavy metal ions [174]. The adsorption of heavy metal ions onto HMO was usually comprised of two steps: the quick adsorption of heavy metals onto the external surface and the slow intra-particle diffusion along the micro-pore walls of HMO. Recently, wan et al. prepared a HMO-BC nanocomposite by impregnating the HMO nanoparticles into the biochar (BC) [175]. HMO-BC nanocomposite exhibited an excellent removal effect towards $\mathrm{Pb}$ (II) and $\mathrm{Cd}$ (II) in a wide range of $\mathrm{pH}$. The combination of $\mathrm{HMO}$ and $\mathrm{BC}$ could avoid the drawbacks of employing BC individually such as the unsatisfactory adsorption capacity and poor selectivity. Fixed-bed column adsorption experiments demonstrated that the effective treatment capability of $\mathrm{HMO}-\mathrm{BC}$ for a simulated $\mathrm{Pb}$ (II) or $\mathrm{Cd}$ (II) containing wastewater was about 4-6 times higher than that of the $\mathrm{BC}$ host. Therefore, $\mathrm{HMO}-\mathrm{BC}$ is a promising alternative for removing heavy metals from the polluted water. 


\subsubsection{Zinc Oxides-Based Nanomaterials}

Zinc oxide nanoparticles have gained their popularity as adsorbents for heavy metals due to their high surface area, low cost and extraordinary removal capacity [176]. Nanosized zinc oxides have been reported to treat $\mathrm{Cr}$ (VI), $\mathrm{Cu}$ (II), Ni (II) and so on [176-178]. Sheela et al. [179] studied the removal performances of $\mathrm{ZnO}$ nanoparticles towards $\mathrm{Zn}$ (II), Cd (II) and $\mathrm{Hg}$ (II) by using batch method. The results demonstrated that the maximum adsorption capacities were $357,387,714 \mathrm{mg} \cdot \mathrm{g}^{-1}$ respectively by calculating from the Langmuir model, indicating a highly competitive adsorbent for these heavy metals. The effect of $\mathrm{pH}$ was investigated over the range of 4.0-8.0. The result indicated that $\mathrm{pH}$ had a significant influence on the adsorption behaviors which could be explained by the surface charge of the $\mathrm{ZnO}$ and degree of speciation of sorbents. Besides, a study carried out by Ghiloufi et al. compared the adsorption differences between $\mathrm{ZnO}$ nanoparticles and calcium doped $\mathrm{ZnO}$ nanoparticles towards Cr (VI), Cd (II)and Ni (II) [180]. The results indicated that the incorporation of Ca in ZnO nanoparticles could improve the uptake effect of these heavy metals. Somu et al. prepared zinc oxide nanoparticles by exploiting casein as the reducing and capping agent [181]. The casein-capped ZnO nanoparticles with an average size of $10 \mathrm{~nm}$ were employed to treat wastewater containing three metals and two dyes in batch mode. Adsorption data fitted the Langmuir model well and the adsorption capacities towards Cd (II), Pd (II) and Co (II) were 156.74, 194.93, $67.93 \mathrm{mg} \cdot \mathrm{g}^{-1}$ respectively and the uptake capacities towards methylene blue and congo red were 115.47 and $62.19 \mathrm{mg} \cdot \mathrm{g}^{-1}$. Besides, this casein-capped $\mathrm{ZnO}$ nanoparticles also exhibited excellent antimicrobial activity, indicating they are promising adsorbent towards the practical wastewater.

\subsubsection{Titanium Oxides-Based Nanomaterials}

Titanium oxides are extensively reported to photodegrade organic pollutants as effective photocatalytic [182]. There are also some reports on their applications on the heavy metal removal [183]. Gulaim et al. had prepared nano-titania with a mesoporous structure via a rapid surfactant-free approach and investigated its adsorption effect towards dichromate with $\mathrm{Cr}_{2} \mathrm{O}_{7}{ }^{2-}$ equilibrium concentrations varying from $20-300 \mathrm{mg} \cdot \mathrm{L}^{-1}$ [184]. The result indicated that the maximum adsorption capacity of the synthesized $\mathrm{TiO}_{2}$ towards $\mathrm{Cr}_{2} \mathrm{O}_{7}{ }^{2-}$ was $26.1 \mathrm{mg} \cdot \mathrm{g}^{-1}$, which was $12.6 \mathrm{mg} \cdot \mathrm{g}^{-1}$ for $\mathrm{Cr}$ (VI). This nano-titania showed a higher uptake capability towards $\mathrm{Cr}_{2} \mathrm{O}_{7}{ }^{2-}$ than that of the previously reported adsorbent. Youseff et al. synthesized $\mathrm{TiO}_{2}$ nanowire with an average diameter of 30-50 nm which was used to remove $\mathrm{Pb}$ (II), Cu (II), Fe (III), Cd (II), and Zn (II) from wastewater, and the results showed that $97.06 \%$ and $79.77 \%$ of $\mathrm{Pb}$ (II) and Fe (III) could be removed from the water respectively [185]. Besides, iron-doped $\mathrm{TiO}_{2}$ nanoparticles were also synthesized and they exhibited a higher removal capacity towards arsenic than that of pure $\mathrm{TiO}_{2}$ nanoparticles. This enhancement was attributed to the termination of grain growth and the response towards visible light [186]. Starch-coated $\mathrm{TiO}_{2}$ nanoparticles were prepared to remove Cd (II), $\mathrm{Co}$ (II), $\mathrm{Cu}$ (II), Ni (II), and $\mathrm{Pb}$ (II) in spiked tap-water and the recoveries of these metal ions were all over 90\% [187]. Recently, the microwave-enforced sorption (MES) approach was investigated to remove heavy metals from water by using microwave-synthesized $\mathrm{TiO}_{2}$-chitosan nanoparticles. MES technique was proven to be a green and rapid technique. The maximum adsorption capacity towards Cd (II) was $1800 \mu \mathrm{mol} \cdot \mathrm{g}^{-1}$. $86.80-88.01 \%$ and $72.56-70.67 \%$ of $\mathrm{Cu}$ (II) and Cd (II) could be removed from water by heating 60-70 s via MES technique [188]. However, the major drawbacks of titanium oxides nanoparticles lie in their complicated production process and separation difficulty [52]. It is usually difficult to separate $\mathrm{TiO}_{2}$ nanoparticles after the water treatment when $\mathrm{TiO}_{2}$ is implemented in a slurry suspension [189].

\subsubsection{Aluminum Oxides-Based Nanomaterials}

Aluminum oxides-based nanomaterials are another kind of widely used metal adsorbent towards heavy metals with the advantages of a low manufacturing cost and a high decontamination efficiency [190,191]. Aluminum oxide has several crystalline structures such as $\alpha, \gamma, \theta, \eta$ etc., among 
which $\gamma$-alumina is the most widely used [192]. $\gamma-\mathrm{Al}_{2} \mathrm{O}_{3}$ nanoparticles have a great potential as adsorbents attributing to their high specific surface area, excellent adsorption capacity, mechanical strength, and low-temperature modification [193]. Recently, Tabesh et al. synthesized $\gamma-\mathrm{Al}_{2} \mathrm{O}_{3}$ nanoparticles via a modified sol-gel method and investigated their adsorption effect towards $\mathrm{Pb}$ (II) and $\mathrm{Cd}$ (II) [194]. The average size of $\gamma-\mathrm{Al}_{2} \mathrm{O}_{3}$ nanoparticles was 6-13 $\mathrm{nm}$ and their maximum removal efficiency towards $\mathrm{Pb}$ (II) and $\mathrm{Cd}$ (II) achieved $97 \%$ and $87 \%$ respectively. The adsorption of $\mathrm{Pb}$ (II) and $\mathrm{Cd}$ (II) on $\gamma-\mathrm{Al}_{2} \mathrm{O}_{3}$ nanoparticles followed the Freundlich isotherm with an adsorption capacity of 47.08 and $17.22 \mathrm{mg} \cdot \mathrm{g}^{-1}$ respectively. Furthermore, a study which investigated the influence of phosphate $\left(\mathrm{PO}_{4}\right)$, citrate, and humic acid (HA) on the adsorption effect of $\mathrm{Al}_{2} \mathrm{O}_{3}$ nanoparticles towards $\mathrm{Zn}$ (II) and Cd (II) was also carried out and the result indicated that $\mathrm{PO}_{4}$ and $\mathrm{HA}$ could promote the adsorption of both $\mathrm{Zn}$ (II) and Cd (II), while citrate would decrease the adsorption of Zn (II) in a mono-metal system [195]. In addition to the above heavy metals, $\mathrm{Al}_{2} \mathrm{O}_{3}$ nanomaterials have also been reported to remove $\mathrm{Hg}$ (II), $\mathrm{As}$ (III), $\mathrm{Cu}$ (II), $\mathrm{Ni}$ (II), $\mathrm{Cr}$ (VI), etc. and have exhibited decent removal capabilities towards these elements [196-199].

\subsubsection{Magnesium Oxides-Based Nanomaterials}

Magnesium oxide nanoparticles have many advantages as adsorbents for heavy metals, including an extraordinary adsorption capacity, low cost, nontoxicity, abundance, and environmentally friendly character [200]. Moreover, $\mathrm{MgO}$ nanoparticles are also equipped with an excellent antibacterial ability towards Gram-positive and Gram-negative bacteria as well as bacterial spores [201]. Research has indicated that $\mathrm{Cd}$ (II), $\mathrm{Pb}$ (II), and Escherichia coli could be removed from water simultaneously via $\mathrm{MgO}$ nanoparticles synthesized by the sol-gel method [200]. Mahdavi et al. investigated the different adsorption effects of nanosized $\mathrm{TiO}_{2}, \mathrm{Al}_{2} \mathrm{O}_{3}$, and $\mathrm{MgO}$ towards $\mathrm{Cd}$ (II), $\mathrm{Cu}$ (II), $\mathrm{Ni}$ (II), and $\mathrm{Pb}$ (II) from aqueous solutions [202]. The maximum uptake capacities of $\mathrm{TiO}_{2}$ nanoparticles towards $\mathrm{Cd}$ (II), $\mathrm{Cu}$ (II), $\mathrm{Ni}$ (II), and $\mathrm{Pb}$ (II) were 120.1, 50.2, 39.3, and $21.7 \mathrm{mg} \cdot \mathrm{g}^{-1}$ respectively. The maximum uptake capacities of $\mathrm{Al}_{2} \mathrm{O}_{3}$ nanoparticles towards these four ions were $118.9,47.9,35.9$, and $41.2 \mathrm{mg} \cdot \mathrm{g}^{-1}$ while the adsorption capacities of $\mathrm{MgO}$ nanoparticles were $135,149.1,149.9$, and $148.6 \mathrm{mg} \cdot \mathrm{g}^{-1}$. The removal mechanism of $\mathrm{MgO}$ nanoparticles towards these four metals was attributed to adsorption and precipitation while the removal mechanisms of $\mathrm{TiO}_{2}$ and $\mathrm{Al}_{2} \mathrm{O}_{3}$ were mere adsorption. Tatenda $\mathrm{C}$. et al. synthesized $\mathrm{MgO}$ nanoparticles via a combustion method and investigated their removal capability towards $\mathrm{Cu}$ (II) [203]. The results indicated that $96 \%$ of $\mathrm{Cu}$ (II) could be removed from a $10 \mathrm{ppm}$ $\mathrm{CuCl}_{2}$ solution by using $0.2 \mathrm{~g} \mathrm{MgO}$ nanoparticles, while the commercial $\mathrm{MgO}$ only exhibited a removal efficiency of $15 \%$. Xiong et al. reported that the maximum adsorption capacities of $\mathrm{MgO}$ nanoparticles towards Cd (II) and $\mathrm{Pb}$ (II) were 2294 and $2614 \mathrm{mg} \cdot \mathrm{g}^{-1}$ respectively, by calculating from the Langmuir equation in a batch adsorption experiment [204]. The adsorption process was influenced simultaneously by external mass transfer and intraparticle diffusion. The high adsorption capacities were attributed to the generation of $\mathrm{OH}^{-}$dissociated from $\mathrm{Mg}(\mathrm{OH})_{2}$, which was hydrated from $\mathrm{MgO}$ and the synergistic effects of precipitation and adsorption helped to achieve this adsorption capacities. In another batch adsorption study carried out by Feng et al., mesoporous $\mathrm{MgO}$ nanosheets were prepared (Scheme 3.) and they exhibited extraordinary removal capacity towards $\mathrm{Ni}$ (II) with the value of $1684.25 \mathrm{mg} \cdot \mathrm{g}^{-1}$ calculated from the Langmuir model [205]. The pseudo-second-order model fitted the adsorption kinetic well. Distillation treating process could raise the $\mathrm{S}_{\mathrm{BET}}$ of $\mathrm{MgO}$ nanosheet up to $181.692 \mathrm{~m}^{2} \cdot \mathrm{g}^{-1}$. Therefore, $\mathrm{MgO}$ nanoparticles have exhibited a promising application potential for removing heavy metals from wastewater. 


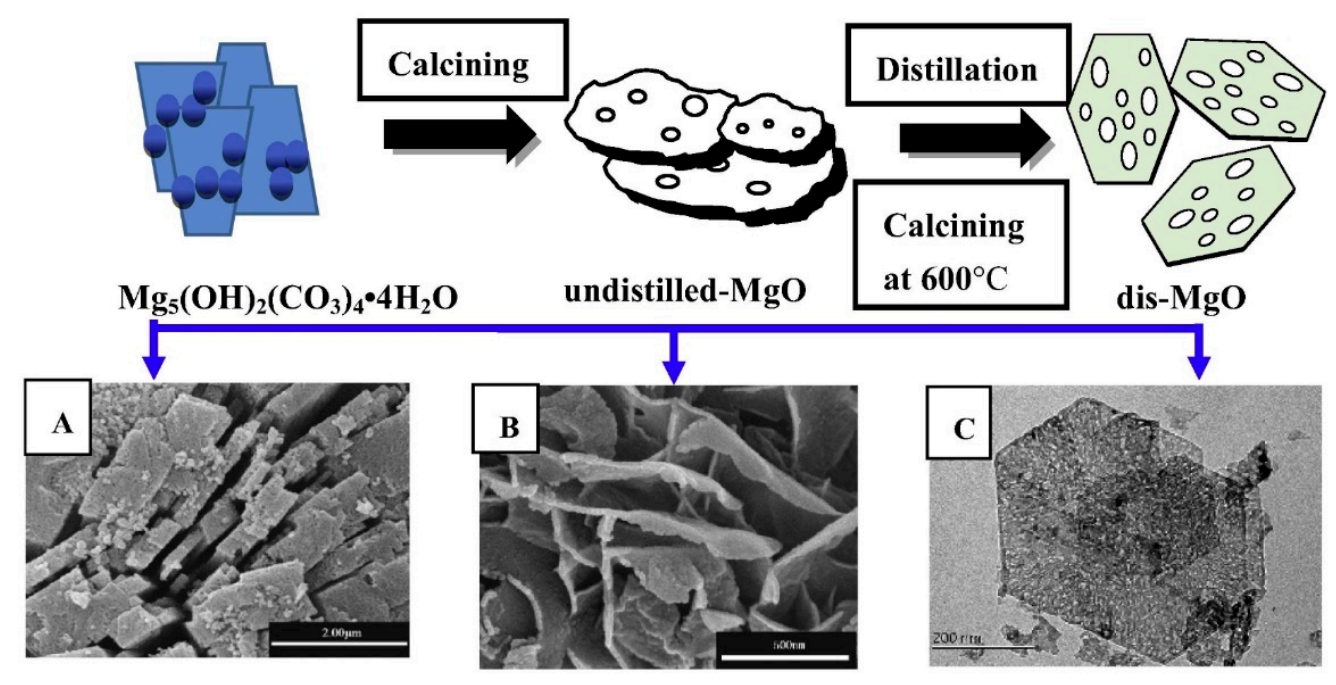

Scheme 3. Schematic illustration for the formation of mesoporous $\mathrm{MgO}$ nanosheets. Reproduced with permission from [205]. Copyright Elsevier, 2015.

\subsubsection{Cerium Oxides-Based Nanomaterials}

Nanosized cerium oxide $\left(\mathrm{CeO}_{2}\right)$, a non-harmful rare-earth oxide in which Ce is quadrivalve, have been applied in many areas such as photocatalysis and sensing [206], UV blocking [207], water treatment, etc. [208]. The crystalline size, bulk density, porosity, and surface area of $\mathrm{CeO}_{2}$ were reported to have great influence on their activity, stability, dispersion behavior, and selectivity, thus influencing the effect of heavy metals removal. Recillas et al. investigated the adsorption effect of $\mathrm{CeO}_{2}$ nanoparticles towards $\mathrm{Cr}$ (VI) from water [209]. The synthesized $\mathrm{CeO}_{2}$ nanoparticles had an average size of $12 \mathrm{~nm}$ and surface BET area of $65 \mathrm{~m}^{2} \cdot \mathrm{g}^{-1}$. The maximum adsorption capacity for $\mathrm{Cr}$ (VI) was $121.95 \mathrm{mg} \cdot \mathrm{g}^{-1}$ in this work with the initial $\mathrm{Cr}$ (VI) concentration of $80 \mathrm{mg} / \mathrm{L}$, indicating a good choice for removing low amounts of $\mathrm{Cr}(\mathrm{VI})$ from water. $\mathrm{CeO}_{2}$ nanoparticles with an average size of 3-5 $\mathrm{nm}$ and surface area of $257 \mathrm{~m}^{2} \cdot \mathrm{g}^{-1}$ were synthesized by Mishra et al. and they were used to remove As (III) and As (V) in water by the batch method [210]. The adsorption capacities towards these two ions were 71.9 and $36.8 \mathrm{mg} \cdot \mathrm{g}^{-1}$ respectively, as determined from the Langmuir isotherm and this adsorption process was almost complete after $10 \mathrm{~min}$. It is noteworthy that the coexistence of anions such as $\mathrm{H}_{2} \mathrm{PO}_{4}{ }^{-}, \mathrm{SO}_{4}{ }^{2-}$, and $\mathrm{HCO}_{3}{ }^{-}$would bring down the adsorption capacity. Moreover, $\mathrm{CeO}_{2}$ has also been reported to cooperate with other metal oxides to treat heavy metals [211,212]. Different morphologies of $\mathrm{CeO}_{2}$ nanopowder were prepared and the removal effect of samaria-doped ceria nanopowder (SDC) towards $\mathrm{Pb}$ (II), $\mathrm{Cu}$ (II), and $\mathrm{Zn}$ (II) was investigated [213]. The results showed that spherical SDC nanopowder (SDC-F) had a higher adsorption capacity than that of cluster plate-like SDC nanopowder (SDC-I).

\subsubsection{Zirconium Oxides-Based Nanomaterials}

Nanosized zirconium oxides are another kind of promising metallic oxides adsorbent which can be used to remove heavy metals in wastewater. Their advantages are that they have plenty of -OH on their surfaces and possess large surface areas. Moreover, nanosized zirconium oxides own great chemical stabilities and exhibit excellent adsorption affinities towards heavy metals like $\mathrm{Pb}$ (II), $\mathrm{Zn}$ (II) and Cd (II) [214]. Zirconium oxides nanomaterials discussed in this chapter are mainly comprised of nanosized zirconia and hydrous zirconia (HZO) based nanomaterials.

Gulaim et al. investigated the removal effects of a series of transition-metals which had mesoporous structures towards $\mathrm{Cr}$ (VI) in solutions, including $\mathrm{TiO}_{2}, \mathrm{ZrO}_{2}, \mathrm{HfO}_{2}, \mathrm{Nb}_{2} \mathrm{O}_{5}$, and $\mathrm{Ta}_{2} \mathrm{O}_{5}$ [215]. The synthesized metal oxides all exhibited large surface areas and were comprised of partially combined homogeneous nanoparticles with crystalline cores and amorphous shells. The 
adsorption capacity of $\mathrm{ZrO}_{2}$ for $\mathrm{Cr}(\mathrm{VI})$ was $73.0 \mathrm{mg} \cdot \mathrm{g}^{-1}$, indicating that mesoporous structure $\mathrm{ZrO}_{2}$ was an attractive adsorbent for $\mathrm{Cr}(\mathrm{VI})$. Yalçınkaya et al. synthesized a novel nanocomposite $\mathrm{ZrO}_{2} / \mathrm{B}_{2} \mathrm{O}_{3}$ and investigated its removal effects towards $\mathrm{Co}$ (II), $\mathrm{Cu}$ (II), and Cd (II) by column adsorption [216]. The adsorption capacities for $\mathrm{Co}$ (II), $\mathrm{Cu}$ (II), and $\mathrm{Cd}$ (II) were 32.2, 46.5, and $109.9 \mathrm{mg} \cdot \mathrm{g}^{-1}$ respectively by using Langmuir model and the reusability of this nanocomposite proved to be satisfactory. Hybrid nanocomposite $\mathrm{ZrO}_{2} / \mathrm{B}_{2} \mathrm{O}_{3}$ has provided a simple, economical, and selective method for the separation of $\mathrm{Co}$ (II), $\mathrm{Cu}$ (II), and Cd (II).

Nanosized hydrous zirconia (HZO) has also shown its great potential as adsorbent for heavy metals. Zhang et al. synthesized polystyrene-supported nanosized zirconium hydroxide HZO-PS and studied its removal effect towards Cd (II) [217]. The result indicated that Cd (II) could be removed by using this nanocomposite in a wide $\mathrm{pH}$ range varying from 2.5-7.0 with negligible $\mathrm{Zr}$ releases. Fixed-bed column adsorption experiment was also conducted and the results indicated that this nanocomposite has good applicability with the treated capacity of 750 bed volume per run. In another study carried out by Hua et al., HZO was combined with a commercial cation exchange resin D-001 to make a nanocomposite NZP [218]. The removal effects of NZP towards $\mathrm{Pb}$ (II) and $\mathrm{Cd}$ (II) were investigated by column adsorption method and the result demonstrated that the experimental maximum adsorption capacities for these two ions were 319.4 and $214.7 \mathrm{mg} \cdot \mathrm{g}^{-1}$ respectively. Pseudo-first-order model was found to fit the adsorption kinetics better. The cyclic column experiments showed that the synthesized NZP could be used to treat both synthetic and real acid mine wastewater repeatedly without any capacity loss when the $\mathrm{HNO}_{3}-\mathrm{Ca}\left(\mathrm{NO}_{3}\right)_{2}$ solution served as the regenerant.

\subsection{Nanocomposite Nanomaterials}

Despite the fact that each kind of nanomaterial discussed above has their own advantages, their respective drawbacks cannot be neglected. For example, it is difficult for CNTs to suspend uniformly in different solvents, while nZVI are prone to get oxidized [219]. Furthermore, nanoparticles often have the problem of aggregation, poor separation, and an excessive pressure drop when used in fixed-bed and flow-through systems [26,220]. A common strategy to solve these problems is to synthesize hybrid nanocomposites which take the advantages of different nanomaterials [109]. In this part, nanocomposites of inorganic and organic polymer supports, together with the magnetic nanocomposites are intensively discussed.

\subsubsection{Inorganic-Supported Nanocomposites}

Inorganic supports of nanocomposites which are used for heavy metals removal are mainly consisted of activated carbon (AC), CNTs, and some natural materials such as bentonite, montmorillonite, zeolite, and so on. AC is one of the most effective, economic and simplest adsorbent for pollutants in the aqueous solutions [221]. There have been some reports on the AC-supported nanocomposites which were used to remove heavy metals from water and these composites exhibited great potential for removing $\mathrm{Cr}$ (VI), $\mathrm{Pb}$ (II), Cd (II) etc. [222-225]. CNTs-supported nanocomposite is one kind of nanomaterial mainly supported on CNTs. Chitosan is one of the most widely used polymer to modify CNTs to prepare this kind of nanocomposites. Salam et al. prepared multi-walled CNTs/chitosan nanocomposite by sonicating the chitosan and CNTs suspension and then crosslinking them with glutaraldehyde (Figure 7) [226]. The composite was packed into a glass column to remove $\mathrm{Cu}$ (II), Zn (II), Cd (II), and Ni (II) from aqueous solution (Figure 8) and it exhibited high removal efficiency towards the targeted metal ions. Besides, polyethylenimine, 3-mercaptopropyltriethoxysilane, 8-hydroxyquinoline, cyclodextrin etc. have been reported to hybridize with CNTs to make nanocomposites [227-230]. Recently, Hayati et al. synthesized CNT coated poly-amidoamine dendrimer (PAMAM) nanocomposite (CNT/PAMAM) and investigated its adsorption efficiency towards As (III), Co (II), and Zn (II) in a fixed-bed system [231]. The maximum uptake capacities towards these three ions were 432,494 , and $470 \mathrm{mg} \cdot \mathrm{g}^{-1}$ respectively in column 
adsorption studies. Bentonite is one of the most potential candidates for treating high-concentration heavy metal pollution due to its excellent properties such as high specific area, cation exchange ability and adsorptive affinity [232]. NZVI, magnetite, hexadecyltrimethylammonium bromide (CTMAB), ethylene diamine tetraacetic acid (EDTA), 2-mercaptobenzothiazole (MBT), cellulose etc. were reported to be combined with bentonite and employed to remove heavy metals from aqueous solution $[30,103,233,234]$. Zeolite is another kind of promising host and stabilizer for nanoparticles due to its high surface area, excellent ion exchange ability, hydrophilic, environment-friendly characteristic and simply controllable chemical properties [235]. Hydroxyapatite/zeolite nanocomposite (HAp/NaP) was prepared to treat $\mathrm{Pb}$ (II) and $\mathrm{Cd}$ (II) in water by batch method and the maximum adsorption capacities of $\mathrm{Pb}$ (II) and Cd (II) were 55.55 and $40.16 \mathrm{mg} \cdot \mathrm{g}^{-1}$ respectively [236]. The adsorption kinetic could be correlated with the pseudo-second model perfectly. HAp/zeolite nanocomposite also exhibited antibacterial activity towards most common Gram-positive and Gram-negative bacteria, showing its application potential in water treatment. There are still many other inorganic supports of nanocomposite such as GO, sand, clay, etc., and they were found to be promising alternatives to remove heavy metals from wastewater $[24,237,238]$.

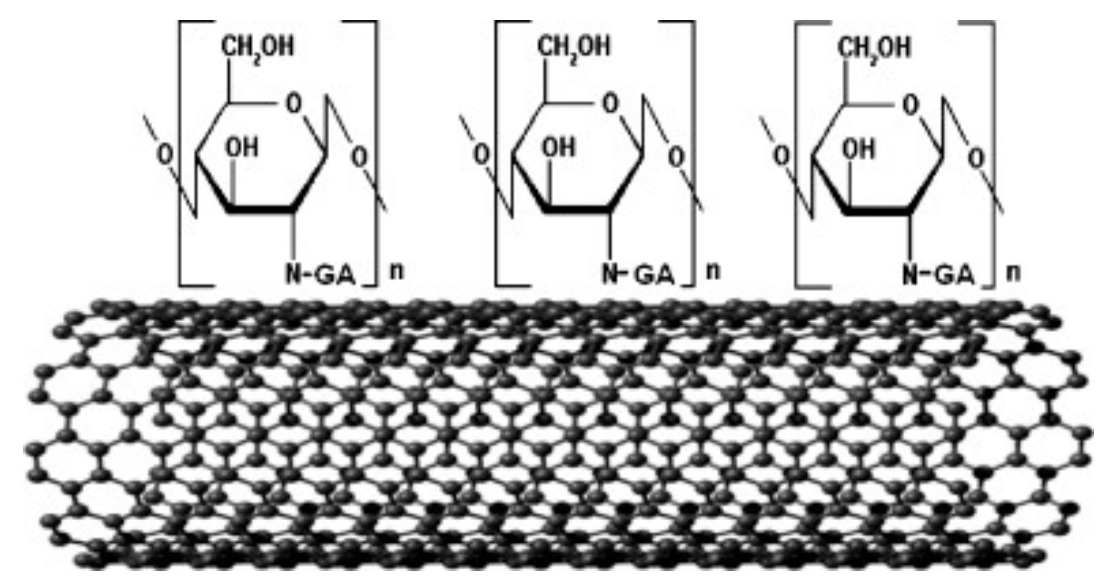

Figure 7. Physical structure of multi-walled CNTs/chitosan (MWCNTs/CS) nanocomposite. Reproduced with permission from [226]. Copyright Elsevier, 2011.

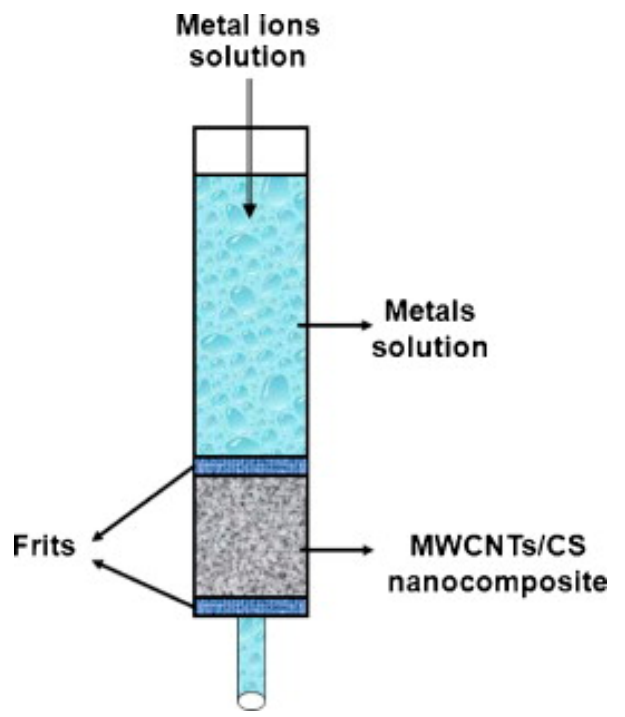

Figure 8. MWCNTs/CS nanocomposite packed inside a glass column. Reproduced with permission from [226]. Copyright Elsevier, 2011. 


\subsubsection{Organic Polymer-Supported Nanocomposites}

Polymeric hosts have many extraordinary properties, such as excellent mechanical strength, tunable functional groups, feasible regeneration, environmental soundness, and a degradable characteristic which make organic polymers a competitive option of hosts for nanocomposites [239]. Polymer-supported nanocomposites are comprised of two types, synthetic organic polymer-supported nanocomposites and biopolymer-supported nanocomposites [240]. The fabrication of polymer nanocomposites could be achieved by two ways, direct compounding and in situ synthesis, which are illustrated in Scheme 4 [109]. The synthetic organic polymer, such as polystyrene (PS), polyaniline, polyaniline (PAN), etc. [76,241,242], have been widely reported to fabricate nanocomposites which are exploited to treat heavy metals. For example, Afshar et al. fabricated polypyrrole-polyaniline $/ \mathrm{Fe}_{3} \mathrm{O}_{4}$ magnetic nanocomposite and investigated its removal capacity towards $\mathrm{Pb}$ (II) in an aqueous solution [243]. The synthesized nanocomposite could remove almost $100 \%$ of $\mathrm{Pb}$ (II) at $\mathrm{pH}=8-10$ when the concentration of $\mathrm{Pb}$ (II) was $20 \mathrm{mg} \cdot \mathrm{L}^{-1}$. Freundlich isotherm model and the pseudo-second order model fitted the adsorption data better.

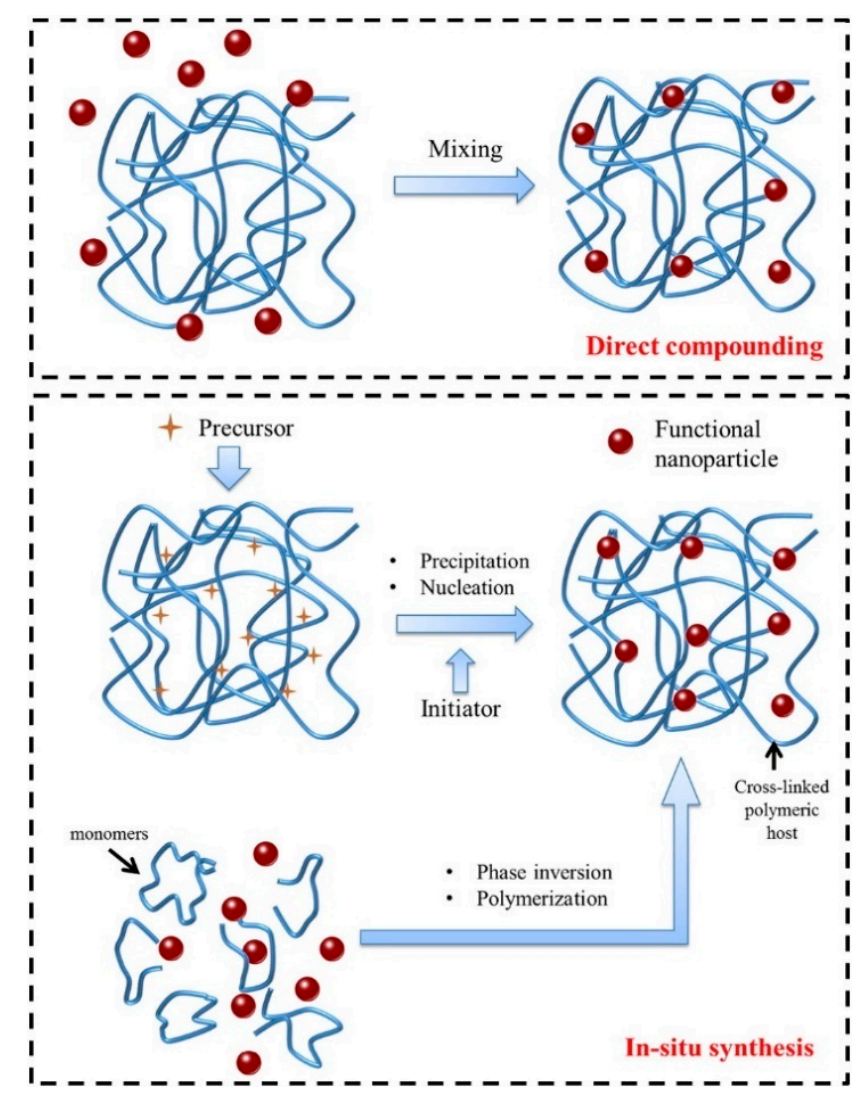

Scheme 4. Illustration of synthesis methods for polymeric nano-composites. Reproduced with permission from [109]. Copyright Elsevier, 2016.

Apart from the synthetic organic polymers, biopolymers like cellulose, chitosan, alginate, etc. are also extensively used as supports of nanocomposites. Cellulose, as one of the most common biopolymers, possesses hydroxyl groups on its glucose ring which provide abundant coordination sites for heavy metal ions. Thus, it is a promising starting material of adsorbents [244]. Suman et al. developed a nanocellulose (NC)-Ag nanoparticles (AgNPs) embedded pebbles-based composite material which was employed to remove dyes, heavy metals and microbes in water by column adsorption method [245]. The results indicated $99.48 \%$ of $\mathrm{Pb}$ (II) and $98.30 \%$ of $\mathrm{Cr}$ (III) were removed from water along with a $99 \%$ decontamination efficiency for microbial load. Chitosan is another eco-friendly and biodegradable material which has great potential for the adsorption of heavy metals 
due to the coexistence of $-\mathrm{NH}_{2}$ and $-\mathrm{OH}$ in its structure. Saad et al. synthesized $\mathrm{ZnO} /$ chitosan core-shell nanocomposite (ZOCS) which possessed the advantages of low cost and less biological toxicity and investigated its removal capabilities for $\mathrm{Pb}$ (II), Cd (II) and $\mathrm{Cu}$ (II) [246]. The batch adsorption results demonstrated that the maximum adsorption capacities for $\mathrm{Pb}$ (II), $\mathrm{Cd}$ (II), and $\mathrm{Cu}$ (II) were $476.1,135.1$, and $117.6 \mathrm{mg} \cdot \mathrm{g}^{-1}$ respectively according to the Langmuir isotherm model and this nanocomposite could be repeatedly used with an excellent adsorption capacity. Alginate, which is extracted from brown seaweed, is a non-toxic, biocompatible, and biodegradable biopolymer [247]. Gokila et al. fabricated the chitosan/alginate nanocomposite in order to remove $\mathrm{Cr}$ (VI) from wastewater [248]. The maximum adsorption capacity of $\mathrm{Cr}$ (VI) in the batch adsorption experiment was $108.8 \mathrm{mg} \cdot \mathrm{g}^{-1}$, and the adsorbent favored a multilayer adsorption. Lofrano et al. gave a detailed review on polymer functionalized nanocomposites (PFNCs) for the removal of metals from water, covering the preparation, characterization, toxicity, removal capabilities of PFNCs, and the interactions between the polymer hosts and nanoparticles [249]. Though the polymer-based nanocomposites have shown their great potential for heavy metals removal, their synthesis process, costs, recovery techniques, safety, etc. still need more investigation.

\subsubsection{Magnetic Nanocomposites}

Magnetic nanocomposites are one type of peculiar nanomaterial which have been receiving increasing attention due to their easy separation ability. Magnetic nanocomposites are mostly based on magnetic iron and iron oxides. The fabrication of these magnetic nanocomposites could be achieved mainly through three approaches: (1) Surface modification of magnetic iron/iron oxide nanoparticles by functional groups such as $-\mathrm{NH}_{2}$, $-\mathrm{SH}$ etc., which has been discussed in the previous chapter; (2) encapsulating the iron/iron oxide nanoparticles with other materials, such as humic acid, polyethylenimine, polyrhodanine, $\mathrm{MnO}_{2}$, polypyrrole, etc. to make a core-shell structure [139,172,250-252]; (3) coating the iron/iron oxide nanoparticles on some porous materials such as graphene oxide, CNTs, and so on $[253,254]$. Recently, Huang et al. synthesized a novel magnetic composite in which the nanosized $\mathrm{Fe}_{3} \mathrm{O}_{4} @ \mathrm{SiO}_{2}$ served as the core while the amino-decorated $\mathrm{Zr}$-based metal-organic frameworks (Zr-MOFs) acted as the shell [255]. The amino-decorated metal-organic frameworks composites exhibited an efficient removal capacity towards both $\mathrm{Pb}$ (II) and methylene blue. Ge et al. fabricated a Fe@MgO nanocomposite (Scheme 5) which combined the advantages of nZVI's strong magnetism and $\mathrm{MgO}^{\prime}$ s high adsorption capacity [256]. The maximum removal capacities of this nanocomposite towards $\mathrm{Pb}$ (II) and methyl orange were 1476.4 and $6947.9 \mathrm{mg} \cdot \mathrm{g}^{-1}$ respectively in batch adsorption experiments, indicating a great superiority for water treatment. The adsorption data of $\mathrm{Pb}$ (II) and methylene orange fitted the Langmuir model and the pseudo-second-order kinetic well, indicating that the adsorption onto the absorbent was a monolayer chemisorption.

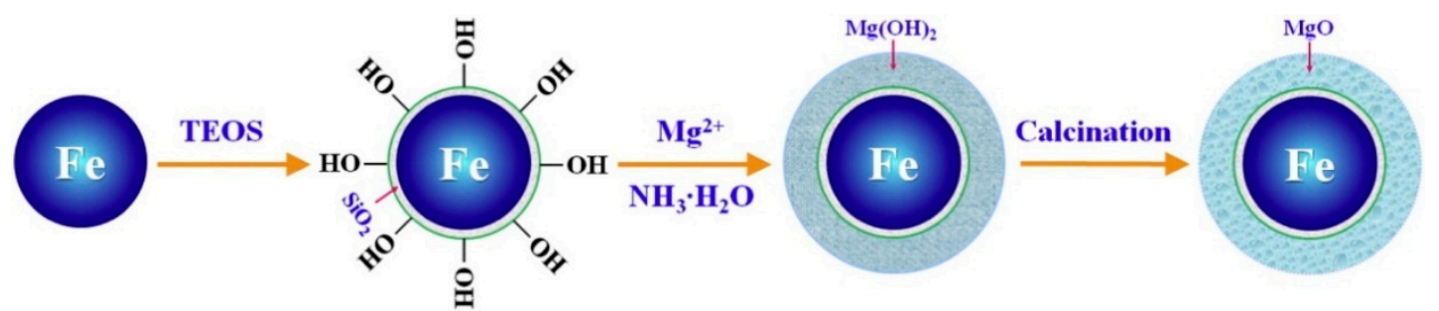

Scheme 5. Formation process of Fe@MgO nanocomposites. Reproduced with permission from [256]. Copyright Elsevier, 2018.

It is evident that magnetic nanocomposites possess great potential for the removal of heavy metals from water due to their easy separation property. However, the biocompatibilities of magnetic nanocomposites should be considered for a further adhibition. 


\section{Conclusions and Perspectives}

Nanomaterials have been extensively exploited to remove heavy metals in water owing to their exceptional properties. In this work, a series of nanomaterials, including carbon-based nanomaterials, zero-valent metal nanomaterials, metal oxide materials, and nanocomposites were discussed in detail. These materials are summarized in Table 3 at the end of this review. These nanomaterials exhibit great advantages as adsorbents towards heavy metals.

Nevertheless, there are still some bottlenecks that needed to be overcome to make better use of these nanomaterials in water treatment. First, most nanomaterials are unstable and tend to aggregate, thus reducing their removal capacity. Furthermore, it is usually difficult to separate the nanomaterials from the aqueous solution swiftly and efficiently due to their nanoscale size. The proposal of nanocomposites seems to be a promising approach to solving these problems. However, the synthesis process, long-term performance, and some other issues correlated with nanocomposites need further investigation. Second, the commercial nanomaterials used for heavy metals removal on an industry scale are rare and more efforts are needed to develop market-available nanomaterials. The synthesis, as well as operating costs of nanomaterials should be optimized for the sake of the economy and the production of these nanomaterials should meet the requirements of green chemistry. Last but not least, with the increasing use of nanomaterials in waste water treatment, their impacts and toxicities towards both the environment and human beings should be taken into consideration. Although there have been some literatures focused on the toxicity and biological behavior of nanoparticles towards human health $[257,258]$, the biocompatibility of nanomaterials with the environment also needs to be further investigated due to the insufficient criteria on the toxicity of nanomaterials nowadays. Regulations on the employment of nanomaterials are highly demanded in order to reduce the adverse effects of nanomaterials towards both environment and human beings.

In all, the treatment of heavy metal in wastewater is of great significance from the perspective of both the ecological environment and human health. The emergence of nanomaterials has provided us with a promising alternative to the traditional adsorbents for removing heavy metals. However, the removal capabilities of these nanomaterials are mostly investigated in stimulated water with relatively simple components. The reports of their use in practical wastewater are insufficient and are highly in need. Additionally, the interaction mechanisms between the hosts and guests of the nanocomposites demand a thorough understanding in order to guide the synthesis of nanocomposites. The risk and impacts of nanomaterials cannot be neglected when we develop them. There is still a long way to go to put nanomaterials into practical heavy metal water treatment, in particular when considering comprehensively their removal capability, reusability, separation, synthesis, and cost. 
Table 3. Nanomaterials discussed in this review.

\begin{tabular}{|c|c|c|c|c|}
\hline No. & Adsorbent & Adsorbate & Maximum Adsorption Capacity $\left(\mathrm{mg} \cdot \mathrm{g}^{-1}\right)$ & Refs. \\
\hline 1 & DESs-CNTs & $\mathrm{Hg}$ (II) & 186.97 & [61] \\
\hline 2 & amino-functionalized $\mathrm{Fe}_{3} \mathrm{O}_{4} / \mathrm{MWCNTs}$ & $\mathrm{Cu}$ (II) & 30.49 & [63] \\
\hline 3 & GO & $\mathrm{Zn}$ (II) & 246 & [69] \\
\hline 4 & few-layered GO nanosheets & $\mathrm{Cd}(\mathrm{II})$ and Co (II) & 106.3 and 68.2 & [70] \\
\hline 5 & functionalized GOCA beads & $\mathrm{Pb}$ (II), $\mathrm{Hg}$ (II) and Cd (II) & 602,374 and 181 & [71] \\
\hline 6 & GOx-microbots & $\mathrm{Pb}(\mathrm{II})$ & - & [72] \\
\hline 7 & Bifunctional silica nanospheres & $\mathrm{Cu}$ (II) and methylene blue. & 139.8 and 99.0 & [86] \\
\hline 8 & $\mathrm{NH}_{2}-\mathrm{SNHS}$ & $\mathrm{Pb}(\mathrm{II}), \mathrm{Cd}(\mathrm{II})$ and $\mathrm{Ni}(\mathrm{II})$ & $96.79,40.73$ and 31.29 & {$[87]$} \\
\hline 9 & Sil-Phy-NPANI & $\mathrm{Cu}(\mathrm{II}), \mathrm{Cd}(\mathrm{II}), \mathrm{Hg}$ (II) and $\mathrm{Pb}$ (II) & $108,90,120$ and 186 & [85] \\
\hline 10 & Sil-Phy-CrossNPANI & $\mathrm{Cu}(\mathrm{II}), \mathrm{Cd}(\mathrm{II}), \mathrm{Hg}$ (II) and $\mathrm{Pb}$ (II) & $105,118,271$ and 300 & {$[85]$} \\
\hline 11 & SDS-nZVI & $\mathrm{Cr}(\mathrm{VI})$ & 253.68 & [101] \\
\hline 12 & Au-doped nZVI & Cd (II) & 188 & [102] \\
\hline 13 & B-nZVI & $\mathrm{Pb}$ (II), Cu (II), Cd (II), Co (II), Ni (II) and Zn (II) & $50.25,70.20,14.25,12.90,16.50$ and 34.95 & [103] \\
\hline 14 & Ag@MSA & $\mathrm{Hg}(\mathrm{II})$ & 800 & [108] \\
\hline 15 & $\mathrm{Au}$ & $\mathrm{Hg}(0)$ & 4065 & [110] \\
\hline 16 & citrate-coated Au nanoparticles & $\mathrm{Hg}$ (II) & - & [111] \\
\hline 17 & $\alpha-\mathrm{FeOOH}$ & $\mathrm{Cu}$ (II) & 149.25 & [117] \\
\hline 18 & goethite nanocrystalline powders & Cd (II) & 167 & [118] \\
\hline 19 & nano-hematite & $\mathrm{Cr}(\mathrm{VI})$ & $6.33-200$ & [127] \\
\hline 20 & nano-hematite & $\mathrm{Pb}$ (II), Cd (II), Cu (II) and Zn (II) & - & [129] \\
\hline 21 & $\begin{array}{l}\text { superparamagnetic hematite } \\
\text { nanoparticles }\end{array}$ & $\mathrm{Al}$ (III), Mg (II), Mn (II), Zn (II), Ni (II) & - & {$[130]$} \\
\hline 22 & maghemite nanoparticles & $\mathrm{Cu}$ (II), Ni (II), Mn (II), Cd (II) and Cr (VI) & - & [135] \\
\hline 23 & maghemite nanoparticle & $\mathrm{Pb}$ (II) and $\mathrm{Cu}(\mathrm{II})$ & 68.9 and 34.0 & [136] \\
\hline 24 & MAMNPs & $\mathrm{Ag}(\mathrm{I}), \mathrm{Hg}$ (II), $\mathrm{Pb}$ (II) and Cd (II) & $260.55,237.60,118.51$ and 91.55 & [137] \\
\hline 25 & magnetite nanoparticles & $\mathrm{Pb}$ (II), Cu (II), Zn (II), Mn (II) & $37.3,10.8,10.5$ and 7.69 & [145] \\
\hline 26 & $\begin{array}{l}\text { amino functionalized } \mathrm{Fe}_{3} \mathrm{O}_{4} \\
\text { nanoparticles }\end{array}$ & $\mathrm{Cr}(\mathrm{VI})$ and $\mathrm{Ni}(\mathrm{II})$ & 232.51 and 222.12 & [151] \\
\hline 27 & $\mathrm{Fe}_{3} \mathrm{O}_{4} @ \mathrm{PTMT}$ & $\mathrm{Pb}$ (II), $\mathrm{Hg}$ (II) and Cd (II) & $533.13,603.16$ and 216.59 & [159] \\
\hline 28 & HFO-P(TAA/HEA) & $\mathrm{Pb}$ (II), $\mathrm{Cu}(\mathrm{II}), \mathrm{Cd}$ (II) and Ni (II) & $303.8,107.5,149.8$ and 85.87 & [164] \\
\hline 29 & HFO nanoparticles & As & 92 & [165] \\
\hline 30 & HFO-CMC & As $(\mathrm{V})$ & 355 & [166] \\
\hline 31 & manganese dioxide/gelatin & $\mathrm{Pb}$ (II) and $\mathrm{Cd}(\mathrm{II})$ & 318.7 and 105.1 & [169] \\
\hline 32 & nanoscale manganese dioxide & $\mathrm{Tl}(\mathrm{I})$ & 672 & [170] \\
\hline 33 & $\mathrm{ZnO}$ nanoparticles & $\mathrm{Zn}$ (II), Cd (II) and Hg (II) & 357,387 and 714 & [179] \\
\hline
\end{tabular}


Table 3. Cont.

\begin{tabular}{|c|c|c|c|c|}
\hline No. & Adsorbent & Adsorbate & Maximum Adsorption Capacity $\left(\mathrm{mg} \cdot \mathrm{g}^{-1}\right)$ & Refs. \\
\hline 34 & casein-capped $\mathrm{ZnO}$ nanoparticles & $\mathrm{Cd}$ (II), Pd (II) and Co (II) & $156.74,194.93$ and 67.93 & [181] \\
\hline 35 & nanosized $\mathrm{TiO}_{2}$ & $\mathrm{Cr}(\mathrm{VI})$ & 12.6 & [184] \\
\hline 36 & $\mathrm{TiO}_{2}$ nanowire & $\mathrm{Pb}$ (II), $\mathrm{Cu}(\mathrm{II}), \mathrm{Fe}(\mathrm{III}), \mathrm{Cd}(\mathrm{II})$ and $\mathrm{Zn}(\mathrm{II})$ & - & [185] \\
\hline 37 & Starch-coated $\mathrm{TiO}_{2}$ nanoparticles & $\mathrm{Cd}$ (II), $\mathrm{Co}$ (II), $\mathrm{Cu}$ (II), $\mathrm{Ni}$ (II) and $\mathrm{Pb}$ (II) & - & [187] \\
\hline 38 & $\mathrm{TiO}_{2}$-chitosan nanoparticles & $\mathrm{Cu}(\mathrm{II})$ and $\mathrm{Cd}(\mathrm{II})$ & - & [188] \\
\hline 39 & $\gamma-\mathrm{Al}_{2} \mathrm{O}_{3}$ nanoparticles & $\mathrm{Pb}(\mathrm{II})$ and $\mathrm{Cd}(\mathrm{II})$ & 47.08 and 17.22 & [194] \\
\hline 40 & $\mathrm{Al}_{2} \mathrm{O}_{3}$ nanoparticles & $\mathrm{Zn}$ (II) and Cd (II) & - & [195] \\
\hline 41 & $\mathrm{TiO}_{2}$ nanoparticles & $\mathrm{Cd}$ (II), $\mathrm{Cu}$ (II), $\mathrm{Ni}$ (II) and $\mathrm{Pb}$ (II) & $120.1,50.2,39.3$ and 21.7 & [202] \\
\hline 42 & $\mathrm{Al}_{2} \mathrm{O}_{3}$ nanoparticles & $\mathrm{Cd}$ (II), $\mathrm{Cu}$ (II), $\mathrm{Ni}$ (II) and $\mathrm{Pb}$ (II) & $118.9,47.9,35.9$ and 41.2 & [202] \\
\hline 43 & $\mathrm{MgO}$ nanoparticles & $\mathrm{Cd}$ (II), $\mathrm{Cu}$ (II), $\mathrm{Ni}$ (II) and $\mathrm{Pb}$ (II) & $135,149.1,149.9$ and 148.6 & [202] \\
\hline 44 & $\mathrm{MgO}$ nanoparticles & $\mathrm{Cu}(\mathrm{II})$ & - & [203] \\
\hline 45 & $\mathrm{MgO}$ nanoparticles & $\mathrm{Cd}(\mathrm{II})$ and $\mathrm{Pb}$ (II) & 2294 and 2614 & [204] \\
\hline 46 & mesoporous $\mathrm{MgO}$ nanosheets & $\mathrm{Ni}(\mathrm{II})$ & 1684.25 & [205] \\
\hline 47 & $\mathrm{CeO}_{2}$ nanoparticles & $\mathrm{Cr}(\mathrm{VI})$ & 121.95 & [209] \\
\hline 48 & $\mathrm{CeO}_{2}$ nanoparticles & As (III) and As (V) & 71.9 and 36.8 & [210] \\
\hline 49 & $\mathrm{CeO}_{2}$ nanopowder & $\mathrm{Pb}$ (II), $\mathrm{Cu}$ (II) and $\mathrm{Zn}$ (II) & $23,-,-$ & [213] \\
\hline 50 & mesoporous $\mathrm{ZrO}_{2}$ & $\mathrm{Cr}(\mathrm{VI})$ & 73.0 & {$[215]$} \\
\hline 51 & $\mathrm{ZrO}_{2} / \mathrm{B}_{2} \mathrm{O}_{3}$ nanocomposite & $\mathrm{Co}$ (II), $\mathrm{Cu}$ (II) and Cd (II) & $32.2,46.5$ and 109.9 & [216] \\
\hline 52 & HZO-PS & Cd (II) & - & {$[217]$} \\
\hline 53 & NZP & $\mathrm{Pb}$ (II) and $\mathrm{Cd}(\mathrm{II})$ & 319.4 and 214.7 & {$[218]$} \\
\hline 54 & CNTs/chitosan & $\mathrm{Cu}(\mathrm{II}), \mathrm{Zn}(\mathrm{II}), \mathrm{Cd}(\mathrm{II})$, and $\mathrm{Ni}$ (II) & - & [226] \\
\hline 55 & CNT/PAMAM & As (III), Co (II) and Zn (II) & 432,494 and 470 & [231] \\
\hline 56 & $\mathrm{HAp} / \mathrm{NaP}$ & $\mathrm{Pb}(\mathrm{II})$ and $\mathrm{Cd}(\mathrm{II})$ & 55.55 and 40.16 & [236] \\
\hline 57 & polypyrrole-polyaniline $/ \mathrm{Fe}_{3} \mathrm{O}_{4}$ & $\mathrm{~Pb}(\mathrm{II})$ & 243.9 & [243] \\
\hline 58 & NC-AgNPs & $\mathrm{Pb}(\mathrm{II})$ and $\mathrm{Cr}(\mathrm{III})$ & 9.42 and 8.93 & [245] \\
\hline 59 & ZOCS & $\mathrm{Pb}$ (II), $\mathrm{Cd}$ (II) and $\mathrm{Cu}$ (II) & $476.1,135.1$ and 117.6 & [246] \\
\hline 60 & chitosan/alginate nanocomposite & $\mathrm{Cr}(\mathrm{VI})$ & 108.8 & [248] \\
\hline 61 & $\mathrm{Fe} 3 \mathrm{O} 4 @ \mathrm{SiO}_{2} / \mathrm{Zr}-\mathrm{MOFs}$ & $\mathrm{Pb}$ (II) & 102 & [255] \\
\hline 62 & $\mathrm{Fe} @ \mathrm{MgO}$ & $\mathrm{Pb}$ (II) & 1476.4 & [256] \\
\hline
\end{tabular}


Funding: This research was funded by the National Key Research and Development Program (No. 2016YFB0600504)

Conflicts of Interest: The authors declare no conflict of interest.

\section{References}

1. Cheraghi, M.; Lorestani, B.; Yousefi, N. Effect of waste water on heavy metal accumulation in Hamedan Province vegetables. Int. J. Bot. 2009, 5, 190-193. [CrossRef]

2. Reglero, M.M.; Taggart, M.A.; Lidia, M.G.; Rafael, M. Heavy metal exposure in large game from a lead mining area: Effects on oxidative stress and fatty acid composition in liver. Environ. Pollut. 2009, 157, 1388-1395. [CrossRef] [PubMed]

3. Gybina, A.A.; Prohaska, J.R. Copper deficiency results in AMP-activated protein kinase activation and acetylCoA carboxylase phosphorylation in rat cerebellum. Brain Res. 2008, 1204, 69-76. [CrossRef] [PubMed]

4. Kampa, M.; Castanas, E. Human health effects of air pollution. Environ. Pollut. 2008, 151, 362-367. [CrossRef] [PubMed]

5. Afroze, S.; Sen, T.K. A Review on Heavy Metal Ions and Dye Adsorption from Water by Agricultural Solid Waste Adsorbents. Water Air Soil Pollut. 2018, 229, 225. [CrossRef]

6. Cocârţă, D.; Neamţu, S.; Deac, A.R. Carcinogenic risk evaluation for human health risk assessment from soils contaminated with heavy metals. Int. J. Environ. Sci. Technol. 2016, 13, 2025-2036. [CrossRef]

7. González-Muñoz, M.J.; Rodríguez, M.A.; Luque, S.; Álvarez, J.R. Recovery of heavy metals from metal industry waste waters by chemical precipitation and nanofiltration. Desalination 2006, 200, 742-744. [CrossRef]

8. Verbych, S.; Hilal, N.; Sorokin, G.; Leaper, M. Ion Exchange Extraction of Heavy Metal Ions from Wastewater. Separat. Sci. Technol. 2004, 39, 2031-2040. [CrossRef]

9. Namasivayam, C.; Sangeetha, D. Recycling of agricultural solid waste, coir pith: Removal anions, heavy metals, organics and dyes from water by adsorption onto $\mathrm{ZnCl}_{2}$ activated coir pith carbon. J. Hazard. Mater. 2006, 135, 449-452. [CrossRef]

10. Sudilovskiy, P.S.; Kagramanov, G.G.; Trushin, A.M.; Kolesnikov, V.A. Use of membranes for heavy metal cationic wastewater treatment: Flotation and membrane filtration. Clean Technol. Environ. Policy 2007, 9 , 189-198. [CrossRef]

11. Tran, T.K.; Leu, H.J.; Chiu, K.F.; Lin, C.Y. Electrochemical Treatment of Heavy Metal-containing Wastewater with the Removal of COD and Heavy Metal Ions: Electrochemical treatment of heavy metal containing wastewater. J. Chin. Chem. Soc. 2017, 64, 493-502. [CrossRef]

12. Mavrov, V.; Erwe, T.; Blöcher, C.; Chmiel, H. Study of new integrated processes combining adsorption, membrane separation and flotation for heavy metal removal from wastewater **. Desalination 2003, 157, 97-104. [CrossRef]

13. Blöcher, C.; Dorda, J.; Mavrov, V.; Chmiel, H.; Lazaridis, N.K.; Matis, K.A. Hybrid flotation-Membrane filtration process for the removal of heavy metal ions from wastewater. Water Res. 2003, 37, 4018-4026. [CrossRef]

14. Khan, N.A.; Hasan, Z.; Jhung, S.H. Adsorptive removal of hazardous materials using metal-organic frameworks (MOFs): A review. J. Hazard. Mater. 2013, 244-245, 444-456. [CrossRef]

15. Ricco, R.; Konstas, K.; Styles, M.J.; Richardson, J.J.; Babarao, R.; Suzuki, K.; Scopece, P.; Falcaro, P. Lead(II) uptake by aluminium based magnetic framework composites (MFCs) in water. J. Mater. Chem. A 2015, 3, 19822-19831. [CrossRef]

16. Fatikow, S.; Eichhorn, V.; Bartenwerfer, M. Nanomaterials Enter the Silicon-Based CMOS Era: Nanorobotic Technologies for Nanoelectronic Devices. IEEE Nanotechnol. Mag. 2012, 6, 14-18. [CrossRef]

17. Kumar, S.; Ahlawat, W.; Kumar, R.; Dilbaghi, N. Graphene, carbon nanotubes, zinc oxide and gold as elite nanomaterials for fabrication of biosensors for healthcare. Biosens. Bioelectron. 2015, 70, 498-503. [CrossRef]

18. Pumera, M. Graphene-based nanomaterials for energy storage. Energy Environ. Sci. 2011, 4, 668-674. [CrossRef]

19. Kharisov, B.I.; Kharissova, O.V.; Dias, H.V.R. Nanomaterials for Environmental Protection; John Wiley \& Sons, Inc.: Hoboken, NJ, USA, 2014. 
20. Buzea, C.; Pacheco, I. Nanomaterial and Nanoparticle: Origin and Activity; Springer International Publishing: Cham, Switzerland, 2017.

21. Shi, Y.H.; Wang, C.Z.; Zi-Rong, X.U. The application and prospect of nanotechnology in animal husbandry. J. Northwest Sci-Tech Univ. Agric. For. (Nat. Sci. Ed.) 2006, 34, 49-52.

22. Vunain, E.; Mishra, A.K.; Mamba, B.B. Dendrimers, mesoporous silicas and chitosan-based nanosorbents for the removal of heavy-metal ions: A review. Int. J. Biol. Macromol. 2016, 86, 570-586. [CrossRef]

23. Lim, J.Y.; Mubarak, N.M.; Abdullah, E.C.; Nizamuddin, S.; Khalid, M.; Inamuddin. Recent trends in the synthesis of graphene and graphene oxide based nanomaterials for removal of heavy metals-A review. J. Ind. Eng. Chem. 2018, 66, 29-44. [CrossRef]

24. Nujić, M.; Habuda-Stanić, M. Toxic Metal Ions in Drinking Water and Effective Removal Using Graphene Oxide Nanocomposite; Springer International Publishing: Cham, Switzerland, 2019; pp. 373-395.

25. Ihsanullah; Abbas, A.; Al-Amer, A.M.; Laoui, T.; Al-Marri, M.J.; Nasser, M.S.; Khraisheh, M.; Atieh, M.A. Heavy metal removal from aqueous solution by advanced carbon nanotubes: Critical review of adsorption applications. Separat. Purif. Technol. 2016, 157, 141-161. [CrossRef]

26. Ming, H.; Zhang, S.; Pan, B.; Zhang, W.; Lu, L.; Zhang, Q. Heavy metal removal from water/wastewater by nanosized metal oxides: A review. J. Hazard. Mater. 2012, 211-212, 317-331.

27. Wang, X. Nanomaterials as Sorbents to Remove Heavy Metal Ions in Wastewater Treatment. J. Environ. Anal. Toxicol. 2012, 02, 154. [CrossRef]

28. Lee, Z.L.; Zaini, M.A.A.; Tang, S.H. Porous Nanomaterials for Heavy Metal Removal; Springer International Publishing: Cham, Switzerland, 2019.

29. Theodore, L.; Ricci, F. Mass Transfer Operations for the Practicing Engineer; John Wiley \& Sons, Inc.: Hoboken, NJ, USA, 2011.

30. Putro, J.N.; Santoso, S.P.; Ismadji, S.; Ju, Y.H. Investigation of heavy metal adsorption in binary system by nanocrystalline cellulose-Bentonite nanocomposite: Improvement on extended Langmuir isotherm model. Microporous Mesoporous Mater. 2017, 246, 166-177. [CrossRef]

31. Baseri, H.; Tizro, S. Treatment of nickel ions from contaminated water by magnetite based nanocomposite adsorbents: Effects of thermodynamic and kinetic parameters and modeling with Langmuir and Freundlich isotherms. Process Saf. Environ. Protect. 2017, 109, 465-477. [CrossRef]

32. Danish, M.; Hashim, R.; Mohamad Ibrahim, M.N.; Rafatullah, M.; Sulaiman, O.; Ahmad, T.; Shamsuzzoha, M.; Ahmad, A. Sorption of Copper(II) and Nickel(II) Ions from Aqueous Solutions Using Calcium Oxide Activated Date (Phoenix dactylifera) Stone Carbon: Equilibrium, Kinetic, and Thermodynamic Studies. J. Chem. Eng. Data 2011, 56, 3607-3619. [CrossRef]

33. Repo, E.; Warchol, J.K.; Kurniawan, T.A.; Sillanpää, M.E.T. Adsorption of Co(II) and Ni(II) by EDTA- and/or DTPA-modified chitosan: Kinetic and equilibrium modeling. Chem. Eng. J. 2010, 161, 73-82. [CrossRef]

34. Wei, S.; Chen, S.; Shi, S.; Li, X.; Zhang, X.; Hu, W.; Wang, H. Adsorption of Cu(II) and Pb(II) onto diethylenetriamine-bacterial cellulose. Carbohydr. Polym. 2009, 75, 110-114.

35. Sha, L.; Guo, X.; Feng, N.; Tian, Q. Adsorption of $\mathrm{Cu}$ and $\mathrm{Cd}$ from aqueous solution by mercapto-acetic acid modified orange peel. Colloids Surf. B Biointerfaces 2009, 73, 10-14. [CrossRef]

36. Ho, Y.-S.; Chiu, W.-T.; Wang, C.-C. Regression analysis for the sorption isotherms of basic dyes on sugarcane dust. Bioresour. Technol. 2005, 96, 1285-1291. [CrossRef]

37. Ramanaiah, S.V.; Mohan, S.V.; Sarma, P.N. Adsorptive removal of fluoride from aqueous phase using waste fungus (Pleurotus ostreatus 1804) biosorbent: Kinetics evaluation. Ecol. Eng. 2007, 31, 47-56. [CrossRef]

38. Freundlich, H. Over the adsorption in the solution. J. Phys. Chem. 1906, 57, 385-470.

39. Sips, R. On the Structure of a Catalyst Surface. J. Chem. Phys. 2004, 16, 1024-1026. [CrossRef]

40. Al-Asheh, S.; Banat, F.; Al-Omari, R.; Duvnjak, Z. Predictions of binary sorption isotherms for the sorption of heavy metals by pine bark using single isotherm data. Chemosphere 2000, 41, 659-665. [CrossRef]

41. Ho, Y.S.; Porter, J.F.; Mckay, G. Equilibrium Isotherm Studies for the Sorption of Divalent Metal Ions onto Peat: Copper, Nickel and Lead Single Component Systems. Water Air Soil Pollut. 2002, 141, 1-33. [CrossRef]

42. Repo, E.; Warchoł, J.K.; Bhatnagar, A.; Sillanpää, M. Heavy metals adsorption by novel EDTA-modified chitosan-silica hybrid materials. J. Colloid Interface Sci. 2011, 358, 261-267. [CrossRef]

43. Matouq, M.; Jildeh, N.; Qtaishat, M.; Hindiyeh, M.; Syouf, M.Q.A. The adsorption kinetics and modeling for heavy metals removal from wastewater by Moringa pods. J. Environ. Chem. Eng. 2015, 3, 775-784. [CrossRef] 
44. ÇAvuş, S.; GuRdag, G.L. Noncompetitive Removal of Heavy Metal Ions from Aqueous Solutions by Poly[2-(acrylamido)-2-methyl-1-propanesulfonic acid-co-itaconic acid] Hydrogel. Ind. Eng. Chem. Res. 2016, 48, 2652-2658. [CrossRef]

45. Farhan, A.M.; Salem, N.M.; Al-Dujaili, A.H.; Awwad, A.M. Biosorption Studies of Cr(VI) Ions from Electroplating Wastewater by Walnut Shell Powder. Am. J. Environ. Eng. 2012, 2, 188-195. [CrossRef]

46. Dresselhaus, M.S.; Terrones, M. Carbon-Based Nanomaterials from a Historical Perspective. Proc. IEEE 2013, 101, 1522-1535. [CrossRef]

47. Rodrigues, D.F. Carbon-Based Nanomaterials for Removal of Chemical and Biological Contaminants from Water: A Review of Mechanisms and Applications. Carbon 2015, 91, 122-143.

48. Popov, V.N. Carbon nanotubes: Properties and application. Mater. Sci. Eng. R 2004, 43, 61-102. [CrossRef]

49. Gupta, V.K.; Moradi, O.; Tyagi, I.; Agarwal, S.; Sadegh, H.; Shahryari-Ghoshekandi, R.; Makhlouf, A.S.H.; Goodarzi, M.; Garshasbi, A. Study on the removal of heavy metal ions from industry waste by carbon nanotubes: Effect of the surface modification: A review. Crit. Rev. Environ. Sci. Technol. 2016, 46, 93-118. [CrossRef]

50. Martel, R.; Schmidt, T.; Shea, H.R.; Hertel, T.; Avouris, P. Single- and Multi-Wall Carbon Nanotube Field-Effect Transistors. Appl. Phys. Lett. 1998, 73, 2447-2449. [CrossRef]

51. Yu, G.; Yang, L.; Jiang, G.; Patel, M.; Bafana, A.; Wang, X.; Qiu, B.; Jeffryes, C.; Wei, S.; Guo, Z. Carbon nanotubes, graphene, and their derivatives for heavy metal removal. Adv. Compos. Hybrid Mater. 2018, 1, 56-78. [CrossRef]

52. Lu, H.; Wang, J.; Stoller, M.; Wang, T.; Ying, B.; Hao, H. An overview of nanomaterials for water and wastewater treatment. Adv. Mater. Sci. Eng. 2016, 2016, 1-10. [CrossRef]

53. Yadav, D.K.; Srivastava, S. Carbon nanotubes as adsorbent to remove heavy metal ion $(\mathrm{Mn}+7)$ in wastewater treatment. Mater. Today Proc. 2017, 4, 4089-4094. [CrossRef]

54. Pu, Y.; Yang, X.; Hong, Z.; Wang, D.; Yu, S.; Jie, H. Adsorption and desorption of thallium(I) on multiwalled carbon nanotubes. Chem. Eng. J. 2013, 219, 403-410. [CrossRef]

55. Tang, W.W.; Zeng, G.M.; Gong, J.L.; Liu, Y.; Wang, X.Y.; Liu, Y.Y.; Liu, Z.F.; Chen, L.; Zhang, X.R.; Tu, D.Z. Simultaneous adsorption of atrazine and $\mathrm{Cu}(\mathrm{II})$ from wastewater by magnetic multi-walled carbon nanotube. Chem. Eng. J. 2012, 211-212, 470-478. [CrossRef]

56. Kabbashi, N.A.; Atieh, M.A.; Al-Mamun, A.; Mirghami, M.E.S.; Alam, M.D.Z.; Yahy, N. Kinetic adsorption of application of carbon nanotubes for $\mathrm{Pb}$ (II) removal from aqueous solution. J. Environ. Sci. 2009, 21, 539-544. [CrossRef]

57. Tuzen, M.; Soylak, M. Multiwalled carbon nanotubes for speciation of chromium in environmental samples. J. Hazard. Mater. 2007, 147, 219-225. [CrossRef]

58. Sandeep, A.; Mota, J.P.B.; Massoud, R.A.; Rood, M.J. Theoretical and experimental investigation of morphology and temperature effects on adsorption of organic vapors in single-walled carbon nanotubes. J. Phys. Chem. B 2006, 110, 7640-7647.

59. Kumar, R.; Khan, M.A.; Haq, N. Application of Carbon Nanotubes in Heavy Metals Remediation. Crit. Rev. Environ. Sci. Technol. 2014, 44, 1000-1035. [CrossRef]

60. El-Sheikh, A.H.; Al-Degs, Y.S.; Al-As'Ad, R.M.; Sweileh, J.A. Effect of oxidation and geometrical dimensions of carbon nanotubes on $\mathrm{Hg}(\mathrm{II})$ sorption and preconcentration from real waters. Desalination 2011, 270, 214-220. [CrossRef]

61. Alomar, M.K.; Alsaadi, M.A.; Hayyan, M.; Akib, S.; Ibrahim, M.; Hashim, M.A. Allyl triphenyl phosphonium bromide based DES-functionalized carbon nanotubes for the removal of mercury from water. Chemosphere 2017, 167, 44-52. [CrossRef]

62. Xu, J.; Cao, Z.; Zhang, Y.; Yuan, Z.; Lou, Z.; Xu, X.; Wang, X. A review of functionalized carbon nanotubes and graphene for heavy metal adsorption from water: Preparation, application, and mechanism. Chemosphere 2018, 195, 351. [CrossRef]

63. Zhan, Y.; Hai, H.; Yi, H.; Long, Z.; Wan, X.; Zeng, G. Novel amino-functionalized $\mathrm{Fe}_{3} \mathrm{O}_{4} /$ carboxylic multi-walled carbon nanotubes: One-pot synthesis, characterization and removal for $\mathrm{Cu}(\mathrm{II})$. Russ. J. Appl. Chem. 2016, 89, 1894-1902. [CrossRef]

64. Novoselov, K.S.; Fal'Ko, V.I.; Colombo, L.; Gellert, P.R.; Schwab, M.G.; Kim, K. A roadmap for graphene. Nature 2012, 490, 192-200. [CrossRef] 
65. Gao, W.; Majumder, M.; Alemany, L.B.; Narayanan, T.N.; Ibarra, M.A.; Pradhan, B.K.; Ajayan, P.M. Engineered graphite oxide materials for application in water purification. ACS Appl. Mater. Interfaces 2011, 3, 1821-1826. [CrossRef]

66. Avouris, P.; Dimitrakopoulos, C. Graphene: Synthesis and applications. Mater. Today 2012, 15, 86-97. [CrossRef]

67. Suárez-Iglesias, O.; Collado, S.; Oulego, P.; Díaz, M. Graphene-Family Nanomaterials in Wastewater Treatment Plants. Chem. Eng. J. 2017, 313, 121-135. [CrossRef]

68. Xu, L.; Wang, J. The application of graphene-based materials for the removal of heavy metals and radionuclides from water and wastewater. Crit. Rev. Environ. Sci. Technol. 2017, 47, 1042-1105. [CrossRef]

69. Hou, W.; Yuan, X.; Yan, W.; Huang, H.; Zeng, G.; Yan, L.; Wang, X.; Lin, N.; Yu, Q. Adsorption characteristics and behaviors of graphene oxide for $\mathrm{Zn}$ (II) removal from aqueous solution. Appl. Surf. Sci. 2013, 279, 432-440. [CrossRef]

70. Zhao, G.; Li, J.; Ren, X.; Chen, C.; Wang, X. Few-layered graphene oxide nanosheets as superior sorbents for heavy metal ion pollution management. Environ. Sci. Technol. 2011, 45, 10454-10462. [CrossRef]

71. Arshad, F.; Selvaraj, M.; Zain, J.; Banat, F.; Haija, M.A. Polyethylenimine modified graphene oxide hydrogel composite as an efficient adsorbent for heavy metal ions. Separat. Purif. Technol. 2018, 209, 870-880. [CrossRef]

72. Vilela, D.; Parmar, J.; Zeng, Y.; Zhao, Y.; Sánchez, S. Graphene-Based Microbots for Toxic Heavy Metal Removal and Recovery from Water. Nano Lett. 2016, 16, 2860-2866. [CrossRef]

73. Fan, Z.; Bo, W.; He, S.; Man, R. Preparation of Graphene-Oxide/Polyamidoamine Dendrimers and Their Adsorption Properties toward Some Heavy Metal Ions. J. Chem. Eng. Data 2014, 59, 1719-1726.

74. Li, X.; Zhou, H.; Wu, W.; Wei, S.; Xu, Y.; Kuang, Y. Studies of heavy metal ion adsorption on Chitosan/Sulfydryl-functionalized graphene oxide composites. J. Colloid Interface Sci. 2015, 448, 389-397. [CrossRef]

75. Yilong, W.; Song, L.; Bingdi, C.; Fangfang, G.; Shuili, Y.; Yulin, T. Synergistic removal of Pb(II), Cd(II) and humic acid by $\mathrm{Fe}_{3} \mathrm{O}_{4} @$ mesoporous silica-graphene oxide composites. PLoS ONE 2013, 8, e65634.

76. Musico, Y.L.F.; Santos, C.M.; Dalida, M.L.P.; Rodrigues, D.F. Improved removal of lead(II) from water using a polymer-based graphene oxide nanocomposite. J. Mater. Chem. A 2013, 1, 3789-3796. [CrossRef]

77. Kumar, S.; Nair, R.R.; Pillai, P.B.; Gupta, S.N.; Iyengar, M.A.; Sood, A.K. Graphene oxide- $\mathrm{MnFe}_{2} \mathrm{O}_{4}$ magnetic nanohybrids for efficient removal of lead and arsenic from water. ACS Appl. Mater. Interfaces 2014, 6, 17426. [CrossRef]

78. Cui, L.; Wang, Y.; Liang, G.; Hu, L.; Yan, L.; Qin, W.; Du, B. EDTA functionalized magnetic graphene oxide for removal of $\mathrm{Pb}(\mathrm{II}), \mathrm{Hg}(\mathrm{II})$ and $\mathrm{Cu}(\mathrm{II})$ in water treatment: Adsorption mechanism and separation property. Chem. Eng. J. 2015, 281, 1-10. [CrossRef]

79. Tan, M.; Liu, X.; Li, W.; Li, H. Enhancing Sorption Capacities for Copper(II) and Lead(II) under Weakly Acidic Conditions by l-Tryptophan-Functionalized Graphene Oxide. J. Chem. Eng. Data 2015, 60, 1469-1475. [CrossRef]

80. Hai, T.X.; Jian, H.C.; Xue, S.; Yi, H.H.; Zhen, B.S.; Shi, R.H.; Wen, W.; Li, S.X.; Hong, X.G.; Wen, B.W. NH 2 -rich polymer/graphene oxide use as a novel adsorbent for removal of $\mathrm{Cu}(\mathrm{II})$ from aqueous solution. Chem. Eng. J. 2015, 263, 280-289.

81. Chauke, V.P.; Maity, A.; Chetty, A. High-performance towards removal of toxic hexavalent chromium from aqueous solution using graphene oxide-alpha cyclodextrin-polypyrrole nanocomposites. J. Mol. Liquids 2015, 211, 71-77. [CrossRef]

82. Zhang, K.; Li, H.; Xu, X.; Yu, H. Synthesis of reduced graphene oxide/NiO nanocomposites for the removal of $\mathrm{Cr}(\mathrm{VI})$ from aqueous water by adsorption. Microporous Mesoporous Mater. 2018, 255, 7-14. [CrossRef]

83. Zhao, D.; Chen, L.L.; Xu, M.; Feng, S.; Chen, C. Amino Siloxane Oligomer Modified Graphene Oxide Composite for the Efficient Capture of $\mathrm{U}(\mathrm{VI})$ and $\mathrm{Eu}(\mathrm{III})$ from Aqueous Solution. ACS Sustain. Chem. 2017, 5, 10290-10297. [CrossRef]

84. Najafabadi, H.H.; Irani, M.; Rad, L.R.; Haratameh, A.H.; Haririan, I. Removal of $\mathrm{Cu}^{2+}, \mathrm{Pb}^{2+}$ and $\mathrm{Cr}^{6+}$ from aqueous solutions using a chitosan/graphene oxide composite nanofibrous adsorbent. RSC Adv. 2015, 5, 22390. [CrossRef]

85. Mahmoud, M.E.; Fekry, N.A.; El-Latif, M.M.A. Nanocomposites of nanosilica-immobilized-nanopolyaniline and crosslinked nanopolyaniline for removal of heavy metals. Chem. Eng. J. 2016, 304, 679-691. [CrossRef] 
86. Kotsyuda, S.S.; Tomina, V.V.; Zub, Y.L.; Furtat, I.M.; Melnyk, I.V. Bifunctional silica nanospheres with 3-aminopropyl and phenyl groups. Synthesis approach and prospects of their applications. Appl. Surf. Sci. 2017, 420, 782-791. [CrossRef]

87. Najafi, M.; Yousefi, Y.; Rafati, A.A. Synthesis, characterization and adsorption studies of several heavy metal ions on amino-functionalized silica nano hollow sphere and silica gel. Separat. Purif. Technol. 2012, 85, 193-205. [CrossRef]

88. Pogorilyi, R.P.; Melnyk, I.A.; Zub, Y.L.; Carlson, S.; Daniel, G.; Svedlindh, P.; Seisenbaeva, G.A.; Kessler, V.G. New product from old reaction: Uniform magnetite nanoparticles from iron-mediated synthesis of alkali iodides and their protection from leaching in acidic media. RSC Adv. 2014, 4, 22606-22612. [CrossRef]

89. Srinivasan, N.R.; Shankar, P.A.; Bandyopadhyaya, R. Plasma treated activated carbon impregnated with silver nanoparticles for improved antibacterial effect in water disinfection. Carbon 2013, 57, 1-10. [CrossRef]

90. Bokare, V.; Jung, J.L.; Chang, Y.Y.; Chang, Y.S. Reductive dechlorination of octachlorodibenzo-p-dioxin by nanosized zero-valent zinc: Modeling of rate kinetics and congener profile. J. Hazard. Mater. 2013, 250-251, 397-402. [CrossRef]

91. O'Carroll, D.; Sleep, B.; Krol, M.; Boparai, H.; Kocur, C. Nanoscale zero valent iron and bimetallic particles for contaminated site remediation. Adv. Water Resour. 2013, 51, 104-122. [CrossRef]

92. Liu, T.; Wang, Z.L.; Sun, Y. Manipulating the morphology of nanoscale zero-valent iron on pumice for removal of heavy metals from wastewater. Chem. Eng. J. 2015, 263, 55-61. [CrossRef]

93. Zhen, Z.; Wei, H.Z.; Li, L.W.; Hua, X.X. Synchronous Treatment of Heavy Metal Ions and Nitrate by Zero-valent Iron. Huan Jing Ke Xue 2009, 30, 775-779.

94. Seyedi, S.M.; Rabiee, H.; Shahabadi, S.M.S.; Borghei, S.M. Synthesis of Zero-valent Iron Nanoparticles via Electrical Wire Explosion for Efficient Removal of Heavy Metals: Water. Clean-Soil Air Water 2016, 45, 1600139. [CrossRef]

95. Cundy, A.B.; Hopkinson, L.; Whitby, R.L. Use of iron-based technologies in contaminated land and groundwater remediation: A review. Sci. Total Environ. 2008, 400, 42-51. [CrossRef]

96. Huang, P.; Ye, Z.; Xie, W.; Chen, Q.; Li, J.; Xu, Z.; Yao, M. Rapid magnetic removal of aqueous heavy metals and their relevant mechanisms using nanoscale zero valent iron (nZVI) particles. Water Res. 2013, 47, 4050-4058. [CrossRef]

97. Wei, W.; Hua, Y.; Li, S.; Yan, W.; Zhang, W.X. Removal of Pb(II) and Zn(II) using lime and nanoscale zero-valent iron (nZVI): A comparative study. Chem. Eng. J. 2016, 304, 79-88.

98. Li, X.Q.; Zhang, W.X. Sequestration of Metal Cations with Zerovalent Iron Nanoparticles-A Study with High Resolution X-ray Photoelectron Spectroscopy (HR-XPS). J. Phys. Chem. C 2007, 111, 6939-6946. [CrossRef]

99. Tratnyek, P.G.; Sarathy, V.; Nurmi, J.; Baer, D.R.; Amonette, J.E.; Chan, L.C.; Penn, R.L.; Reardon, E.J. Aging of Iron Nanoparticles in Water: Effects on Structure and Reactivity. J. Phys. Chem. C 2008, 112, 2286-2293.

100. Fu, F.; Dionysiou, D.D.; Hong, L. The use of zero-valent iron for groundwater remediation and wastewater treatment: A review. J. Hazard. Mater. 2014, 267, 194-205. [CrossRef]

101. Huang, D.L.; Chen, G.M.; Zeng, G.M.; Xu, P.; Yan, M.; Lai, C.; Zhang, C.; Li, N.J.; Cheng, M.; He, X.X. Synthesis and Application of Modified Zero-Valent Iron Nanoparticles for Removal of Hexavalent Chromium from Wastewater. Water Air Soil Pollut. 2015, 226, 375. [CrossRef]

102. Su, Y.; Adeleye, A.S.; Huang, Y.; Sun, X.; Dai, C.; Zhou, X.; Zhang, Y.; Keller, A.A. Simultaneous removal of cadmium and nitrate in aqueous media by nanoscale zerovalent iron (nZVI) and Au doped nZVI particles. Water Res. 2014, 63, 102-111. [CrossRef]

103. Zarime, N.A.; Wan, Z.W.Y.; Jamil, H. Removal of heavy metals using bentonite supported nano-zero valent iron particles. In Proceedings of the Ukm Fst Postgraduate Colloquium: University Kebangsaan Malaysia, Faculty of Science \& Technology Postgraduate Colloquium, Univ Kebangsaan Malaysia, Fac Sci \& Technol, Selangor, Malaysia, 12-13 July 2017.

104. Zhang, W. Nanoscale Iron Particles for Environmental Remediation: An Overview. J. Nanopart. Res. 2003, 5, 323-332. [CrossRef]

105. Morris, T.; Copeland, H.; Mclinden, E.; Wilson, S.; Szulczewski, G. The Effects of Mercury Adsorption on the Optical Response of Size-Selected Gold and Silver Nanoparticles. Langmuir 2002, 18, 7261-7264. [CrossRef]

106. Fan, Y.; Liu, Z.; Wang, L.E.; Zhan, J. Synthesis of Starch-Stabilized Ag Nanoparticles and $\mathrm{Hg}^{2+}$ Recognition in Aqueous Media. Nano Scale Res. Lett. 2009, 4, 1230-1235. [CrossRef] 
107. Pradhan, N.; Pal, A.; Pal, T. Silver nanoparticle catalyzed reduction of aromatic nitro compounds. Colloids Surf. A 2002, 196, 247-257. [CrossRef]

108. Sumesh, E.; Bootharaju, M.S.; Anshup; Pradeep, T. A practical silver nanoparticle-based adsorbent for the removal of $\mathrm{Hg}^{2+}$ from water. J. Hazard. Mater. 2011, 189, 450-457. [CrossRef]

109. Zhang, Y.; Bing, W.; Hui, X.; Hui, L.; Wang, M.; He, Y.; Pan, B. Nanomaterials-enabled water and wastewater treatment. Nanoimpact 2016, 3-4, 22-39. [CrossRef]

110. Lisha, K.P.; Anshup; Pradeep, T. Towards a practical solution for removing inorganic mercury from drinking water using gold nanoparticles. Gold Bull. 2009, 42, 144-152. [CrossRef]

111. Ojea-Jiménez, I.; López, X.; Arbiol, J.; Puntes, V. Citrate-coated gold nanoparticles as smart scavengers for mercury(II) removal from polluted waters. ACS Nano 2012, 6, 2253. [CrossRef]

112. Sneed; Cannon, M. Comprehensive inorganic chemistry. Nature 1958, 181, 1428. [CrossRef]

113. Saharan, P.; Chaudhary, G.R.; Mehta, S.K.; Umar, A. Removal of water contaminants by iron oxide nanomaterials. J. Nanosci. Nanotechnol. 2014, 14, 627-643. [CrossRef]

114. Birch, F. Density and Composition of Mantle and Core. J. Geophys. Res. 1964, 69, 4377-4388. [CrossRef]

115. Massalimov, I.A.; Il'Yasova, R.R.; Musavirova, L.R.; Samsonov, M.R.; Mustafin, A.G. Use of micrometer hematite particles and nanodispersed goethite as sorbent for heavy metals. Russ. J. Appl. Chem. 2014, 87, 1456-1463. [CrossRef]

116. Sun, Y.B.; Wang, Q.; Yang, S.T.; Sheng, G.D.; Guo, Z.Q. Characterization of nano-iron oxyhydroxides and their application in $\mathrm{UO}_{2}{ }^{2+}$ removal from aqueous solutions. J. Radioanal. Nuclear Chem. 2011, 290, 643-648. [CrossRef]

117. Chen, Y.H.; Li, F.A. Kinetic study on removal of copper(II) using goethite and hematite nano-photocatalysts. J. Colloid Interface Sci. 2010, 347, 277-281. [CrossRef]

118. Khezami, L.; M'Hamed, M.O.; Lemine, O.M.; Bououdina, M.; Bessadokjemai, A. Milled goethite nanocrystalline for selective and fast uptake of cadmium ions from aqueous solution. Desalinat. Water Treat. 2016, 57, 1-9. [CrossRef]

119. Leiviskä, T.; Khalid, M.K.; Sarpola, A.; Tanskanen, J. Removal of vanadium from industrial wastewater using iron sorbents in batch and continuous flow pilot systems. J. Environ. Manag. 2017, 190, 231-242. [CrossRef]

120. Forbes, E.A.; Posner, A.M.; Quirk, J.P. The specific adsorption of divalent $\mathrm{Cd}, \mathrm{Co}, \mathrm{Cu}, \mathrm{Pb}, \mathrm{AND} \mathrm{Zn}$ on goethite. Eur. J. Soil Sci. 2010, 27, 154-166. [CrossRef]

121. Li, Y.; Fan, Q.; Wu, W. Sorption of Th(IV) on goethite: Effects of pH, ionic strength, FA and phosphate. J. Radioanal. Nuclear Chem. 2011, 289, 865-871.

122. Tadic, M.; Panjan, M.; Damnjanovic, V.; Milosevic, I. Magnetic properties of hematite $\left(\alpha-\mathrm{Fe}_{2} \mathrm{O}_{3}\right)$ nanoparticles prepared by hydrothermal synthesis method. Appl. Surf. Sci. 2014, 320, 183-187. [CrossRef]

123. Chen, L.; Wang, G.; Mathur, G.N.; Varadan, V.K. Size and Shape Dependence of the Electrochemical Properties of Hematite Nanoparticles and Their Applications in Lithium Ion Batteries. Proc. SPIE 2012, 38. [CrossRef]

124. Guo, H.; Barnard, A.S. Can Hematite Nanoparticles be an Environmental Indicator? Energy Environ. Sci. 2013, 6, 561-569. [CrossRef]

125. Cuong, N.D.; Hoa, N.D.; Hoa, T.T.; Khieu, D.Q.; Quang, D.T.; Quang, V.V.; Hieu, N.V. Nanoporous hematite nanoparticles: Synthesis and applications for benzylation of benzene and aromatic compounds. J. Alloys Compd. 2014, 582, 83-87. [CrossRef]

126. Ahmed, M.A.; Ali, S.M.; El-Dek, S.I.; Galal, A. Magnetite-hematite nanoparticles prepared by green methods for heavy metal ions removal from water. Mater. Sci. Eng. B 2013, 178, 744-751. [CrossRef]

127. Adegoke, H.I.; Amooadekola, F.; Fatoki, O.S.; Ximba, B.J. Adsorption of Cr(VI) on synthetic hematite $\left(\alpha-\mathrm{Fe}_{2} \mathrm{O}_{3}\right)$ nanoparticles of different morphologies. Korean J. Chem. Eng. 2014, 31, 142-154. [CrossRef]

128. Dickson, D.; Liu, G.; Cai, Y. Adsorption kinetics and isotherms of arsenite and arsenate on hematite nanoparticles and aggregates. J. Environ. Manag. 2017, 186, 261-267. [CrossRef]

129. Shipley; Heather, J.; Engates; Karen, E.; Grover; Valerie, A. Removal of $\mathrm{Pb}(\mathrm{II}), \mathrm{Cd}(\mathrm{II}), \mathrm{Cu}(\mathrm{II})$, and Zn(II) by hematite nanoparticles: Effect of sorbent concentration, $\mathrm{pH}$, temperature, and exhaustion. Environ. Sci. Pollut. Res. Int. 2013, 20, 1727-1736. [CrossRef]

130. Kefeni, K.K.; Msagati, T.A.M.; Nkambule, T.T.I.; Mamba, B.B. Synthesis and application of hematite nanoparticles for acid mine drainage treatment. J. Environ. Chem. Eng. 2018, 6, 1865-1874. [CrossRef] 
131. Akhtarkhavari, A. Removal, preconcentration and determination of Mo(VI) from water and wastewater samples using maghemite nanoparticles. Colloids Surf. A 2009, 346, 52-57.

132. Jing, H.; Guohua, C.; Lo, I.M.C. Removal and recovery of $\mathrm{Cr}(\mathrm{VI})$ from wastewater by maghemite nanoparticles. Water Res. 2005, 39, 4528-4536.

133. Etale, A.; Tutu, H.; Drake, D.C. The effect of silica and maghemite nanoparticles on remediation of $\mathrm{Cu}(\mathrm{II})-$, Mn(II)- and U(VI)-contaminated water by Acutodesmus sp. J. Appl. Phycol. 2016, 28, 251-260. [CrossRef]

134. Tuutijärvi, T.; Lu, J.; Sillanpää, M.; Chen, G. As(V) adsorption on maghemite nanoparticles. J. Hazard. Mater. 2009, 166, 1415-1420. [CrossRef]

135. Akhbarizadeh, R.; Shayestefar, M.R.; Darezereshki, E. Competitive Removal of Metals from Wastewater by Maghemite Nanoparticles: A Comparison Between Simulated Wastewater and AMD. Mine Water Environ. 2014, 33, 89-96. [CrossRef]

136. Rajput, S.; Singh, L.P.; Jr, C.U.P.; Mohan, D. Lead $\left(\mathrm{Pb}^{2+}\right)$ and copper $\left(\mathrm{Cu}^{2+}\right)$ remediation from water using Superparamagnetic maghemite $\left(\gamma-\mathrm{Fe}_{2} \mathrm{O}_{3}\right)$ nanoparticles synthesized by Flame Spray Pyrolysis (FSP). J. Colloid Interface Sci. 2017, 492, 176-190. [CrossRef]

137. Madrakian, T.; Afkhami, A.; Zadpour, B.; Ahmadi, M. New synthetic mercaptoethylamino homopolymer-modified maghemite nanoparticles for effective removal of some heavy metal ions from aqueous solution. J. Ind. Eng. Chem. 2015, 21, 1160-1166. [CrossRef]

138. Takafuji, M.; Ide, S.; Ihara, H.; Xu, Z.H. Preparation of poly(1-vinylimidazole)-grafted magnetic nanoparticles and their application for removal of metal ions. Chem. Mater. 2004, 16, 1977-1983. [CrossRef]

139. Song, J.; Kong, H.; Jang, J. Adsorption of heavy metal ions from aqueous solution by polyrhodanine-encapsulated magnetic nanoparticles. J. Colloid Interface Sci. 2011, 359, 505-511. [CrossRef]

140. Chávez-Guajardo, A.E.; Medina-Llamas, J.C.; Maqueira, L.; Andrade, C.A.S.; Alves, K.G.B.; Melo, C.P.D. Efficient removal of $\mathrm{Cr}(\mathrm{VI})$ and $\mathrm{Cu}(\mathrm{II})$ ions from aqueous media by use of polypyrrole/maghemite and polyaniline/maghemite magnetic nanocomposites. Chem. Eng. J. 2015, 281, 826-836. [CrossRef]

141. Hao, Y.M.; Man, C.; Hu, Z.B. Effective removal of $\mathrm{Cu}(\mathrm{II})$ ions from aqueous solution by amino-functionalized magnetic nanoparticles. J. Hazard. Mater. 2010, 184, 392-399. [CrossRef]

142. Watts, M.P.; Coker, V.S.; Parry, S.A.; Pattrick, R.A.D.; Thomas, R.A.P.; Kalin, R.; Lloyd, J.R. Biogenic nano-magnetite and nano-zero valent iron treatment of alkaline $\mathrm{Cr}(\mathrm{VI})$ leachate and chromite ore processing residue. Appl. Geochem. 2015, 54, 27-42. [CrossRef]

143. Shan, C.; Ma, Z.; Tong, M.; Ni, J. Removal of $\mathrm{Hg}$ (II) by poly(1-vinylimidazole)-grafted $\mathrm{Fe}_{3} \mathrm{O}_{4} @ \mathrm{SiO}_{2}$ magnetic nanoparticles. Water Res. 2015, 69, 252-260. [CrossRef]

144. Mahmoud, M.E.; Abdelwahab, M.S.; Abdou, A.E.H. Enhanced removal of lead and cadmium from water by $\mathrm{Fe}_{3} \mathrm{O}_{4}$-cross linked-O-phenylenediamine nano-composite. Sep. Sci. Technol. 2016, 51, 237-247. [CrossRef]

145. Giraldo, L.; Erto, A.; Moreno-Piraján, J.C. Magnetite nanoparticles for removal of heavy metals from aqueous solutions: Synthesis and characterization. Adsorption 2013, 19, 465-474. [CrossRef]

146. Hu, H.; Wang, Z.; Pan, L. Synthesis of monodisperse $\mathrm{Fe}_{3} \mathrm{O}_{4}$ @silica core-shell microspheres and their application for removal of heavy metal ions from water. J. Alloys Compod. 2010, 492, 656-661. [CrossRef]

147. Tan, Y.Q.; Chen, M.; Hao, Y.M. High efficient removal of $\mathrm{Pb}(\mathrm{II})$ by amino-functionalized $\mathrm{Fe}_{3} \mathrm{O}_{4}$ magnetic nano-particles. Chem. Eng. J. 2012, 191, 104-111. [CrossRef]

148. Shi, J.; Li, H.Y.; Lu, H.G.; Zhao, X.W. Use of Carboxyl Functional Magnetite Nanoparticles as Potential Sorbents for the Removal of Heavy Metal Ions from Aqueous Solution. J. Chem. Eng. Data 2015, 60, 2035-2041. [CrossRef]

149. Pan, S.D.; Shen, H.Y.; Xu, Q.H.; Luo, J.; Hu, M.Q. Surface mercapto engineered magnetic $\mathrm{Fe}_{3} \mathrm{O}_{4}$ nanoadsorbent for the removal of mercury from aqueous solutions. J. Colloid Interface Sci. 2012, 365, 204-212. [CrossRef] [PubMed]

150. Christian, S.; Robin, E.; Robert, Z.; Artur, F.; Hauke, K.; Christopher, W.; Johannes, O.; Jan-Philip, M.; Theo, S.; Kornelius, N. Polymer-assisted self-assembly of superparamagnetic iron oxide nanoparticles into well-defined clusters: Controlling the collective magnetic properties. Langmuir ACS J. Surf. Colloids 2014, 30, 11190-11196.

151. Baghani, A.N.; Mahvi, A.H.; Gholami, M.; Rastkari, N.; Delikhoon, M. One-Pot synthesis, characterization and adsorption studies of amine-functionalized magnetite nanoparticles for removal of $\mathrm{Cr}(\mathrm{VI})$ and $\mathrm{Ni}(\mathrm{II})$ ions from aqueous solution: Kinetic, isotherm and thermodynamic studies. J. Environ. Health Sci. 2016, 14, 11. [CrossRef] [PubMed] 
152. Madrakian, T.; Afkhami, A.; Zolfigol, M.A.; Ahmadi, M.; Koukabi, N. Application of Modified Silica Coated Magnetite Nanoparticles for Removal of Iodine from Water Samples. Nano-Micro Lett. 2012, 4, 57-63. [CrossRef]

153. Adeli, M.; Yamini, Y.; Faraji, M. Removal of copper, nickel and zinc by sodium dodecyl sulphate coated magnetite nanoparticles from water and wastewater samples. Arab. J. Chem. 2017, 10, S514-S521. [CrossRef]

154. Magnet, C.; Lomenech, C.; Hurel, C.; Reilhac, P.; Giulieri, F.; Chaze, A.M.; Persello, J.; Kuzhir, P. Adsorption of nickel ions by oleate-modified magnetic iron oxide nanoparticles. Environ. Sci. Pollut. R 2017, 24, 7423-7435. [CrossRef] [PubMed]

155. Madrakian, T.; Afkhami, A.; Rezvani-jalal, N.; Ahmadi, M. Removal and preconcentration of lead(II), cadmium(II) and chromium(III) ions from wastewater samples using surface functionalized magnetite nanoparticles. J. Iran Chem. Soc. 2014, 11, 489-498. [CrossRef]

156. Behbahani, N.S.; Rostamizadeh, K.; Yaftian, M.R.; Zamani, A.; Ahmadi, H. Covalently modified magnetite nanoparticles with PEG: Preparation and characterization as nano-adsorbent for removal of lead from wastewater. J. Environ. Health Sci. 2014, 12, 103. [CrossRef] [PubMed]

157. Rahbar, N.; Jahangiri, A.; Boumi, S.; Khodayar, M.J. Mercury Removal from Aqueous Solutions with Chitosan-Coated Magnetite Nanoparticles Optimized Using the Box-Behnken Design. Jundishapur J. Nat. Pharm. Prod. 2014, 9, e15913. [CrossRef] [PubMed]

158. Bagtash, M.; Yamini, Y.; Tahmasebi, E.; Zolgharnein, J.; Dalirnasab, Z. Magnetite nanoparticles coated with tannic acid as a viable sorbent for solid-phase extraction of $\mathrm{Cd}^{2+}, \mathrm{Co}^{2+}$ and $\mathrm{Cr}^{3+}$. Microchim. Acta 2016, 183, 449-456. [CrossRef]

159. Huang, X.; Yang, J.; Wang, J.; Bi, J.; Xie, C.; Hao, H. Design and synthesis of core-shell Fe $\mathrm{O}_{4} @ @^{\mathrm{PTMT}}$ composite magnetic microspheres for adsorption of heavy metals from high salinity wastewater. Chemosphere 2018, 206, 513. [CrossRef] [PubMed]

160. Fan, M.; Boonfueng, T.; Xu, Y.; Axe, L.; Tyson, T.A. Modeling Pb sorption to microporous amorphous oxides as discrete particles and coatings. J. Colloid Interface Sci. 2005, 281, 39-48. [CrossRef]

161. Hui, Q.; Shujuan, Z.; Bingcai, P.; Weiming, Z.; Lu, L. Effect of sulfate on Cu(II) sorption to polymer-supported nano-iron oxides: Behavior and XPS study. J. Colloid Interface Sci. 2012, 366, 37-43.

162. Singh, S.K.; Subramanian, V.; Gibbs, R.J. Hydrous FE and MN oxides-Scavengers of heavy metals in the aquatic environment. Crit. Rev. Environ. Control 1984, 14, 33-90. [CrossRef]

163. Hui, Q.; Zhang, S.; Pan, B.; Zhang, W.; Lu, L. Oxalate-promoted dissolution of hydrous ferric oxide immobilized within nanoporous polymers: Effect of ionic strength and visible light irradiation. Chem. Eng. J. 2013, 232, 167-173.

164. Zhang, Y.; Li, Z. Heavy metals removal using hydrogel-supported nanosized hydrous ferric oxide: Synthesis, characterization, and mechanism. Sci. Total Environ. 2017, 580, 776-786. [CrossRef] [PubMed]

165. Byungryul, A.; Steinwinder, T.R.; Dongye, Z. Selective removal of arsenate from drinking water using a polymeric ligand exchanger. Water Res. 2005, 39, 4993-5004.

166. Huo, L.; Zeng, X.; Su, S.; Bai, L.; Wang, Y. Enhanced removal of As(V) from aqueous solution using modified hydrous ferric oxide nanoparticles. Sci. Rep. 2017, 7, 40765. [CrossRef] [PubMed]

167. Lockwood, R.A.; Chen, K.Y. Adsorption of mercury(II) by hydrous manganese oxides. Environ. Sci. Technol. 1973, 7, 1028-1034. [CrossRef] [PubMed]

168. Mukherjee, J.; Ramkumar, J.; Shukla, R.; Tyagi, A.K. Sorption characteristics of nano manganese oxide: Efficient sorbent for removal of metal ions from aqueous streams. J. Radioanal. Nuclear Chem. 2013, 297, 49-57. [CrossRef]

169. Wang, X.; Huang, K.; Chen, Y.; Liu, J.; Chen, S.; Cao, J.; Mei, S.; Zhou, Y.; Jing, T. Preparation of dumbbell manganese dioxide/gelatin composites and their application in the removal of lead and cadmium ions. J. Hazard. Mater. 2018, 350, 46-54. [CrossRef] [PubMed]

170. Huangfu, X.; Jin, J.; Lu, X.; Wang, Y.; Liu, Y.; Pang, S.Y.; Cheng, H.; Xiang, Z.; Ma, J. Adsorption and Oxidation of Thallium(I) by a Nanosized Manganese Dioxide. Water Air Soil Pollut. 2015, 226, 2272. [CrossRef]

171. Abdullah, J.A.; Lafi, A.G.A.; Amin, Y.; Alnama, T. A Styrofoam-nano manganese oxide based composite: Preparation and application for the treatment of wastewater. Appl. Radiat. Isotopes 2018, 136, 73. [CrossRef] [PubMed] 
172. Kim, E.J.; Lee, C.S.; Chang, Y.Y.; Chang, Y.S. Hierarchically structured manganese oxide-coated magnetic nanocomposites for the efficient removal of heavy metal ions from aqueous systems. Appl. Mater. Interfaces 2013, 5, 9628-9634. [CrossRef] [PubMed]

173. Lisha, K.P.; Maliyekkal, S.M.; Pradeep, T. Manganese dioxide nanowhiskers: A potential adsorbent for the removal of $\mathrm{Hg}(\mathrm{II})$ from water. Chem. Eng. J. 2010, 160, 432-439. [CrossRef]

174. Sposito, G. On the surface complexation model of the oxide-aqueous solution interface. J. Colloid Interface Sci. 1983, 91, 329-340. [CrossRef]

175. Wan, S.; Wu, J.; Zhou, S.; Rui, W.; Gao, B.; Feng, H. Enhanced lead and cadmium removal using biochar-supported hydrated manganese oxide (HMO) nanoparticles: Behavior and mechanism. Sci. Total Environ. 2018, 616-617, 1298-1306. [CrossRef]

176. Kumar, K.Y.; Muralidhara, H.B.; Nayaka, Y.A.; Balasubramanyam, J.; Hanumanthappa, H. Low-cost synthesis of metal oxide nanoparticles and their application in adsorption of commercial dye and heavy metal ion in aqueous solution. Powder Technol. 2013, 246, 125-136. [CrossRef]

177. Rafiq, Z.; Nazir, R.; Durr-e-Shahwar; Shah, M.R.; Ali, S. Utilization of magnesium and zinc oxide nano-adsorbents as potential materials for treatment of copper electroplating industry wastewater. J. Environ. Chem. Eng. 2014, 2, 642-651. [CrossRef]

178. Hadadian, M.; Goharshadi, E.K.; Fard, M.M.; Ahmadzadeh, H. Synergistic effect of graphene nanosheets and zinc oxide nanoparticles for effective adsorption of $\mathrm{Ni}(\mathrm{II})$ ions from aqueous solutions. Appl. Phys. A 2018, 124, 239. [CrossRef]

179. Sheela, T.; Nayaka, Y.A.; Viswanatha, R.; Basavanna, S.; Venkatesha, T.G. Kinetics and thermodynamics studies on the adsorption of $\mathrm{Zn}(\mathrm{II}), \mathrm{Cd}(\mathrm{II})$ and $\mathrm{Hg}$ (II) from aqueous solution using zinc oxide nanoparticles. Powder Technol. 2012, 217, 163-170. [CrossRef]

180. Ghiloufi, I.; Mir, L.E. Preparation and characterization of nanoporous resin for heavy metal removal from aqueous solution. J. Water Supply Res. Technol.-Aqua. 2015, 64, 316-325. [CrossRef]

181. Somu, P.; Paul, S. Casein based biogenic-synthesized zinc oxide nanoparticles simultaneously decontaminate heavy metals, dyes, and pathogenic microbes: A rational strategy for wastewater treatment. J. Chem. Technol. Biotechnol. 2018. [CrossRef]

182. Anandan, S.; Kathiravan, K.; Murugesan, V.; Ikuma, Y. Anionic $\mathrm{IO}_{3}$ - non-metal doped $\mathrm{TiO}_{2}$ nanoparticles for the photocatalytic degradation of hazardous pollutant in water. Catal. Commun. 2009, 10, 1014-1019. [CrossRef]

183. Skubal, L.R.; Meshkov, N.K.; Rajh, T.; Thurnauer, M. Cadmium removal from water using thiolactic acid-modified titanium dioxide nanoparticles. J. Photochem. Photobiol. A Chem. 2002, 148, 393-397. [CrossRef]

184. Seisenbaeva, G.A.; Daniel, G.; Nedelec, J.M.; Gun'Ko, Y.K.; Kessler, V.G. High surface area ordered mesoporous nano-titania by a rapid surfactant-free approach. J. Mater. Chem. 2012, 22, 20374-20380. [CrossRef]

185. Malhat, F.M.; Youssef, A. Selective removal of heavy metal from drinking water using titanium oxide nanowire. Macromol. Symposia 2014, 337, 96-101.

186. Deedar, N.; Irfan, A.; Qazi, I.A. Evaluation of the adsorption potential of titanium dioxide nanoparticles for arsenic removal. J. Environ. Sci. 2009, 21, 402-408.

187. Baysal, A.; Kuznek, C.; Ozcan, M. Starch coated titanium dioxide nanoparticles as a challenging sorbent to separate and preconcentrate some heavy metals using graphite furnace atomic absorption spectrometry. Int. J. Environ. Anal. Chem. 2018, 98. [CrossRef]

188. Mahmoud, M.E.; Ali, S.A.A.A.; Elweshahy, S.M.T. Microwave functionalization of titanium oxide nanoparticles with chitosan nanolayer for instantaneous microwave sorption of $\mathrm{Cu}(\mathrm{II})$ and $\mathrm{Cd}(\mathrm{II})$ from water. Int. J. Biol. Macromol. 2018, 111, 393-399. [CrossRef]

189. Du, P.; Cameiro, J.T.; Moulijn, J.A.; Mul, G. A novel photocatalytic monolith reactor for multiphase heterogeneous photocatalysis. Appl. Catal. A Gen. 2008, 334, 119-128. [CrossRef]

190. Giles, D.E.; Mohapatra, M.; Issa, T.B.; Anand, S.; Singh, P. Iron and aluminium based adsorption strategies for removing arsenic from water. J. Environ. Manag. 2011, 92, 3011-3022. [CrossRef]

191. Prabhakar, R.; Samadder, S.R. Low cost and easy synthesis of aluminium oxide nanoparticles for arsenite removal from groundwater: A complete batch study. J. Mol. Liquids 2018, 250, 192-201. [CrossRef]

192. Xie, Y.; Kocaefe, D.; Kocaefe, Y.; Cheng, J.; Liu, W. The Effect of Novel Synthetic Methods and Parameters Control on Morphology of Nano-alumina Particles. Nanoscale Res. Lett. 2016, 11, 259. [CrossRef] 
193. Saadi, Z.; Saadi, R.; Fazaeli, R. Fixed-bed adsorption dynamics of $\mathrm{Pb}(\mathrm{II})$ adsorption from aqueous solution using nanostructured $\gamma$-alumina. J. Nanostruct. Chem. 2013, 3, 1-8. [CrossRef]

194. Tabesh, S.; Davar, F.; Reza Loghman-Estarki, M. Preparation of $\gamma-\mathrm{Al}_{2} \mathrm{O}_{3}$ Nanoparticles Using Modified Sol-Gel Method and Its Use for the Adsorption of Lead and Cadmium Ions. J. Alloys Compd. 2018, 730, 441-449. [CrossRef]

195. Stietiya, M.H.; Wang, J.J. Zinc and cadmium adsorption to aluminum oxide nanoparticles affected by naturally occurring ligands. J. Environ. Qual. 2014, 43, 498. [CrossRef] [PubMed]

196. Wang, X.; Zhan, C.; Kong, B.; Zhu, X.; Liu, J.; Xu, W.; Cai, W.; Wang, H. Self-curled coral-like $\gamma-\mathrm{Al}_{2} \mathrm{O}_{3}$ nanoplates for use as an adsorbent. J. Colloid Interface Sci. 2015, 453, 244-251. [CrossRef] [PubMed]

197. Patra, A.K.; Dutta, A.; Bhaumik, A. Self-assembled mesoporous $\gamma-\mathrm{Al}_{2} \mathrm{O}_{3}$ spherical nanoparticles and their efficiency for the removal of arsenic from water. J. Hazard. Mater. 2012, 201, 170-177. [CrossRef] [PubMed]

198. Mahdavi, S.; Jalali, M.; Afkhami, A. Heavy metals removal from aqueous solutions by $\mathrm{Al}_{2} \mathrm{O}_{3}$ nanoparticles modified with natural and chemical modifiers. Clean Technol. Environ. Policy 2015, 17, 85-102. [CrossRef]

199. Poursani, A.S.; Nilchi, A.; Hassani, A.H.; Shariat, M.; Nouri, J. A novel method for synthesis of nano- $\gamma-\mathrm{Al}_{2} \mathrm{O}_{3}$ : Study of adsorption behavior of chromium, nickel, cadmium and lead ions. Int. J. Environ. Sci. Technol. 2015, 12, 2003-2014. [CrossRef]

200. Cai, Y.; Li, C.; Dan, W.; Wei, W.; Tan, F.; Wang, X.; Wong, P.K.; Qiao, X. Highly active MgO nanoparticles for simultaneous bacterial inactivation and heavy metal removal from aqueous solution. Chem. Eng. J. 2016, 312, 158-166. [CrossRef]

201. Stoimenov, P.K.; Klinger, R.L.; Marchin, G.L.; Klabunde, K.J. Metal oxide nanoparticles as bactericidal agents. Langmuir 2002, 18, 6679-6686. [CrossRef]

202. Mahdavi, S.; Jalali, M.; Afkhami, A. Heavy metals removal from aqueous solutions using $\mathrm{TiO}_{2}, \mathrm{MgO}$, and $\mathrm{Al}_{2} \mathrm{O}_{3}$ nanoparticles. Chem. Eng. Commun. 2013, 200, 448-470. [CrossRef]

203. Madzokere, T.C.; Karthigeyan, A. Heavy Metal Ion Effluent Discharge Containment Using Magnesium Oxide (MgO) Nanoparticles. Mater. Today 2017, 4, 9-18. [CrossRef]

204. Xiong, C.; Wang, W.; Tan, F.; Luo, F.; Chen, J.; Qiao, X. Investigation on the efficiency and mechanism of $\mathrm{Cd}(\mathrm{II})$ and $\mathrm{Pb}(\mathrm{II})$ removal from aqueous solutions using $\mathrm{MgO}$ nanoparticles. J. Hazard. Mater. 2015, 299, 664-674. [CrossRef]

205. Jing, F.; Zou, L.; Wang, Y.; Li, B.; He, X.; Fan, Z.; Ren, Y.; Lv, Y.; Zhang, M.; Dan, C. Synthesis of high surface area, mesoporous $\mathrm{MgO}$ nanosheets with excellent adsorption capability for $\mathrm{Ni}(\mathrm{II})$ via a distillation treating. J. Colloid Interface Sci. 2015, 438, 259-267.

206. Umar, A.; Kumar, R.; Akhtar, M.S.; Kumar, G.; Kim, S.H. Growth and properties of well-crystalline cerium oxide $\left(\mathrm{CeO}_{2}\right)$ nanoflakes for environmental and sensor applications. J. Colloid Interface Sci. 2015, 454, 61-68. [CrossRef] [PubMed]

207. Anupriya, K.; Vivek, E.; Subramanian, B. Facile synthesis of ceria nanoparticles by precipitation route for UV blockers. J. Alloys Compd. 2014, 590, 406-410. [CrossRef]

208. Recillas, S.; García, A.; González, E.; Casals, E.; Puntes, V.; Sánchez, A.; Font, X. Use of $\mathrm{CeO}_{2}$, $\mathrm{TiO}_{2}$ and $\mathrm{Fe}_{3} \mathrm{O}_{4}$ nanoparticles for the removal of lead from water Toxicity of nanoparticles and derived compounds. Desalination 2011, 277, 213-220. [CrossRef]

209. Recillas, S.; Colón, J.; Casals, E.; González, E.; Puntes, V.; Sánchez, A.; Font, X. Chromium VI adsorption on cerium oxide nanoparticles and morphology changes during the process. J. Hazard. Mater. 2010, 184, 425-431. [CrossRef]

210. Mishra, P.K.; Saxena, A.; Rawat, A.S.; Dixit, P.K.; Rai, P.K. Surfactant-Free One-Pot Synthesis of Low-Density Cerium Oxide Nanoparticles for Adsorptive Removal of Arsenic Species. Environ. Prog. Sustain. Energy 2018, 37, 221-231. [CrossRef]

211. Ayawanna, J.; Teoh, W.T.; Niratisairak, S.; Sato, K. Gadolinia-modified ceria photocatalyst for removal of lead(II) ions from aqueous solutions. Mater. Sci. Semicond. Process. 2015, 40, 136-139. [CrossRef]

212. Ayawanna, J.; Sato, K. Photoelectrodeposition Effect of Lanthanum oxide-Modified Ceria Particles on the Removal of Lead(II) Ions from Water. Catal. Today 2017, 321-322, 128-134. [CrossRef]

213. Meepho, M.; Sirimongkol, W.; Ayawanna, J. Samaria-doped Ceria Nanopowders for Heavy Metal Removal from Aqueous Solution. Mater. Chem. Phys. 2018, 214, 56-65. [CrossRef]

214. Jiang, C.; Xiao, D.A. Nanosized Zirconium Dioxide Particles as an Efficient Sorbent for Lead Removal in Waters. Adv. Mater. Res. 2014, 926-930, 166-169. [CrossRef] 
215. Seisenbaeva, G.A.; Geoffrey, D.; Kessler, V.G.; Jean-Marie, N. General facile approach to transition-metal oxides with highly uniform mesoporosity and their application as adsorbents for heavy-metal-ion sequestration. Chemistry 2015, 20, 10732-10736. [CrossRef] [PubMed]

216. Yalçınkaya, Ö.; Kalfa, O.M.; Türker, A.R. Chelating agent free-solid phase extraction (CAF-SPE) of Co(II), $\mathrm{Cu}(\mathrm{II})$ and $\mathrm{Cd}(\mathrm{II})$ by new nano hybrid material $\left(\mathrm{ZrO}_{2} / \mathrm{B}_{2} \mathrm{O}_{3}\right)$. J. Hazard. Mater. 2011, 195, 332-339. [CrossRef] [PubMed]

217. Zhang, Q.; Jie, T.; Zhang, Z.; Nie, G.; Zhao, H.; Peng, Q.; Jiao, T. Unique and outstanding cadmium sequestration by polystyrene-supported nanosized zirconium hydroxides: A case study. RSC Adv. 2015, 5, 55445-55452. [CrossRef]

218. Hua, M.; Jiang, Y.; Wu, B.; Pan, B.; Zhao, X.; Zhang, Q. Fabrication of a new hydrous Zr(IV) oxide-based nanocomposite for enhanced $\mathrm{Pb}(\mathrm{II})$ and $\mathrm{Cd}(\mathrm{II})$ removal from waters. ACS Appl. Mater. Interfaces 2013, 5 , 12135. [CrossRef] [PubMed]

219. Hayati, B.; Maleki, A.; Najafi, F.; Daraei, H.; Gharibi, F.; Mckay, G. Synthesis and characterization of PAMAM/CNT nanocomposite as a super-capacity adsorbent for heavy metal $\left(\mathrm{Ni}^{2+}, \mathrm{Zn}^{2+}, \mathrm{As}^{3+}, \mathrm{Co}^{2+}\right)$ removal from wastewater. J. Mol. Liquids 2016, 224, 1032-1040. [CrossRef]

220. Hotze, E.M.; Phenrat, T.; Lowry, G.V. Nanoparticle aggregation: Challenges to understanding transport and reactivity in the environment. J. Environ. Qual. 2010, 39, 1909-1924. [CrossRef] [PubMed]

221. Tounsadi, H.; Khalidi, A.; Abdennouri, M.; Barka, N. Activated carbon from Diplotaxis Harra biomass: Optimization of preparation conditions and heavy metal removal. J. Taiwan Inst. Chem. Eng. 2016, 59, 348-358. [CrossRef]

222. Parlayici, S.; Eskizeybek, V.; Avc1, A.; Pehlivan, E. Removal of chromium(VI) using activated carbon-supported-functionalized carbon nanotubes. J. Nanostruct. Chem. 2015, 5, 255-263. [CrossRef]

223. Kang, A.J.; Baghdadi, M.; Pardakhti, A. Removal of cadmium and lead from aqueous solutions by magnetic acid-treated activated carbon nanocomposite. Desalinat. Water Treat. 2015, 3994, 1-17.

224. Jayaweera, H.D.A.C.; Siriwardane, I.; Silva, K.M.N.D.; Silva, R.M.D. Synthesis of multifunctional activated carbon nanocomposite comprising biocompatible flake nano hydroxyapatite and natural turmeric extract for the removal of bacteria and lead ions from aqueous solution. Chem. Central J. 2018, 12, 18. [CrossRef]

225. Fernando, M.S.; Silva, R.M.D.; Silva, K.M.N.D. Synthesis, characterization, and application of nano hydroxyapatite and nanocomposite of hydroxyapatite with granular activated carbon for the removal of $\mathrm{Pb}^{2+}$ from aqueous solutions. Appl. Surf. Sci. 2015, 351, 95-103. [CrossRef]

226. Salam, M.A.; Makki, M.S.I.; Abdelaal, M.Y.A. Preparation and characterization of multi-walled carbon nanotubes/chitosan nanocomposite and its application for the removal of heavy metals from aqueous solution. J. Alloys Compd. 2011, 509, 2582-2587. [CrossRef]

227. Xie, Y.; Qiang, H.; Liu, M.; Ke, W.; Wan, Q.; Deng, F.; Long, L.; Zhang, X.; Wei, Y. Mussel Inspired Functionalization of Carbon Nanotubes for Heavy Metal Ion Removal. RSC Adv. 2015, 5, 68430-68438. [CrossRef]

228. Cheng, Z.; Sui, J.; Jing, L.; Tang, Y.; Wei, C. Efficient removal of heavy metal ions by thiol-functionalized superparamagnetic carbon nanotubes. Chem. Eng. J. 2012, 210, 45-52.

229. Kosa, S.A.; Al-Zhrani, G.; Salam, M.A. Removal of heavy metals from aqueous solutions by multi-walled carbon nanotubes modified with 8-hydroxyquinoline. Chem. Eng. J. 2012, 181-182, 159-168. [CrossRef]

230. Mamba, G.; Mbianda, X.Y.; Govender, P.P.; Mamba, B.B.; Krause, R.W. Application of multiwalled carbon nanotube-cyclodextrin polymers in the removal of heavy metals from water. J. Appl. Sci. 2010, 10. [CrossRef]

231. Hayati, B.; Maleki, A.; Najafi, F.; Gharibi, F.; Mckay, G.; Gupta, V.K.; Marzban, N. Heavy metal adsorption using PAMAM/CNT nanocomposite from aqueous solution in batch and continuous fixed bed systems. Chem. Eng. J. 2018, 346, 258-270. [CrossRef]

232. Donat, R.; Akdogan, A.; Erdem, E.; Cetisli, H. Thermodynamics of $\mathrm{Pb}^{2+}$ and $\mathrm{Ni}^{2+}$ adsorption onto natural bentonite from aqueous solutions. J. Colloid Interface Sci. 2005, 286, 43-52. [CrossRef]

233. Eskandari, M.; Zakeri Khatir, M.; Khodadadi Darban, A.; Meshkini, M. Decreasing Ni, Cu, Cd, and Zn heavy metal magnetite-bentonite nanocomposites and adsorption isotherm study. Mater. Res. Express 2018, 5, 045030. [CrossRef]

234. Ma, J.; Su, G.; Zhang, X.; Huang, W. Adsorption of Heavy Metal Ions from Aqueous Solutions by Bentonite Nanocomposites. Water Environ. Res. 2016, 88, 741-746. [CrossRef] 
235. Alswata, A.A.; Ahmad, M.B.; Al-Hada, N.M.; Kamari, H.M.; Hussein, M.Z.B.; Ibrahim, N.A. Preparation of Zeolite/Zinc Oxide Nanocomposites for toxic metals removal from water. Results Phys. 2017, 7, 723-731. [CrossRef]

236. Zendehdel, M.; Shoshtari-Yeganeh, B.; Cruciani, G. Removal of heavy metals and bacteria from aqueous solution by novel hydroxyapatite/zeolite nanocomposite, preparation, and characterization. J. Iran. Chem. Soc. 2016, 13, 1915-1930. [CrossRef]

237. Lee, S.M.; Kim, W.G.; Laldawngliana, C.; Tiwari, D. Removal Behavior of Surface Modified Sand for Cd(II) and $\mathrm{Cr}(\mathrm{VI})$ from Aqueous Solutions. J. Chem. Eng. Data 2010, 55, 3089-3094. [CrossRef]

238. Kaşgöz, H.; Durmuş, A.; Kaşgöz, A. Enhanced swelling and adsorption properties of AAm-AMPSNa/clay hydrogel nanocomposites for heavy metal ion removal. Polym. Adv. Technol. 2010, 19, 213-220. [CrossRef]

239. Zhao, G.; Huang, X.; Tang, Z.; Huang, Q.; Wang, X.K. Polymer-based nanocomposites for heavy metal ions removal from aqueous solution: A review. Polym. Chem. 2018, 9, 3562-3582. [CrossRef]

240. Lu, F.; Astruc, D. Nanomaterials for removal of toxic elements from water. Coord. Chem. Rev. 2018, 356, 147-164. [CrossRef]

241. Manju, G.N.; Krishnan, K.A.; Vinod, V.P.; Anirudhan, T.S. An investigation into the sorption of heavy metals from wastewaters by polyacrylamide-grafted iron(III) oxide. J. Hazard. Mater. 2002, 91, 221-238. [CrossRef]

242. Rajakumar, K.; Dinesh, K.S.; Sivanesan, S.; Sai, R.L. Effective removal of heavy metal ions using $\mathrm{Mn}_{2} \mathrm{O}_{3}$ doped polyaniline nanocomposite. J. Nanosci. Nanotechnol. 2014, 14, 2937-2946. [CrossRef]

243. Afshar, A.; Sadjadi, S.A.S.; Mollahosseini, A.; Eskandarian, M.R. Polypyrrole-polyaniline $/ \mathrm{Fe}_{3} \mathrm{O}_{4}$ magnetic nanocomposite for the removal of $\mathrm{Pb}(\mathrm{II})$ from aqueous solution. Korean J. Chem. Eng. 2016, 33, 1-9. [CrossRef]

244. Cai, J.; Lei, M.; He, J.R.Z.; Chen, T.; Liu, S.; Fu, S.H.; Li, T.T.; Liu, G.; Fei, P. Electrospun Composite Nanofiber Mats of Cellulose@Organically Modified Montmorillonite for Heavy Metal Ion Removal: Design, Characterization, Evaluation of Absorption Performance. Compos. Part A 2017, 92, 10-16. [CrossRef]

245. Abhishek, K.; Meeta, G.; Jain, V.K. A novel reusable nanocomposite for complete removal of dyes, heavy metals and microbial load from water based on nanocellulose and silver nano-embedded pebbles. Environ. Technol. 2015, 36, 706-714.

246. Saad, A.H.A.; Azzam, A.M.; El-Wakeel, S.T.; Mostafa, B.B.; El-Latif, M.B.A. Removal of toxic metal ions from wastewater using ZnO@Chitosan core-shell nanocomposite. Environ. Nanotechnol. Monitor. Manag. 2018, 9, 67-75. [CrossRef]

247. Esmat, M.; Farghali, A.A.; Khedr, M.H.; El-Sherbiny, I.M. Alginate-Based Nanocomposites for Efficient Removal of Heavy Metal Ions. Int. J. Biol. Macromol. 2017, 102, 272-283. [CrossRef]

248. Gokila, S.; Gomathi, T.; Sudha, P.N.; Anil, S. Removal of the heavy metal ion chromiuim(VI) using Chitosan and Alginate nanocomposites. Int. J. Biol. Macromol. 2017, 104, 1459-1468. [CrossRef]

249. Lofrano, G.; Carotenuto, M.; Libralato, G.; Domingos, R.F.; Markus, A.; Dini, L.; Gautam, R.K.; Baldantoni, D.; Rossi, M.; Sharma, S.K. Polymer functionalized nanocomposites for metals removal from water and wastewater: An overview. Water Res. 2016, 92, 22-37. [CrossRef]

250. Jingfu, L.; Zongshan, Z.; Guibin, J.; Cuiling, R. Coating $\mathrm{Fe}_{3} \mathrm{O}_{4}$ Magnetic Nanoparticles with Humic Acid for High Effi cient Removal of Heavy Metals in Water. Environ. Sci. Technol. 2008, 42, 6949-6954.

251. Lü, T.; Qi, D.; Dong, Z.; Lü, Y.; Zhao, H. A facile method for emulsified oil-water separation by using polyethylenimine-coated magnetic nanoparticles. J. Nanopart. Res. 2018, 20, 88. [CrossRef]

252. Mirrezaie, N.; Nikazar, M.; Hasan Zadeh, M. Synthesis of Magnetic Nanocomposite $\mathrm{Fe}_{3} \mathrm{O}_{4} \mathrm{Coated}$ Polypyrrole (PPy) for Chromium(VI) Removal. Adv. Mater. Res. 2013, 829, 649-653. [CrossRef]

253. Zhang, W.; Shi, X.; Zhang, Y.; Gu, W.; Li, B.; Xian, Y. Synthesis of water-soluble magnetic graphene nanocomposites for recyclable removal of heavy metal ions. J. Mater. Chem. A 2013, 1, 1745-1753. [CrossRef]

254. Elmi, F.; Hosseini, T.; Taleshi, M.S.; Taleshi, F. Kinetic and thermodynamic investigation into the lead adsorption process from wastewater through magnetic nanocomposite $\mathrm{Fe}_{3} \mathrm{O}_{4} / \mathrm{CNT}$. Nanotechnol. Environ. Eng. 2017, 2, 13. [CrossRef]

255. Huang, L.; He, M.; Chen, B.; Hu, B. Magnetic Zr-MOFs nanocomposites for rapid removal of heavy metal ions and dyes from water. Chemosphere 2018, 199, 435-444. [CrossRef]

256. Ge, L.; Wang, W.; Peng, Z.; Tan, F.; Wang, X.; Chen, J.; Qiao, X. Facile fabrication of Fe@MgO magnetic nanocomposites for efficient removal of heavy metal ion and dye from water. Powder Technol. 2018, 326, 393-401. [CrossRef] 
257. Lu, Z.; Wang, X.Q.; Miao, Y.M.; Chen, Z.Q.; Qiang, P.F.; Cui, L.Q.; Jing, H.; Guo, Y.Q. Magnetic ferroferric oxide nanoparticles induce vascular endothelial cell dysfunction and inflammation by disturbing autophagy. J. Hazard. Mater. 2016, 304, 186-195.

258. Shen, Y.; Huang, Z.; Liu, X.; Qian, J.; Xu, J.; Yang, X.; Sun, A.; Ge, J. Iron-induced myocardial injury: An alarming side effect of superparamagnetic iron oxide nanoparticles. J. Cell. Mol. Med. 2015, 19, 2032. [CrossRef]

(c)

(C) 2019 by the authors. Licensee MDPI, Basel, Switzerland. This article is an open access article distributed under the terms and conditions of the Creative Commons Attribution (CC BY) license (http://creativecommons.org/licenses/by/4.0/). 